\title{
Urgências e Emergências em Saúde: perspectivas de profissionais e usuários
}

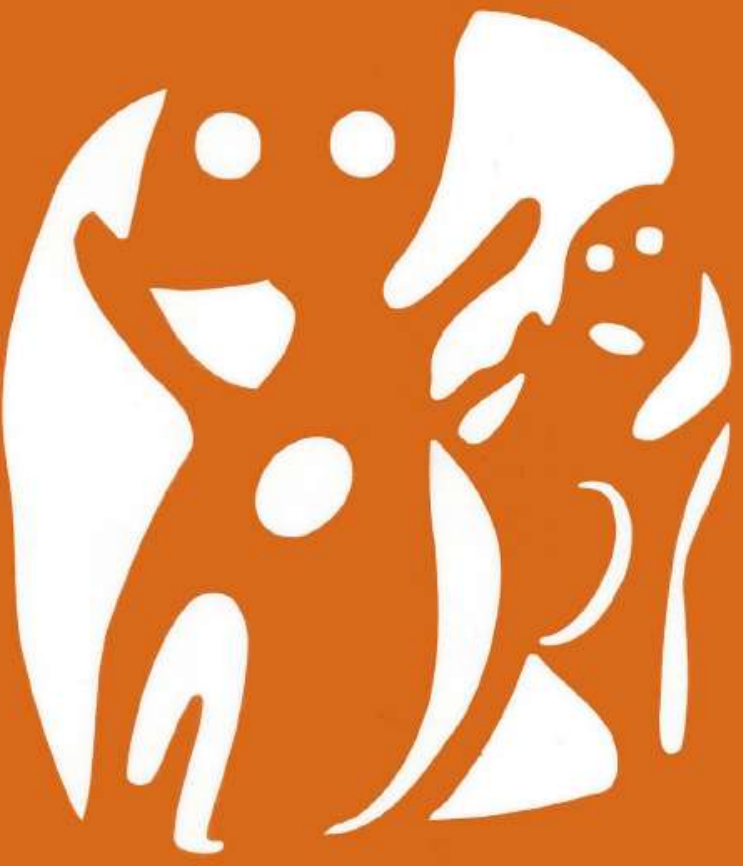

Armelle Giglio-Jacquemot 

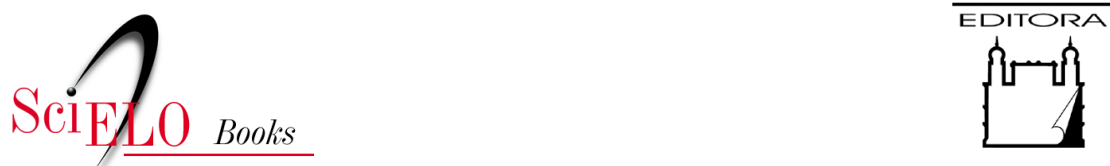

FIOCRUZ

\title{
Urgências e emergências em saúde perspectivas de profissionais e usuários
}

\author{
Armelle Giglio-Jacquemot
}

Aviso: Este arquivo foi atualizado dia 09/02/2021 para inclusão do Prefácio.

\section{SciELO Books / SciELO Livros / SciELO Libros}

GIGLIO-JACQUEMOT, A. Urgências e emergências em saúde: perspectivas de profissionais e usuários [online]. Rio de Janeiro: Editora FIOCRUZ, 2005, 143 p. Antropologia e Saúde collection. ISBN: 978-85-7541-378-4. https://doi.org/10.7476/9788575413784.

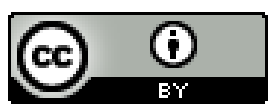

All the contents of this work, except where otherwise noted, is licensed under a Creative Commons Attribution 4.0 International license.

Todo o conteúdo deste trabalho, exceto quando houver ressalva, é publicado sob a licença Creative Commons Atribição 4.0.

Todo el contenido de esta obra, excepto donde se indique lo contrario, está bajo licencia de la licencia Creative Commons Reconocimento 4.0. 


\section{Urgências e Emergências em Saúde: perspectivas de profissionais e usuários}


FUNDAÇÃO OSWALDO CRUZ

Presidente

Paulo Marchiori Buss

Vice-Presidente de Ensino, Informação e Comunicação Maria do Carmo Leal

\section{EDITORA FIOCRUZ}

Coordenadora

Maria do Carmo Leal

Conselho Editorial

Carla Macedo Martins

Carlos E. A. Coimbra Jr.

Charles Pessanha

Gilberto Hochman

Jaime L. Benchimol

José da Roch a Carvalheiro

José Rodrigues Coura

Luis David Castiel

Luiz Fernando Ferreira

Maria Cecilia de Souza Minayo

Miriam Struchiner

Paulo Amarante

Paulo Gadelha

Vanize Macêdo

Coordenador Executivo

João Carlos Canossa P. Mendes

Coleção Antropologia e Saúde

Editores Responsáveis: Carlos E. A. Coimbra Jr.

Maria Cecília de Souza Minayo 


\section{Urgências e Emergências em Saúde: perspectivas de profissionais e usuários}

Armelle Giglio-Jacquemot 
Copyright $^{\oplus} 2005$ da autora

Todos os direitos desta edição reservados à

FUNDAÇÃo OSWALDO CRUZ / EDITORA

ISBN: 85-7541-059-8

Projeto Gráfico e Editoração Eletrônica:

Angélica Mello e Daniel Pose Vazquez

Capa:

Danowski Design

Ilustração da Capa:

A partir de desenho de Hans Arp, Dada Augrandair, 1921. Foundation Arp, Clamart.

Revisão e Copidesque:

Janaina de Souza Silva

Catalogação na fonte

Centro de Informação Científica e Tecnológica

Biblioteca da Escola Nacional de Saúde Pública Sergio Arouca

G459u Giglio-Jacquemot, Armelle

Urgências e Emergências em Saúde: perspectivas de profissionais e usuários. / Armelle Giglio-Jacquemot. Rio de Janeiro: Editora FIOCRUZ, 2005.

144 p., tab., mapas (Coleção Antropologia e Saúde)

1. Serviços médicos de emergências. 2. Determinação de necessidades de cuidados de saúde. I. Título.

CDD - 20.ed -362.1

2005

EDITORA FIOCRUZ

Av. Brasil, 4036 - $1^{2}$ andar - sala 112 - Manguinhos

21040-361 - Rio de Janeiro - RJ

Tels: (21) 3882-9039 e 3882-9041

Telefax:(21)3882-9006

e-mail: editora@fiocruz.br

http://www.fiocruz.br

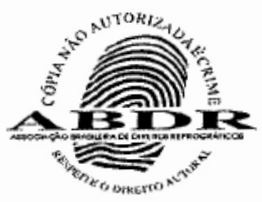


A Tadeu. 



\section{SUMÁRI0}

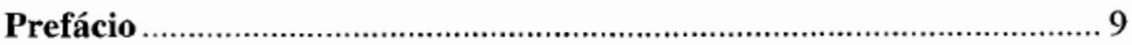

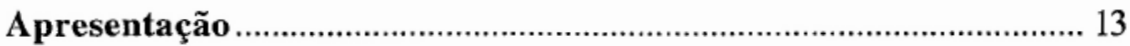

1. Definições de Urgência e Emergência: critérios e limitações ................. 19

2. Método, Locais e Caminhos da Pesquisa .............................................. 31

3. Etnografia da Triagem ...................................................................... 45

4. "Tem Fratura Exposta? Artéria Babando?":

a perspectiva dos profissionais da saúde ............................................. 57

5. “Pode Esperar? Dá para Agüentar?":

a perspectiva dos seguranças, porteiros e recepcionistas..................... 75

6. "Será que É? Será que Não É?":

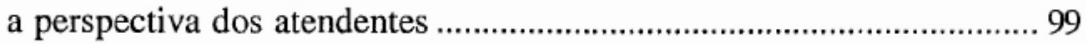

7. “Agora Não Tem Mais Condições, Eu Não Agüento Mais!”:

a perspectiva dos usuários ........................................................... 121

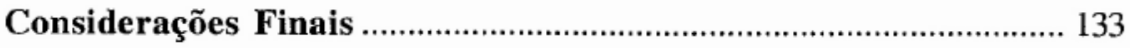

Referências Bibliográficas ........................................................ 137

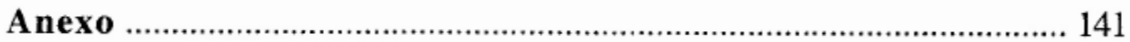





\section{Prefácio}

Hilda Hilst, poeta, em entrevista no ano de 1997, comentava "que sempre foi péssima em matemática":!

Quando eu era menina, tinha tanta mania de perguntar que era uma coisa absurda... As freiras, onde eu estudava, ficavam desesperadas. A que ensinava aritmética chegava e dizia:

- Tenho três galinhas. Uma, enquanto estava caminhando se perdeu. A outra morreu. Quantas galinhas sobraram?

Aí eu comę̧ava:

- Mas porque a galinha morreu? E a outra? Como perdeu? Como é que alguém perde uma galinha? Mas quem estava tomando conta delas não sabe dar explicações!

Aí criava uma situação!

A freira respondia:

- Não precisa saber o porquê!

Eu queria a história desta galinha perdida, morta...

Armelle Giglio-Jacquemot, tal como Hilda Hilst, pergunta e busca o como e os porquês. Respostas. $\mathrm{O}$ que é uma urgência? Como reconhecer o que é urgente? Como são os bastidores, palco e atores na assistência às urgências? Como alguém pode perder o caminho para os serviços de urgência? Como alguém morre esperando o atendimento? Como as pessoas não percebem a urgência verdadeira? Mulheres não enfartam, tem 'piripaque'e 'piti'? Os perdidos no caminho, os mortos e os sobreviventes eram todos portadores de urgência?

A urgência 'espiritual' na umbanda foi o que levou a autora deste livro, a fazer aqui no Brasil, sua tese de doutorado, buscando entender os longos e tortuosos caminhos percorridos pelas pessoas para compreenderem: por que adoeci? Como adoeci? E do quê? Por que eu? Por que agora? As respostas encontradas muitas vezes não apontavam para a dimensão biológica da doença, às vezes ausente principalmente nas relações sociais fragilizadas, enfraquecidas, desequilibradas, rompidas.

' HILST, H. Entrevista. O Estado de S. Paulo, 31 maio 1997. Caderno 2, página D7. 
Optando pela antropologia da saúde, Armelle terminou desvelando urgências sociais, religiosas, econômicas, familiares, amorosas, políticas, urgências de cidadania, dentre todas a mais freqüente, a mais constante, a da saúde. O primeiro trabalho da autora, ainda não publicado no Brasil, Guides et Médiums au secours des Hommes, deixou-a sensibilizada para este segundo. Cruzar o Atlântico foi rotina nos dois temas.

A proposta do estudo sobre urgência médica nasceu do encontro de dois cientistas tocados, incomodados, inconformados com o "não precisa saber o porquê" daqueles que trabalham nas urgências. $O$ segundo cientista é o médico anestesiologista francês, responsável à época por intercâmbios e cooperações técnicas internacionais do Service d'Aide Médicale Urgente (Samu) de France, incluindo o Brasil, Miguel Martinez Almoyna. Profissional apaixonado e provocador, durante anos convivendo com a dúvida do que era 'urgência' na França e nas dezenas de países dos quatro continentes, vibrante debatedor, educador e difusor da necessidade de construção de Serviços de Urgência Pré-Hospitalar. Ardoroso defensor da Atenção às Urgências como parte da organização do sistema de saúde pública, também o incomodava a pergunta sem resposta "o que era urgência?", mas não acreditava ser possível que os profissionais da saúde estivessem capacitados para dar esta resposta, acreditava que o estudo deveria ser feito por um antropólogo ou cientista social.

Por conta das preocupações comuns nascidas de diferentes experiências, Armelle e Martinez conversaram, discutiram e, pela afinidade dos dois com o Brasil aqui foi o campo de trabalho escolhido. Esta decisão, porém, não significou facilidade. Armelle foi à luta e assim como as pessoas a caminho das unidades de urgência encontrou muitas 'catracas', barreiras e acessos negados.

Seu trabalho nos mostra a partir de personagens e de olhares divergentes a urgência todo o tempo sendo anunciada como 'verdadeira' ou 'falsa'. A arrogância, a lógica do "você sabe com quem está falando?", de DaMatta, dos dois lados das portas dos prontos-socorros. Alguns poucos pacientes eram portadores de privilégios, recusavam a cidadania como nos ensinou Milton Santos. A maioria, no entanto, se sentia como alguém agraciado com a clemência dos serviços de saúde. Outros, por não encontrarem nenhum 'pronto-socorro de cidadania' ou 'social', buscavam a medicalização de suas angústias e problemas nos serviços de saúde.

O que transforma uma crise, uma dor, uma angústia, um problema em urgência para os leigos e os diferentes profissionais envolvidos? Afinal, participam o protagonista, a família, amigos, vizinhos, testemunhas anônimas, a segurança pública com os bombeiros, policiais civis e militares, a guarda municipal, o segurança da porta da unidade de urgência, a recepcionista que preenche a ficha, a faxineira - se o paciente é seu conhecido, vizinho ou parente -, auxiliares de enfermagem, enfermeiros, estudantes de enfermagem e medicina, médicos, técnicos de radiologia, de laboratório, assistentes sociais, motoristas de ambulância, telefonistas, gerentes e gestores... Com certeza devo ter esquecido mais algumas personagens.

"Isto não é uma urgência de saúde, uma urgência médica". A certeza, a forma categórica como é dita, é motivo de conflito dia e noite, por incrível que pareça, não só no Brasil. Martinez coloca tal postura dos profissionais de saúde como um problema na França; em proporções diferentes, o consenso não existe. Lembro de um debate com 
Davi Capistrano da Costa Filho - importante sanitarista que perdemos não há muito tempo - comentando sobre Cuba que, nos tempos áureos do seu sistema de saúde, apesar de o médico de família do quarteirão, das policlínicas e de todo os outros recursos, as unidades de urgência continuavam sendo procuradas por "casos não urgentes".

Ignorância da população? A dor velha vira urgência no domingo à tarde justo na hora do futebol? As febres da manhã das crianças só são urgentes a $1 \mathrm{~h}$ da manhã? Agravam as dores apenas para conseguir uma carona de ambulância ou atestado médico? A presença de sangue é prenúncio de urgência? A doença é de "posto ou de hospital", quem sabe a resposta? Em contrapartida, pessoas aparentemente invisiveis com suas dores, falta de ar, o medo, a aflição com contornos aparentemente tão claros, percebidos, às vezes, por raros e sensíveis olhos de uma recepcionista, de um segurança, que tenta dar visibilidade a este portador abandonado nas salas de espera ou em macas, tal qual jornal velho com notícias que não contam mais nada da vida.

A esta guerra declarada, Armelle testemunhou, conviveu, ouviu, viu, observou, enxergou os invisíveis, conversou, perguntou, acompanhou ao telefone. Na ambulância, na casa, na rua, na portaria das unidades de urgência, no balcão de preencher 'ficha', na sala de espera, nos corredores internos do pronto-socorro, na sala de repouso de médicos e estudantes de medicina, na sala de urgência, com um cuidado e preocupação ética todo o tempo, respeitando hierarquias, vencendo distâncias, as barreiras, e muitas vezes mordendo os lábios para não proclamar sua indignação. Várias vezes ouvi em primeira mão as histórias presenciadas e os porquês carregados de angústia. Discutia o modelo assistencial, a formação dos profissionais, a exclusão, o preconceito, mas, de fato, aliviar a aflição era muito dificil para quem havia sido testemunha de tantas 'urgências'.

Aflição que não é nova. Em 1885, Anton Tchekhov - médico da Rússia czarista em um conto, justamente intitulado "Aflição"- fala da saga de um excluído trabalhador rural, um mugique, levando a esposa ao hospital e imaginando a cena a ser enfrentada quando lá chegasse. Enquanto conduz, na neve, sua mulher, resmunga, como contando a ela o que vai acontecer, vai fazer o médico:

(...) começara a xingar. - Como? Que foi isso. Vai gritar, - Por que chega fora de hora? Pensa que eu sou algum cachorro, para me ocupar de vocês, diabos, o dia inteiro? Por que não chegou de manhã? E eu vou dizer: - Senhor doutor! Pável Ivânich! Vossa Alta Nobreza! E mais adiante o médico dirá: - Conheço vocês! Sempre arranjam uma desculpa. ${ }^{2}$

Outro dilema: qual é à hora da urgência? O paciente veio cedo demais, veio por bobagem, veio tarde demais, não há nada mais que possa ser feito... Quando escuto queixas dos alunos a respeito do "desespero das mães" por qualquer bobagem no pronto-socorro da pediatria, dou como tarefa perguntarem a suas próprias mães como reagiram quando o filho mais velho fez o primeiro 'talho' no couro cabeludo, se diante do sangramento elas não tinham certeza absoluta da possivel morte do filho.

2 TCHEKHOV, A. “A Dama do cachorrinho”. São Paulo: Ed.34, 1999. p. 66-72. 
Armelle Giglio-Jacquemot percorre todos os caminhos, das urgências silenciosas, da cinematografia das urgências traumáticas, do aluguel atrasado, procurando no pronto-socorro entrada e saida. Acompanha, observa todos os envolvidos, a solidariedade, o carinho, a irritação, a raiva, maus-tratos, negação, sinais, interações, comportamentos. Presencia alguns salvo-condutos, o sangue, a chegada via bombeiros, barreiras imensas aos alcoólatras, portadores de doença mental e pobres que se acham portadores de direitos, uma ousadia.

Os profissionais de saúde são os vilões deste estudo? Não é desta premissa que parte a autora, eles contam e debatem seus conceitos, suas dificuldades. Os profissionais de saúde são formados não em claustros fechados à realidade, mas tendo como referência natural e classificado como padrão de normalidade o secular processo de exclusão. A falta de crítica não justifica a intolerância a certas camadas da população, mas aponta a memória elitista e o sonho liberal ainda presente na profissão - a saúde é um direito social no Brasil somente a partir da Constituição de 1988.

Armelle faz parte do grupo de intelectuais franceses tocados por uma sensibilidade, uma brasilidade, onde se sentem irmanados para junto conosco descobrirem nosso jeito de ser, nossas singularidades e o universal. Parceria iniciada desde a missão francesa dos tempos de Dom João VI, renovada, apaixonada, incorpora no europeu fímbrias tropicais. Neste trabalho, a autora nos coloca diante de uma realidade nossa e também universal, na poesia de Britto "a realidade é coisa delicada, de se pegar com as pontas dos dedos". ${ }^{3}$

Todos nós, envolvidos com as diferentes urgências do ser humano, precisamos conhecer as suas muitas faces, procurar entender nosso papel ou nossos papéis como profissionais e cidadãos, nossas responsabilidades; portanto, este é um livro necessário, para explorarmos nosso cotidiano como trabalhadores da saúde, cientistas sociais, antropólogos, gerentes e gestores de serviços de saúde, como protagonistas ou testemunhas de crises desencadeadas pelas urgências. Em tempo, incluiria também os profissionais da imprensa, de todas as mídias.

Obrigada, Armelle, pela oportunidade de perguntarmos, como Hilda Hilst, pelos perdidos: como se perderam? Pelos mortos: como morreram? Pelos sobreviventes: como conseguiram?

Maria Cecilia Cordeiro Dellatorre Médica sanitarista, docente de Saúde Coletiva da Faculdade de Medicina de Marilia (Famema)

3 BRITTO, Paulo H. Macau. São Paulo: Companhia das Letras, 2003. 


\section{Apresentação}

Sobre prontos-socorros se conhece sobretudo a opinião de críticos. Profissionais da mídia - escrita e visual - apontam para as situações problemáticas nas quais se encontram essas unidades hospitalares: superlotação, escassez de recursos humanos e materiais, inadequação entre a oferta e a demanda de cuidados médicos de urgência.

Por sua vez, atores do atendimento às urgências e emergências (profissionais, agentes e administradores da saúde, responsáveis pelas políticas sanitárias) lastimam o fato de os prontos-socorros enfrentarem uma demanda que os afastam de sua missão declarada, pois acabam atendendo situações de saúde que, na sua maioria, não exigem atendimento médico urgente.

Diante desses problemas, denunciados com freqüência há anos, foi-se construindo um discurso, elaborado pelas autoridades sanitárias, por profissionais da saúde e reproduzido pela mídia, que acusa a população de fazer mau uso dos prontos-socorros e a designa como a grande responsável pela sobrecarga dessas unidades e pela desvirtuação da sua função. Os usuários não sabem o que é urgente; consultam no pronto-socorro e chamam a ajuda móvel de urgência para 'qualquer coisa'; cada um espera que seu caso seja rapidamente resolvido; a lógica da triagem escapa à maioria deles; a noção de 'bom uso' dos prontos-socorros é mal compreendida e mal aceita pelos doentes e suas famílias.

Tal discurso não é comum somente no Brasil. Em suas grandes linhas, ele também é bastante difundido em outros países, cujas realidades socioeconômicas e culturais são bem diferentes, tais como, por exemplo, na Espanha (Allué, 1999), na França (Peneff, 1992, 2000; Jacquemot, 2000), no Canadá (Burnett \& Grover, 1996), nos Estados-Unidos (Grumbach et al., 1993; Gill \& Riley, 1996). Ele também não é novo: certas referências relativas à inadequação da demanda de atendimento às urgências e emergências, cuja literatura médica está repleta, remontam a mais de 150 anos (Hodgson apud Padgett \& Brodsky, 1992). Para melhorar o quadro, seria, então, necessário educar a população de tal maneira que venha a aderir à lógica do 'bom uso' dos prontossocorros e os procure para problemas de saúde de sua competência específica, isto é, prestar atendimento de urgência aos que 'não podem esperar'. Entre outros objetivos, programas de educação para o público devem visar a informá-lo sobre os sintomas e acidentes que, entre os mais comuns, justificam a ida ao pronto-socorro e a chamada de um veículo de socorro; e os que, apesar do seu caráter às vezes espetacular, não exigem uma intervenção médica imediata.

Os usuários dos prontos-socorros e solicitantes da ajuda móvel de urgência também participam desse concerto de apreciações desfavoráveis. Suas reclamações dizem respeito geralmente à qualidade humana e técnica do atendimento, à demora a 
qual ficam submetidos até consegui-lo. Sentindo-se ignorados e até anulados pela falta de atenção/consideração dada ao seu sofrimento físico e moral, negados na apreciação íntima que tinham da gravidade do seu problema (ou de outrem, ente querido, conhecido), muitos são os que, resignados ou indignados, ao contarem sua má experiência com pronto-socorro ou central de chamadas, acabam colocando em questão a boa vontade, a competência e até a humanidade dos profissionais que (não) os atenderam. Claro que essa não é a reação, nem a vivência, dos usuários que recebem um atendimento correspondente à sua expectativa: entre eles, os que já estão preparados para esperar bastante - pois avaliaram que o seu problema não é tão urgente assim -; também os que, ao receber um atendimento rápido, vêem sua inquietação levada em consideração e sua apreciação de urgência confirmada pelos profissionais que lhes dão a atenção esperada.

Em sua avaliação negativa dos prontos-socorros, profissionais da saúde e usuários responsabilizam uns aos outros, em um face a face que testemunha, antes de tudo, o descompasso existente entre as respectivas expectativas. A questão de saber se as críticas dos primeiros aos segundos (e vice e versa) são legítimas não interessa muito, pois leva a resultados sem surpresas, já que os argumentos e as razões dos profissionais da saúde e dos usuários são elaborados a partir dos critérios e da lógica que fundamentam o 'seu' ponto de vista. Em outros termos, uns e outros estão certos, isto é, razoavelmente levados a colocar em questão a validade e a pertinência de comportamentos e discursos julgados errados, ou absurdos, por serem justamente a expressão de um ponto de vista diferente e até mesmo incompatível com o seu.

Revela-se bem mais interessante e estimulante adotar uma postura distanciada e compreensiva, que não pretenda olhar para as críticas e queixas com o intuito de avaliálas, no sentido de julgar o certo e o errado, mas sim com a preocupação de entender o que está por trás delas, isto é, de que fenômenos imediatamente inacessíveis ao entendimento elas podem ser a expressão mais visível e audível.

A hipótese aqui levantada é que o descompasso manifesto entre as expectativas dos especialistas legítimos da urgência e dos seus leigos pacientes traduz a existência, entre eles, de um desentendimento profundo que se origina no encontro de suas percepções, diferentes, da urgência médica. Ora, esse encontro não é simples 'desencontro'. Remete mais a um confronto e, ao considerar a insatisfação e até a exasperação que chega a provocar, é certamente mais justo falar em conflito ou, ainda, em choque de percepções. Em seus aspectos mais manifestos e associado a outros fatores agravantes, esse encontro desemboca em confrontações tensas ou violentas entre profissionais e solicitantes da ajuda médica de urgência, bem como em um tratamento às vezes indigno dos pacientes (Deslandes, 2002).

Essa hipótese, pouco ousada numa perspectiva antropológica, é sugerida por um fato bastante comprovado e explorado por essa disciplina, a saber, que a doença e a saúde têm uma realidade independente de suas definições biomédicas e são objetos de representações e práticas diversas que variam segundo as sociedades e, ainda dentro dessas, segundo os segmentos sociais e culturais que as compõem. A realidade biológica da doença, tal como identificada pelo especialista legítimo em atestar sua existência - o médico - não corresponde à realidade de quem sofre da doença. Ou, dito de 
maneira lapidar, a doença do doente (illness) não é a do médico (disease) (Fabrega, 1971; Einsenberg, 1977; Young, 1982). Entre as duas existe uma importante distorção: a primeira diz respeito à vivência individual da doença, à percepção de uma perturbação pelo sujeito, à experiência de algo anormal (dor, sofrimento, mal estar) enquanto a segunda refere-se aos estados orgânicos e funcionais e remete a um estado de alteração do organismo objetivamente comprovado. De ordem anatomofisiológica para o médico, a doença se constitui, para seu paciente, em um "evento psicológico e social" (Laplantine, 1992: 247). Importa ressaltar, aliás, que illness não é sempre uma resposta à disease e pode muito bem "existir sem o suporte da realidade fenomenológica da doença" (Fainzang, 1989: 54). Esta não precisa existir do ponto de vista do médico para ser vivida e representada pelo doente (sua família, seu grupo etc.). Porém, quando o indivíduo sofre de um mal que não se enquadra nas nosografias médicas vigentes, ele tem muita chance de não receber alívio nem reconhecimento social de seu estatuto de doente.

$E$ se ao falar de urgência e emergência médicas, recorresse-se a noções cujos conteúdos também diferem segundo a perspectiva e a situação de quem as usa?

Se uma parte importante das pessoas que vão para os prontos-socorros ou que chamam as centrais de urgência acham que o seu caso (ou o de alguém) é urgente no momento em que os profissionais da saúde pensam o contrário, é porque certamente solicitantes e profissionais têm uma percepção muitas vezes diferente da urgência/ emergência. E aí, não é que 'o povo é ignorante', 'não sabe o que é urgente', como é comum ouvir dos especialistas que atuam na área da urgência/emergência que, com esses comentários, tiram dos leigos usuários qualquer entendimento do que pode ser uma 'urgência/ emergência'. Simplesmente é mais provável que 'o povo' não compartiThe a mesma concepção técnica, biomédica, da urgência. Dessa, é bem possível que ele seja em parte ignorante. Mas nem por isso deixa de haver representações da urgência que os profissionais da urgência ignoram.

Partindo da premissa de que a apreciação que leva a identificar a urgência se baseia em diversos sinais e representações possíveis, variáveis em função dos contextos, dos universos de referência e de significações, considera-se, então, a urgência como uma questão de ponto de vista e de leitura informados a partir de critérios diferentes, embora, na perspectiva antropológica, igualmente legítimos. Isso, mesmo se, enquanto profissionais da urgência e da emergência, os atores do sistema biomédico encarregados da organização $\mathrm{e}$ do atendimento às urgências médicas estimam deter a concepção e a definição exatas dessas noções e a apreciação igualmente exata das situações ou estados por eles qualificados de 'urgência/emergência reais'.

A proposta do livro é desvendar o que é uma 'urgência' no domínio da saúde a partir de duas grandes perspectivas que manifestadamente não se recobrem, a dos usuários da rede pública de atendimento às urgências/emergências e a dos profissionais que nela atuam, esperando assim contribuir para um melhor entendimento das representações leigas e biomédicas da urgência e, por conseqüência, das percepções, concepções e práticas que nelas se embasam.

As definições da urgência e da emergência propostas nos textos médicos e de saúde pública, assim como as representações e práticas dos profissionais que atuam 
na área, remetem a concepções da urgência em saúde que nos interessa investigar, comparando-as mais especificamente com as dos pacientes que recorrem aos serviços propostos por essa rede.

Pela denominação 'profissionais da urgência/ emergência', importa deixar claro que não se designa somente os profissionais de saúde que trabalham na área da urgência/emergência - aos quais prefere-se atribuir a denominação de 'especialistas da urgência' -, mas todos os profissionais que, com ou sem formação médica, estão envolvidos no sistema público de atendimento biomédico à urgência/emergência, ou seja, todos os que são atores implicados, cada um no seu nível e segundo sua função, na resposta concreta fornecida por esse sistema: tanto médicos e enfermeiras quanto funcionários de prontos-socorros e centrais de chamadas, seguranças, porteiros, recepcionistas, atendentes, motoristas de veículos de socorro. Pois, apesar de esses últimos não terem recebido formação médica, eles atuam de maneira muito significativa no atendimento, na avaliação e na triagem dos pacientes.

A formulação da proposta não deve deixar inferir que se pressupõe a homogeneidade das representações e práticas da urgência por parte de cada categoria de atores: usuários e profissionais da urgência. Bem ao contrário, já que a própria diversidade social, cultural e de formação existente entre estes leva a supor, de antemão, que elas podem ser bastante heterogêneas.

Como 'emergência', 'urgência' e 'urgente', consideram-se as situações, estados, problemas que os sujeitos - médicos e não-médicos - avaliam como tal, independente de essa avaliação ser ou não confirmada por um diagnóstico médico. Seria muito equivocado, do ponto de vista antropológico, adotar a acepção biomédica da 'urgência' como referência implícita na investigação dessa noção, uma vez que esta também se converte aqui em objeto de investigação. As urgências dos pacientes e as dos profissionais são examinadas com o mesmo olhar crítico e a mesma ignorância curiosa a priori: são igualadas na medida em que representam, para o antropólogo, perspectivas diversas.

O primeiro capítulo examina as definições normativas da urgência e da emergência com o intuito de, em uma perspectiva crítica, analisar seu conteúdo e identificar os critérios discriminantes que, do ponto de vista biomédico, as caracterizam. Além disso, são apresentados, no segundo capítulo, o contexto e o desenvolvimento da pesquisa: descrevem-se os diversos locais da investigação e a metodologia utilizada, isto é, partese de uma observação participante realizada por ocasião de um trabalho de campo efetuado de 1998 a 1999, em Marília, cidade do interior de estado de São Paulo.

O terceiro capítulo abre o conjunto das análises construídas a partir dos dados etnográficos. A partir da descrição e do exame dos percursos seguidos pelos usuários até conseguirem um atendimento no pronto-socorro, procura-se identificar os profissionais que atuam de maneira significativa, e até decisiva, na triagem dos pacientes. Examina-se o papel crucial que desempenham suas avaliações e decisões e também outros fatores a este papel intimamente ligados, que têm incidências sobre $o$ atendimento dos pacientes.

A partir de então, os capítulos seguintes enfocam a questão das representações da urgência médica por parte dos vários atores implicados: médicos, seguranças, porteiros, recepcionistas, atendentes das centrais de chamada e usuários. Com base na 
observação de suas práticas, tenta-se apreender, em uma perspectiva comparativa, as concepções que têm 'do que é urgente', e procura-se identificar elementos de apreciação que informam de maneira significativa suas avaliações e decisões.

Não poderia deixar de agradecer à Fundação de Amparo à Pesquisa do Estado de São Paulo (Fapesp) e à Universidade Estadual Paulista (Unesp) que viabilizaram a realização da pesquisa. Também sou grata à Faculdade de Medicina e ao Hospital das Clínicas de Marília que me deram acesso ao campo.

Toda minha gratidão aos profissionais e usuários do pronto-socorro, da Central de Ambulâncias e do Resgate, às professoras e aos alunos do Departamento de Medicina Preventiva que me acolheram, compartilharam comigo opiniões, esperanças e indignações e me deram parte de seu tempo.

Desejo ainda agradecer à Université de Lille 3, à UFR IDIST e ao Groupe de Recherche sur les Actions et les Croyances Collectives, a concessão de afastamentos e financiamentos que me permitiram terminar o trabalho de campo no Brasil.

Finalmente, devo um agradecimento especial à professora e amiga Maria Cecília Cordeiro Dellatorre pela confiança que sempre me manifestou, pela força que me deu e por nossas conversas que foram de extrema valia. 



\section{Definições de Urgência e Emergência: critérios e limitações}

'Urgência' e 'emergência' possuem várias acepções na língua portuguesa e ainda outras na linguagem da biomedicina brasileira, que procura lhes atribuir um sentido unívoco e operante, propriamente médico. Antes de investigar as noções de urgência e emergência a partir das falas e observações recolhidas no campo, vejamos como são definidas de maneira normativa: primeiro no dicionário e, depois, em textos da literatura biomédica e de saúde pública.

\section{As Definiçõess do DicioníRio}

\section{O Dicionário Aurélio (1986) define da seguinte maneira 'urgência', 'urgente' e 'urgir':}

Urgência. (do lat. urgentia) S. f. 1. Qualidade de urgente 2. Caso ou situação de emergência, de urgência ." Urgência urgentíssima. Na linguagem legislativa, urgência extraordinária.

Urgente. (do lat. urgente) Adj. 2 g. 1. Que urge; que é necessário ser feito com rapidez. 2. Indispensável, imprescindível. 3. Iminente, impendente.

Urgir. (do lat. urgere) V. int. 1. Ser necessário sem demora; ser urgente (...) 2. Estar iminente; instar (...) 3. Não permitir demora (...) 4. Perseguir de perto; apertar cerco de. 5. Tornar imediatamente necessário; exigir, reclamar, clamar (...) 6. Insistir, instar (...). 7. Obrigar, impelir (...).

Enquanto designa um 'caso' ou uma 'situação' (2), a 'urgência' não é distinguida da 'emergência': no dicionário, a segunda entra na própria definição da primeira, como uma palavra de significação equivalente. No que diz respeito à urgência como 'qualidade de urgente' (1), a definição aponta para dois critérios que conferem essa qualidade: o fator tempo (a rapidez) e o fator necessidade (precisa ser feito). 
As definições de 'emergência' (1986) não indicam esses critérios:

Emergência. (do lat. emergentia) S.f. 1. Ação de emergir. 2. Nascimento (do Sol). 3. Situação crítica; acontecimento perigoso ou fortuito; incidente. 4. Caso de urgência, de emergência: emergências médicas; emergências cardíacas 5 . Morf. Veg. Produção da superficie de um órgão vegetal em cuja formação entram elementos celulares subepidérmicos (...) 6. Biol. Ger. Excrescência de uma parte, que não forma órgão definido. 7. Bras., NE. Pop. Discussão acesa; altercação (...).

Emergente. (do lat. emergente) Adj. 2 g. 1. Que emerge. 2. Que procede ou resulta. (...).

Emergir. (do lat. emergere) V. int. 1. Sair de onde estava mergulhado (...) 2. Manifestar-se, mostrar-se, patentear-se (...) 3. Elevar-se com se saísse das ondas (...) 4. Fazer sair de onde estava mergulhado (...). (grifos do dicionário)

A palavra 'emergência', quando aplicada a um 'caso', não é dissociada da palavra 'urgência' (4). Como na definição de 'urgência', as duas palavras são apresentadas como sinônimas. É interessante notar que o dicionário empresta seu exemplo a um uso biomédico do termo - 'emergências médicas, emergências cardiacas'-para ilustrar essa acepção da palavra, no momento em que a literatura biomédica insiste justamente na distinção a ser feita entre 'as urgências' e 'as emergências', como será descrito mais adiante.

Enquanto a urgência é definida como qualidade de urgente, a emergência é definida como ação de emergir. Uma emergência é o surgimento de 'alguma coisa': ela ć um acontecimento. A definição introduz critérios que caracterizam essa ocorrência: o caráter repentino e imprevisto de sua manifestação, assim como o seu caráter crítico e perigoso (3). Esses critérios estão ausentes na definição da 'urgência'.

Em resumo, o dicionário não indica qualquer distinção entre um 'caso (situação) de urgência' e um 'caso (situação) de emergência'. Portanto, referindo-se a elementos gerais propostos pelas definições, a urgência e a emergência aparecem caracterizadas da seguinte maneira:

- a urgência é alguma coisa que exige uma ação rápida e indispensável. A definição não aponta para qualquer caráter de gravidade, de risco, de perigo.

- a emergência é o acontecimento de alguma coisa séria, cuja aparição súbita causa ou ameaça perigo. A definição não aponta para qualquer necessidade de ação rápida.

\section{As Definiçófes Biomédicas}

No nível dos discursos, os profissionais de saúde que atuam no domínio da urgência referem-se, com frequêencia, à distinção entre urgência e emergência e insistem também na importância de saber a diferença entre as duas para agir de maneira adequa- 
da. Assim, frases muito comuns pronunciadas por eles - tais como: "o povo' acha tudo urgente", "o povo não sabe fazer a diferença", "confunde urgência e emergência" indicam implicitamente a existência de critérios discriminantes (qualificados por eles de "técnicos" ou ainda de "objetivos") que permitem reconhecer e classificar, como tal, o que chamam de "verdadeira urgência", "verdadeira emergência".

A intenção deste capitulo é examinar as definições biomédicas de urgência e de emergência, no intuito de discernir quais as características gerais apresentadas por casos ou situações, que, do ponto de vista biomédico normativo, devem ser considerados 'urgência' ou 'emergência', e que os diferenciam dos que não estão inseridos nessas duas categorias de problemas, ou situações de saúde.

Essas categorias existem a ponto de justificar a existência de serviços especializados, nos hospitais destinados, na ótica biomédica, ao atendimento das 'urgências' e 'emergências'. Elas existem a ponto de justificar uma ordem de prioridade no atendimento. Então, como a literatura biomédica acadêmica as define? Quais são os critérios relevantes por ela apontada?

Referindo-se às definições propostas por Aranha (1969) e Lopez (1979), Jairnilson Silva Paim, professor adjunto do Departamento de Medicina Preventiva da Universidade Federal da Bahia (Ufba), propõe definições de 'urgência' e 'emergência' representativas das que foram encontradas, com formulações similares, em outros textos. No artigo "Organização da atenção à saúde para a urgência/emergência" (1994: 152), ele escreveu:

Uma emergência corresponde a um 'processo com risco iminente de vida, diagnosticado e tratado nas primeiras horas após sua constatação'. ${ }^{2}$ Exige que o tratamento seja imediato diante da necessidade de manter funções vitais e evitar incapacidade ou complicações graves. Representa situações como choque, parada cardíaca e respiratória, hemorragia, traumatismo crânio-encefálico etc.

Já a urgência significa 'um processo agudo clínico ou cirúrgico, sem risco de vida iminente'. ${ }^{3}$ Nesse caso há risco de evolução para complicações mais graves ou mesmo fatais, porém, não existe um risco iminente de vida. Representa situações como fraturas, feridas lácero-contusas sem grandes hemorragias, asma brônquica, transtornos psiquiátricos, etc.

Em sua caracterização, o autor acrescenta mais uma categoria de situações, ou problemas de saúde, que designa como sendo 'de rotina' por não apresentarem 'riscos de vida'. Entre essas situações e problemas de saúde, convém distinguir os que justificariam um 'pronto-atendimento':

(...) $85 \%$ dos atendimentos podem ser considerados de rotina, isto é, sem risco de vida. Como muitos desses problemas, considerados de rotina, implicam sofrimentos ou preocupações nos pacientes, criam-se situações específicas que não deveriam aguardar uma consulta agendada. É o caso de uma criança com vômito ou febre superior a $38,5^{\circ} \mathrm{C}$ a requerer algum cuidado, ainda que não seja de urgência/ emergência. Nestas e em outras situações similares justificaria o serviço denominado de 'pronto-atendimento'. Neste serviço, podem ser atendidas situações que não 
deveriam aguardar consulta marcada e, até mesmo, atendimento de urgência mais simples como suturas, nebulizaçōes, etc.

\section{Risco de Vida e ContinuUm da Urgência}

O critério fundamental de distinção, apontado por Jairnilson Silva Paim, entre emergência e urgência, e o que não é nem emergente nem urgente, é o risco de vida, avaliado na base do perigo que ameaça a manutenção das funções ditas vitais: ${ }^{4}$ no caso de uma emergência, o risco de vida é 'iminente'; no caso de uma urgência, o risco existe, mas não é 'iminente'; no caso dos problemas ditos 'de rotina', é inexistente.

Na tipologia proposta, a caracterização não se embasa em definições que estabelecem, para cada um dos três tipos de situações ou problemas, caracteres intrínsecos próprios e diferenciadores. Esses não são definidos enquanto estados e, do ponto de vista descritivo, sua caracterização é muito imprecisa e sumária: o autor limita-se a dar exemplos de urgência, de emergência e de casos de rotina. Aliás, o fato de recorrer a exemplos, a própria escolha desses exemplos, testemunha a dificuldade encontrada, fora de contexto, para caracterizar as situações ou casos considerados de 'urgência' e de 'emergência' do ponto de vista de sua nosografia.

Com efeito, no momento do diagnóstico, a avaliação médica necessita da apreensão de um quadro de saúde bem mais complexo, que vai combinando vários sintomas/patologias que não podem ser isolados e considerados um independente do outro. Portanto, dependendo do caso, do quadro geral de saúde e do contexto nos quais se inscreve, uma fratura como também uma asma brônquica podem vir a ser consideradas, sob a perspectiva das definições do próprio autor, năo como 'urgências', mas como 'emergências'.

A urgência e a emergência não são definidas como estados, mas como processos que se originam em pontos diferentes de um mesmo continuum, cujas extremidades opostas são, de um lado, a total ausência de risco de vida - que corresponde aos casos ditos 'de rotina' - e, do outro, a existência de um risco de vida máximo - que corresponde aos casos ditos 'de emergência'. Entre os dois, em um lugar indefinido, intermediário, fica 'a urgência' e os casos assim considerados. A urgência aparece, desse modo, como uma questão de graus ou de níveis.

Acompanhando essa gradação da urgência, três sub-fatores são levados em consideração: tempo, necessidade de agir e gravidade; sendo os três intimamente ligados. Em outros termos, quanto maior é a gravidade, ou seja, maior é a iminência e a importância do 'risco de vida', maior é a necessidade de uma ação terapêutica e menor é o tempo para realizá-la. Mais curto é o tempo, maior é a urgência. Assim, encontramse combinados no continuum, os critérios que o dicionário indica - mas que Paim distingue - nas duas definições.

A caracterização considera duas grandes dimensões do tempo. A primeira diz respeito à velocidade, à rapidez (o fator tempo). A segunda sugere o momento oportuno para agir e pressupõe uma escolha (fator necessidade de agir): na 'emergência' o tratamento tem de ser imediato, já na 'urgência' não há necessidade de agir tão rápido. 
Uma diz respeito à dimensão quantitativa do tempo. A outra remete à dimensão qualitativa, pois a maior ou menor rapidez da ação é o resultado de uma escolha (ligada à apreciação do grau de urgência) que se inscreve em uma ordem de prioridade. Como existe necessariamente um prazo antes da execução, é precisar e decidir o que é tolerável.

Seguindo a lógica do continuum, pode-se considerar que a morte representa por excelência o grau nulo da urgência: de fato, quando ocorre não há mais 'risco de vida' e, por conseqüência, nada mais para fazer. Agora, exceto nesse caso bem claro (e talvez também naqueles que se encontram nas extremidades do continuum), o critério 'risco de vida' é, em si, bastante nebuloso. Apesar de salientar que os estados/situações de saúde que devem ser considerados como de urgência ou de emergência são os que representam uma ameaça para a vida, se nada for feito mais ou menos rapidamente, ele não deixa de ficar indefinido no que diz respeito à sua avaliação e, sobretudo, à avaliação do grau de ameaça que representa para a vida. Como entender e apreender esse critério e seus diversos graus, cuja importância variável justifica, nas definições, a discriminação entre as categorias 'urgências' e 'emergências'?

Entre as duas extremidades do continuum, encontra-se um grande número de casos, mais ou menos 'de emergência', mais ou menos 'urgentes', mais ou menos 'de rotina'. Incorporando a dimensão do tempo, o continuum é dinâmico. E sua dimensão diacrônica - essa da evolução - acaba tornando a caracterização ainda mais imprecisa, abstrata. Senão, vejamos: apesar de não apresentar 'risco de vida iminente', um caso é considerado como sendo 'urgente' justamente por um 'risco de complicações mais graves ou mesmo fatais'. Então, a distinção se torna muito sutil e a urgência pode vir a se tornar uma emergência a qualquer momento. Qual é, então, no caso, o valor operante da distinção entre as duas? Da mesma maneira, um caso de rotina pode vir a tornar-se um caso de urgência, pois, como o próprio Paim indica, alguns deles justificam um 'pronto-atendimento' e até um atendimento dito 'de urgência mais simples'. Mas, então, quais são esses problemas de rotina que, apesar de não urgentes, necessitariam de um atendimento de urgência, mesmo que 'simples'? Será que são problemas que, apesar de serem 'de rotina', não deixam de ser urgentes, mas menos do que outros que, por necessitarem de um atendimento de urgência 'mais complicado', entrariam na categoria das 'urgências'ou das 'emergências'?

\section{Caracterização Imprecisa}

Essa breve análise mostra o quanto a classificação biomédica das urgências a partir de definições ditas 'objetivas' e 'técnicas', nos textos onde se encontram, é pouco satisfatória do ponto de vista da avaliação prática e para o entendimento claro das situações/casos que devem ser considerados como emergentes, urgentes e não urgentes. A tentativa de caracterização, ao invés de de ajudar a estabelecer claramente o conteúdo específico de cada categoria de urgências, aumenta sua imprecisão.

Claro que, no contexto, os médicos dispõem de elementos de conhecimento técnico que lhes permitem apreciar os casos e classificá-los como sendo de 'rotina', de 'urgência', de 'emergência'. Mas isso não resolve a questão do ponto de vista das 
definições biomédicas das noções de 'urgência' e 'emergência', pois esses elementos utilizados nos diagnósticos para a avaliação contextual das situações e problemas de saúde não servem para precisar o conteúdo de noções que as definições biomédicas pretendem, justamente, tornar operante e unívoco (tanto é que essas noções são apresentadas como 'conceitos' em vários textos).

Aliás, parece que uma precisão maior das definições não pode ser encontrada desse lado, já que, como salienta o médico Miguel Martinez Almoyna, do Service d'Aide Médicale Urgente (Samu) de Paris (1997: 1): "analisando a literatura médica, mesmo acadêmica, somos obrigados a constatar que na realidade essa área da medici$\mathrm{na}^{5}$ não possui ainda nosografia precisa". ${ }^{6} \mathrm{O}$ que, segundo ele, constitui um obstáculo para a avaliação. E acrescenta: "infelizmente (...) não há taxinomia precisa que dá as gravidades e as terapêuticas nem os seus derivados temporais". Em numerosos artigos, frutos de suas pesquisas, médicos também mostram a ausência de um índice padrão para a determinação da gravidade dos problemas médicos de urgência e sublinham a dificuldade encontrada para padronizar a interpretação dos critérios de avaliação das urgências médicas (Weinerman et al., 1966; Foldes, Fisher \& Kaminsky, 1994).

Significativas do caráter aproximativo e pouco satisfatório das definições médicas da 'urgência' e da 'emergência' são a multiplicação e a proliferação de suas subdefinições, subdistinções, subdenominações na literatura médica. Encontram-se, ligadas a essas definições, e também às distinções estabelecidas entre elas, as seguintes noções e expressões: 'urgência grave', 'urgência vital', 'urgência extrema', 'situações de alto risco', 'primeira urgência', 'urgências (emergências) verdadeiras', 'urgências reais', 'urgência objetiva', 'urgência absoluta', 'emergência técnica', 'falsas situações de emergência', 'urgências (emergências) falsas', 'urgências presumidas', 'urgência relativa', 'emergência do paciente', 'urgências aparentes', 'urgência subjetiva' etc... A preocupação em conseguir estabelecer um conteúdo mais definido e operante para a urgência acaba se traduzindo pelo aumento da indefinição da noção.

A mesma constatação pode ser feita em textos franceses que também ambicionam atribuir um conteúdo propriamente médico à noção de 'urgência' (urgence). ${ }^{7}$ Uma boa ilustração é a definição proposta pelo Conselho da Europa no seu relatório Etude comparative sur l'organisation et le fonctionnement des services d'aide médicale urgente (1990). Apenas nas duas primeiras páginas de sua introdução, que tem por finalidade definir a urgência, o relatório chega a identificar e a distinguir a 'urgência', a 'urgência subjetiva', a 'urgência objetiva', a 'urgência vital', a 'extrema urgência', a 'primeira urgência', a 'segunda urgência e seguintes'.

Constatando que "a terminologia usada no domínio da ajuda médica de urgência pode variar, não só dentro de um país, mas também entre países de língua idêntica" (1990: 13), o Grupo de Estudo encarregado do relatório procura primeiro definir certos termos, em particular o de urgência, a partir de "questionários e de visitas feitas aos Estados membros" da comunidade européia. Apoiando-se nos dados assim recolhidos, há um esforço "em retomar a terminologia adotada pelo corpo médico e pelas autoridades da saúde pública, com a preocupação também de encontrar definições aceitáveis por todos os Estados membros" (1990: 13). Eis o resultado, tal como apresentado nas páginas introdutórias do relatório (1990: 13-14): 
URGÊNCIA (somente no contexto médico)

DEFINIÇÃo

Necessidade de agir com rapidez, cuidar sem espera. (dicionário Le Petit Robert)

\section{Comentários}

1. Pode-se fazer a distinção entre uma urgência 'subjetiva' e uma urgência 'objetiva', as duas noções podendo se referir a pessoas e seu estado de saúde ou a situações consideradas perigosas pela saúde.

2. Uma urgência ou situação de urgência subjetiva se baseia, sobretudo, na ótica de uma vítima e do público, em critérios impressionantes, tais como dor aguda, hemorragia externa ou desamparo, sem que esses fenômenos coloquem necessariamente em perigo a vida ou a saúde de uma pessoa. Sem as noções de primeiros socorros, o público não sabe apreciar e controlar de maneira correta uma situação nem fazer um diagnóstico sumário antes de chamar com precipitação a ajuda médica urgente.

3. Uma urgência objetiva pode ser apreciada corretamente pelos socorristas, os auxiliares de ajuda médica urgente e os médicos. Todos sâo capacitados para intervir no local e resolver com meios simples a situação de urgência dita subjetiva, por exemplo, com analgésicos, curativos e reconforto. Em uma situação de urgência dita objetiva, eles usam dos meios da ajuda médica urgente, para descartar uma ameaça de morte imediata ou de lesão grave.

4. Faz parte da urgência objetiva: a urgência vital. Ela é definida por várias autoridades de saúde pública como sendo o estado de uma vítima, cujas funções respiratórias, circulatórias ou cerebrais estão paradas ou impedidas, ou arriscam falhar a curto prazo.

5. Classificação das urgências médicas. Os pacientes que precisam de cuidados urgentes são classificados, sobretudo no caso de chegada maciça de feridos, segundo a prioridade do tempo necessário para tomar as medidas terapêuticas. Tal classificação corresponde também à noção de triagem.

a. Extrema urgência - o tratamento é imperativo no espaço de segundos ou minutos para restabelecer as funções vitais respiratórias, circulatórias ou cerebrais. São 'os gestos que salvam a vida'.

b. Primeira urgência - o tratamento é indicado em uma ou algumas horas. Prioridade de transporte no caso de vários feridos.

c. Segunda urgência e seguintes - o tratamento e o transporte são admissíveis em um prazo prolongado. 
Apesar de procurar definir a urgência "somente no contexto médico" (1990: 13), o grupo de estudo toma emprestado a definição da palavra de um dicionário de língua francesa, Le Petit Robert: a urgência é a "necessidade de agir com rapidez, cuidar sem espera".

A referência a um conteúdo mais especificamente médico aparece nos comentários, quando é proposta a distinção entre uma 'urgência subjetiva' e uma 'urgência objetiva', as duas aplicando-se "a pessoas e ao seu estado de saúde ou a situações perigosas para a saúde" (1990: 13).

Ora, é interessante notar que, no momento de definir o conteúdo específico da noção de 'urgência objetiva', o critério invocado pode ser considerado de 'autoridade' na medida em que estabelece que a 'urgência objetiva' é a urgência 'apreciada corretamente' pelos profissionais da saúde, mas não diz nada sobre a 'urgência' enquanto tal. Não serve para esclarecer o que é a urgência tal como ela foi definida no que precede, a saber, como estado ou situação de saúde. Ele só estabelece a competência exclusiva de um tipo de autoridade legítima sobre a atribuição do caráter de urgência a um estado ou uma situação de saúde. Em outros termos, a urgência 'objetiva', isto é, essa que realmente existe, é a que é reconhecida como tal pelos profissionais da saúde. Fora essa, toda urgência é considerada 'subjetiva', subentendido: potencialmente 'inexistente' ou resultando de uma apreciação errada. A 'urgência médica' é definida por seus especialistas legítimos e por oposição à urgência 'subjetiva'.

Uma vez estabelecida a existência de uma urgência objetiva, a tentativa é de precisar melhor seu conteúdo distinguindo e delimitando, dentro dessa categoria geral, vários tipos de urgências. Primeiro há a 'urgência vital', que deve corresponder ao que é caracterizado como 'emergência' nos textos médicos e de saúde pública brasileiros. Depois vem uma classificação das urgências objetivas por ordem de prioridade no atendimento, que desenha uma gradação dos vários tempos para agir conforme os diversos níveis de 'gravidade': há a 'extrema urgência' (não se sabe se corresponde ou não à 'urgência vital'), a 'primeira urgência', a 'segunda urgência', e assim por diante.

Será que essas definições (brasileiras, francesas) contêm informações, elementos explicativos ou descritivos que esclarecem, do ponto de vista técnico e operante, $o$ que é uma urgência médica? No que diz respeito aos estados e situaçōes de saúde, que merecem ser assim considerados, não fornecem elementos de entendimento e discriminação. Só insistem no fato de que devem ser considerados como urgência médica, estados e situações de saúde que representam urgências objetivas, ou seja, que apresentam um risco 'real' para a vida, e que entre elas algumas são mais urgentes do que outras, dependendo justamente do nível de ameaça.

Não definem um conteúdo propriamente médico-técnico para a noção de urgência que a distinga nitidamente da compreensão que o senso comum tem dessa noção, pois qualquer um é levado a considerar como urgência um estado ou uma situação de saúde que lhe parece pôr a vida (sua ou a de outrem) em risco. Essa apreciação, errada ou justa do ponto de vista biomédico, não é propriamente médica, ela é a de todo mundo.

A competência médica se manifesta nos elementos de conhecimento e nas técnicas dos quais dispõe para conferir, confirmar ou infirmar essa apreciação. Aliás, até 
examinar melhor o caso e estabelecer um diagnóstico e um prognóstico mais esclarecidos, os próprios médicos e socorristas partem de uma primeira apreciação clínica que pode vir a ser, ou não, confirmada depois pelo exame clínico mais aprofundado, pelos elementos de diagnóstico fornecidos pelos instrumentos e técnicas dos quais dispõem e pela própria evolução do estado de saúde do paciente. Essa consideração se verifica particularmente no que diz respeito à apreciação do 'grau' de gravidade apresentado pelo caso que leva a considerá-lo como sendo 'urgente', mais ou menos 'urgente' do que um outro, e até não urgente. Assim, apesar de ser guiada por elementos do conhecimento médico técnico, a primeira avaliação biomédica que decide do caráter e do grau de urgência de um estado de saúde também se baseia em elementos 'subjetivos'.

\section{Objetividade Médica Versus Subjetrvidade Leiga}

Este último comentário leva a considerar, com mais atenção, a distinção estabelecida no relatório do Conselho da Europa, entre 'urgência subjetiva' e 'urgência objetiva'. Resultado de uma apreciação correta da urgência, que é a dos especialistas médicos, a urgência objetiva se vê caracterizada por sua oposição com a urgência subjetiva, resultado de uma apreciação errada da urgência que é a do não especialista (doente, vítima, público). É também comum encontrar em textos médicos e de saúde pública brasileiros, que procuram definir a urgência e a emergência, essa oposição entre uma urgência não esclarecida e uma urgência esclarecida. Incorporada à própria definição médica da urgência/emergência, a oposição tende a estabelecer de maneira indiscutível - apesar de não discutida - a existência real da urgência e da emergência quando apreciadas, como tal, pelos profissionais da saúde e a sua inexistência (ou potencial inexistência) quando existente para os não-médicos.

Ao lado da oposição 'urgência objetiva/ urgência subjetiva', encontram-se, nos textos consultados, as duplas de oposições seguintes: 'urgências reais'/'urgências aparentes'; 'urgências (emergências) verdadeiras'/ 'urgências (emergências) falsas'; 'urgências absolutas'/'urgências relativas'; 'emergência técnica'/'emergência do paciente'; 'urgência médica'/'urgência psicológica'. Quaisquer que sejam as denominações e oposições adotadas, a urgência (emergência) 'subjetiva', 'aparente', 'falsa', 'psicológica' é sempre definida como a 'do paciente', da vítima, do público. $\mathrm{O}$ artigo "Implantação de um sistema de triagem em Unidade de Emergência", escrito por Magalhães et al. (1989: 182-183), da Unidade de Emergência do Hospital das Clínicas de Porto Alegre, é mais uma ilustração dessa postura. No parágrafo intitulado "Conceitos e definições de termos", a emergência é definida a partir da oposição entre o que os autores chamam de "conceitos de emergência técnica e de emergência do paciente":

Emergência técnica (é) a situação de saúde do paciente, expressa por sinais e sintomas, que apresenta risco de vida, necessitando de tratamento imediato.

Emergência do paciente (é) a situação de saúde percebida pelo paciente como necessitando de tratamento imediato, mas que, após avaliação técnica, não se configura como tal, podendo receber atendimento ambulatorial a curto ou médio prazo. 
Falar em 'emergência do paciente' testemunha, por um lado, o reconhecimento de uma percepção leiga da urgência/emergência; por outro lado, apresentar essa percepção como sendo por princípio errada ou mal informada acaba negando ao nãoespecialista médico qualquer aptidão para apreciar com justeza a existência de uma emergência. Isso porque, na ignorância dos conhecimentos técnicos necessários, sua avaliação só pode ser embasada em elementos subjetivos, entre os quais os que mais impressionam, os mais 'espetaculares', 'aparentes', os que, afinal, enganam o leigo.

Definir como errada ou potencialmente errada a urgência e a emergência 'do paciente', estabelecendo que a 'subjetividade' é própria do leigo, acaba reforçando por um efeito de definição - o que as próprias definições médicas tentam estabelecer sem demonstração convincente, a saber, que existe uma urgência/emergência cuja existência é determinada somente a partir de elementos objetivos, técnicos. Essa apreciação totalmente objetiva e, por isso, certa, própria e exclusiva do médico, passa a ser o critério que define a 'verdadeira urgência' e acaba estabelecendo não só a justeza da apreciação médica, mas também seu caráter infalivel. O médico não pode se enganar (ser enganado). Afinal, é como se o que distingue mais o que é urgente/emergente do que não é, é a objetividade (o saber) de quem sabe (o médico) contra a subjetividade (a ignorância) de quem não sabe (o leigo).

Definir a urgência/emergência discriminando entre urgência/ emergência 'objetiva' e urgência/emergência 'subjetiva' poderia apresentar, em si, um interessante valor heurístico, na medida em que essa distinção incorpora e assinala, nas próprias definições da urgência/ emergência, a dimensão ao mesmo tempo 'objetiva' e 'subjetiva' da avaliação dos estados de saúde assim apreciados. Mas a definição, ao invés de conciliar as duas dimensões faz uma oposição entre elas a partir de uma separação, excessiva e muito discutível, embasada nas seguintes duplas de oposições e correspondências: objetivo/subjetivo, certo/errado, médico/ leigo.

É como se, diante da dificuldade encontrada para definir a urgência/emergência a partir de elementos exclusivamente técnicos, houvesse uma tentativa para resolver o impasse estabelecendo que a urgência/ emergência 'objetiva', 'técnica', é objetiva, pois ela é do médico, isto é, são os profissionais da saúde que garantem a 'objetividade' de sua avaliação e, por conseqüência, de sua existência. Quando o médico diagnostica uma urgência/emergência é porque ela existe. O contrário também vale: quando o médico não diagnostica uma urgência é porque ela não existe. Nenhum elemento considerado 'subjetivo' - por não ser técnico - entraria na avaliação médica da urgência/emergência e de seus vários graus, já que a 'subjetividade' é o que caracteriza, por definição, a avaliação leiga dos estados de saúde.

Claro que não é tão simples assim e nem tão caricatural como parece. No conjunto das definições biomédicas encontradas, nenhuma se deixa caracterizar como técnica, nenhuma é satisfatória do ponto de vista operante. Há uma considerável imprecisão quanto às variadas situações e aos vários estados de saúde que podem ser conceituados como urgentes e/ou emergentes. Em vez de atribuir um conteúdo unívoco às noções e distinções que procuram precisar, as definições chegam ao exato oposto, pois abrem a possibilidade de interpretações múltiplas. Afinal de contas, o que mostra claramente a análise das definições propostas é o quanto se revela difícil definir de maneira 
exclusivamente técnica a 'urgência', a 'emergência' e o que as distinguem, ou melhor, o quanto essas noções e distinções não se deixam definir de maneira exclusivamente técnica. Daí o impasse objetivista no qual se encontram as tentativas de definições biomédicas da urgência/emergência médicas. Pois os critérios técnicos não dão conta.

A apreciação que leva a considerar um estado ou uma situação de saúde como sendo uma 'urgência' ou uma 'emergência' é o resultado, na prática do médico como na do leigo, de uma combinatória plurifatorial complexa, na qual não entram somente elementos do conhecimento médico técnico. Essa combinatória é a conjunção de uma multiplicidade de fatores de natureza variada, tanto sociais quanto psicológicos, tanto coletivos quanto individuais, tais como, por exemplo: a idade do paciente, seu sexo, sua aparência, condição social, o tipo de mal do qual ele está padecendo, seu comportamento, o tipo de acidente sofrido, o número de vítimas, o grau de angústia e incerteza, a formação do médico, a eventual relação terapêutica existente entre ele e o doente (este é ou não 'seu' paciente) e também o próprio valor atribuído a um estado de saúde por parte de quem decide da sua 'urgência' ou 'emergência', quer dizer, por parte de quem o valoriza como 'urgência'/'emergência'.

Mesmo no interior de uma avaliação propriamente clínica de um estado de saúde, há a participação de uma parte importante de 'subjetividade', particularmente quanto à apreciação de sua evolução. O prognóstico médico, que entra como um dado importante na determinação do grau de urgência do caso, integra muitos elementos de natureza probabilística, e, por essa razão, remete mais a uma aposta esclarecida do que a uma certeza objetiva. E não somente isso. Estudos médicos revelam que a adoção por diversos médicos de um mesmo instrumento objetivo de definição e identificação das emergências desemboca em avaliações variáveis, e até divergentes, dos mesmos casos. Assim, na pesquisa realizada por Foldes, Fisher e Kaminsky (1994), as avaliações de duas médicas encarregadas de analisar retrospectivamente, e de maneira independente, as fichas médicas de 219 pacientes atendidos nos prontos-socorros de dois hospitais urbanos americanos, revelam, entre elas, uma variação enorme na porcentagem dos casos considerados emergências.

Com a preocupação de estabelecer critérios objetivos de exame, as médicas adotaram a mesma lista de sintomas desenvolvida pela American College of Emergency Physicians (Acep) para definir as emergências. Mesmo se referindo aos mesmos critérios, e apesar de suas impressões clínicas serem quase similares, uma considera que $90 \%$ dos 219 casos representam emergências certas e prováveis, enquanto a outra, somente $36 \%$. Os autores do artigo observam que "esses critérios objetivos" [de avaliação] se desintegram diante da visão que cada médica tem do que constitui uma "emergência" (1994: 837) e mostram que as divergências entre suas apreciações estão, por muito, ligadas a abordagens diferentes da prática da medicina decorrentes da sua especialidade e treinamento (uma é especialista em medicina de urgência enquanto a outra é um general internist, especialista em doenças orgânicas). E concluem escrevendo: "pode ser que o consenso profissional sobre o que chamar uma 'emergência' e onde tratá-la seja mais uma questão de formação, especialidade e crenças do médico do que de certeza cientifica" (1994: 840). 
No domínio da biomedicina, a 'urgência' e a 'emergência' não são noções, e ainda menos conceitos, técnicos ou teóricos médicos. Não existem 'a urgência' e 'a emergência', mas as 'urgências' e as 'emergências' na apreciação das quais entra uma constelação de elementos que não são só de natureza biológica, fisiológica, mas que pertencem a várias ordens de realidade. A valorização de um estado de saúde como urgência ou emergência ao mesmo tempo traduz o reconhecimento da sua gravidade e justifica a prioridade dada no atendimento. $\mathrm{O}$ que forja essa apreciação, o que leva a esse diagnóstico, quer seja leigo ou biomédico, não escapa do social e de suas várias expressões e determinações.

É o que mostra a abordagem antropológica da urgência/emergência, quando, em uma ótica crítica e distanciada, procura entender o que é urgência e emergência a partir dos dados recolhidos no campo, isto é, partindo dos discursos e da observação das práticas efetivas dos vários atores implicados nas situações.

\section{NOTAS}

1 Importa assinalar, sem aprofundar, pois essa discussão foge do nosso assunto, que a denominação genérica 'povo' usada pelos médicos para designar o conjunto dos pacientes é significativa da grande distância social por eles vivida e estabelecida com os usuários. De fato, os pacientes que eles atendem nos prontos-socorros pertencem, na sua grande maioria, às camadas sociais inferiores. São eles que constituem o 'povo', no qual os médicos (assim como muitos outros brasileiros que, como eles, pertencem a camadas sociais bem mais favorecidas) não se incluem.

2 Ver Aranha (1969: 26).

3 Ver Aranha (1969: 26).

4 As funções vitais, às quais se refere o autor, sem citá-las, são definidas em outros textos como sendo as funções respiratórias, circulatórias e cerebrais.

5 Isto é, a medicina de urgência.

6 Neste livro, as citações de referências bibliográficas cujo original encontra-se em inglês ou em francês, como neste caso, foram traduzidas livremente.

7 No domínio da biomedicina, recorre-se em francês a apenas uma palavra urgence (diversamente qualificada) para denominar o que, em português, é designado por 'urgência' ou 'emergência'. 


\section{2 \\ Método, Locais e Caminhos da Pesquisa}

\section{MARíLIA}

No oeste do Estado de São Paulo, na região denominada Alta Paulista, localizase a cidade de Marília, onde foi realizada a pesquisa que deu origem a este livro. Nascido da incorporação de três povoados ${ }^{1}$ que se desenvolveram com o café, ao longo de uma primeira picada aberta em 1913, o município de Marília ocupa hoje uma área territorial de $1.170 \mathrm{~km}^{2} \mathrm{e}$ conta com uma população de 197.342 moradores, em grande parte urbana e alfabetizada, e em crescimento. ${ }^{2}$

A economia do município está centrada nos ramos da agricultura, pecuária, silvicultura, sericicultura e indústria de transformação. A produção agropecuária é bastante diversificada, com predominância do café, milho, pecuária de leite e corte. No que diz respeito às indústrias, prevalecem as de pequeno porte, com destaque para as indústrias de metalurgia. $\mathrm{O}$ município também concentra um grande número de indústrias alimentícias, particularmente voltadas à produção de balas, doces e biscoitos. Elas dão a Marília seu cheiro característico de bolo assando e conferem-lhe o título de Capital Nacional do Alimento. Mas é o setor terciário o maior responsável pela ocupação da população economicamente ativa.

Marília também é um pólo universitário importante do interior paulista. Ela possui duas universidades: uma pública, que é uma unidade da Universidade Estadual Paulista (Unesp), voltada para as áreas de filosofia e ciências; e uma privada, a Universidade de Marília (Unimar). Tem ainda duas fundações: uma privada, a Fundação de Ensino Eurípides Soares da Rocha, que ministra cursos de administração, ciências contábeis e direito; uma pública, a Fundação Municipal de Ensino Superior, responsável pela Faculdade de Medicina de Marilia (Famema), que funciona em conjunto com o Hospital das Clínicas - hospital universitário - onde o campo etnográfico elegeu um de seus locais de investigação privilegiados, isto é, o pronto-socorro.

Com relação ao nível de renda da população na área de abrangência do município, em 2000, 42,06\% das pessoas responsáveis pelos domicílios tinham uma renda situada entre menos de meio a três salários mínimos. Concluindo-se que uma parte significativa da população é dependente e usuária dos serviços de acesso gratuito do Sistema Único de Saúde (SUS). 


\section{A Área da SaÚde}

\section{Os Serviços de Saúde}

Marilia faz parte da área de abrangência da DIR-XIV. É servida por uma rede de serviços de saúde, alguns sob a gerência do município ou do estado, outros sob a gerência de entidades filantrópicas e de serviços privados. Na época da coleta dos dados, em $1998,{ }^{3}$ eles eram os seguintes e assim distribuídos:

Quadro 1 - Distribuição dos serviços de saúde em função da gerência

\begin{tabular}{|c|c|c|c|}
\hline $\begin{array}{l}\text { SOB A Gerfácl } \\
\text { Do Município }\end{array}$ & $\begin{array}{l}\text { Sob a GeRẼNCla } \\
\text { DO Estado }\end{array}$ & $\begin{array}{l}\text { Sob a GERANCIA } \\
\text { DE ĖNTDADES } \\
\text { FHLANTRÓPICAS }\end{array}$ & $\begin{array}{l}\text { Sob a Gerícia dE } \\
\text { Serviços Privados }\end{array}$ \\
\hline $\begin{array}{l}26 \text { Unidades Básicas de } \\
\text { Saúde (UBS) }\end{array}$ & $\begin{array}{l}2 \text { hospitais universitários: } \\
\text { Hospital das Clinicas } \\
\text { e Hospital Municipal } \\
\text { (referência rcgional de } \\
\text { atendimento terciário) }\end{array}$ & $\begin{array}{l}\text { Santa Casa de } \\
\text { Misericórdia }\end{array}$ & $\begin{array}{l}23 \text { serviços } \\
\text { ambulatoriais }\end{array}$ \\
\hline 1 centro de saúde & $\begin{array}{c}1 \text { faculdade de medicina: } \\
\text { Famema }\end{array}$ & $\begin{array}{l}\text { Hospital Espirita } \\
\text { (psiquiátrico) }\end{array}$ & $\begin{array}{l}328 \text { consultórios e } \\
\text { clinicas médicas }\end{array}$ \\
\hline $\begin{array}{l}59 \text { consultórios } \\
\text { odontológicos }\end{array}$ & $\begin{array}{c}1 \text { curso enfermagem } \\
1 \text { curso de fonoaudiologia } \\
\text { (Uncsp) }\end{array}$ & $\begin{array}{c}\text { Hospital São Francisco } \\
\text { de Assis }\end{array}$ & $\begin{array}{c}1 \text { faculdade de medicina } \\
\text { (Unimar) }\end{array}$ \\
\hline - & $\begin{array}{l}\text { Núcleo de Gestão } \\
\text { Assistencial }\end{array}$ & $\begin{array}{l}\text { Hospital Maternidade } \\
\text { Gota de Leite }\end{array}$ & - \\
\hline - & Laboratório Adolfo Luz & - & - \\
\hline- & Hemocentro & - & - \\
\hline
\end{tabular}

Fonte: Plano de Saúde do município de Marilia (1997). 


\section{Os Prontos-Socorros}

Com relação ao atendimento de urgência e de emergência nos hospitais, a cidade possui quatro prontos-socorros cuja capacidade operacional e de resolubilidade varia segundo os lugares. Eles são assim classificados:

Quadro 2 - Caracterização do atendimento segundo os prontos-socorros

\begin{tabular}{|c|c|}
\hline Hospital. & Características do Pronto-Socorro \\
\hline Hospital das Clinicas & $\begin{array}{l}\text { Atendimento de urgências/cmergências clínicas e cirúrgicas com } \\
\text { traumato-ortopedia e Unidade de Terapia Intensiva. }\end{array}$ \\
\hline Santa Casa de Miscricórdia & $\begin{array}{l}\text { Atendimento de urgências } / \text { emergências clínicas c cirúrgicas } \\
\text { com traumato-ortopedia e Unidade de Terapia Intensiva. }\end{array}$ \\
\hline São Francisco de Assis & $\begin{array}{l}\text { Atcndimento de urgências/cmergências clínicas c cirúrgicas } \\
\text { com traumato-ortopedia }\end{array}$ \\
\hline $\begin{array}{l}\text { Maternidade } \\
\text { Gota de Leite }\end{array}$ & Atendimento de urgências/cmergências clínicas c cirúrgicas \\
\hline
\end{tabular}

Fonte: Projeto de urgência e emergência da DIR-XIV - Marília - 1998.

O pronto-socorro do Hospital das Clínicas (com funcionamento 24h por dia) é responsável pelo maior número de atendimentos. Em novembro de 1997, bem no início do trabalho de campo, o pronto-socorro do Hospital Municipal - onde eram prestados os atendimentos nas áreas de clínica médica, cirurgia geral e especializada, psiquiatria, ortopedia e oftalmologia - foi transferido para o pronto-socorro do Hospital das Clínicas, que, atuando até então somente nas áreas de pediatria (clínica e cirúrgica), ginecologia e obstetrícia, passou a atender em todas as áreas. A tabela seguinte testemunha o número importante de atendimentos por ele realizado:

Tabela I - Quantidade de atendimentos prestados pelo pronto-socorro do Hospital das Clínicas nos seis primeiros meses de 1998

\begin{tabular}{l|c|c|c|c|c|c|c}
\hline \multicolumn{1}{c|}{ PS do HC } & Jan. & Fcv. & Mar. & Abr. & Maio. & Jun. & Tors. \\
\hline Quantidade atendida & 10.533 & 11.578 & 14.315 & 15.316 & 15.983 & 16.475 & 84.200 \\
\hline Quantidade atendida por sexo: & & & & & & & \\
- Homens & 5.364 & 5.945 & 7.276 & 7.813 & 8.116 & 8.106 & 42.620 \\
- Mulheres & 5.169 & 5.633 & 7.039 & 7.503 & 7.867 & 8.369 & 41.580 \\
\hline Quantidade atendida por DIR: & & & & & & & \\
- Marília & 9.148 & 10.146 & 12.557 & 13.341 & 14.074 & 14.645 & 73.911 \\
- Outros DIR & 1.062 & 1.127 & 1.416 & 1.622 & 1.636 & 1.551 & 8.414 \\
- Não informados c não classificados & 323 & 305 & 342 & 353 & 273 & 279 & 1.875 \\
\hline
\end{tabular}

Fonte: Setor de Estatística Médica do Hospital das Clínicas de Marília. 


\section{As Centrais de Cilamadas}

Pertencem também à rede pública de atendimento às urgências e emergências da cidade duas centrais de chamadas com sistema de atendimento móvel e funcionamento $24 \mathrm{~h}$ por dia: o 193 e o 192 . Os veículos e profissionais dessa ajuda móvel atendem as pessoas nos locais onde se encontram (casa, rua etc.), dão-lhes uma assistência médica de primeiro-socorro, e as conduzem para os prontos-socorros da cidade, geraimente o do Hospital das Clínicas.

O 193 é a Central do Corpo de Bombeiros que recebe solicitações de intervenções por meio deste número de telefone gratuito tanto para situações especificas de bombeiro, como incêndio, por exemplo, quanto para atendimentos de urgência de todas as modalidades. A recepção das chamadas e sua triagem são realizadas por bombeiros do Comando de bombeiros (Cobom). Um bombeiro atende as chamadas de dia e um outro à noite.

Eis a seguir, exemplos representativos dos tipos de ocorrências atendidas pelo 193 , tais como foram registradas em referência à classificação das ocorrências no Cobom, nas fichas pelos bombeiros preenchidas:

Quadro 3-Ocorrências atendidas pelo Resgate - 1998, de 00h a 24h

\begin{tabular}{|c|c|c|}
\hline $19 / 02$ & $20 / 04$ & $01 / 05$ \\
\hline Vazamento GLP/fogo & Queda & 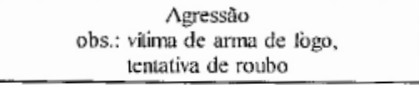 \\
\hline $\begin{array}{l}\text { Acidenie de trârsito com vitima } \\
\text { obs.: suspeita fratura omoplata }\end{array}$ & $\begin{array}{l}\text { Caso clínico } \\
\text { obs.: cntorse na coluna }\end{array}$ & $\begin{array}{l}\text { Acidente de trânsilo com vitima } \\
\text { obs.: vitima com ferimentos graves na cabeça, } \\
\text { carro } x \text { moto }\end{array}$ \\
\hline $\begin{array}{c}\text { Queda } \\
\text { obs.: escoriaçð̄es canela * }\end{array}$ & $\begin{array}{l}\text { Caso clinico } \\
\text { obs.: parada cardiaca, } \\
\text { atestada pelo Dr. } \mathrm{X}\end{array}$ & $\begin{array}{l}\text { Animal em local de risco } \\
\text { obs.: coeho tubulaçoes }\end{array}$ \\
\hline Queda & $\begin{array}{l}\text { Acidente de trânsito com vitima } \\
\text { obs.: fratura de tbia e fibula }\end{array}$ & $\begin{array}{c}\text { Atropelamento } \\
\text { obs.; vitima com escoriaçōes braços }\end{array}$ \\
\hline Caso clinico & Parturiente & $\begin{array}{l}\text { Queda } \\
\text { obs.: vitima suspeila fratura cokma }\end{array}$ \\
\hline $\begin{array}{l}\text { Transporte emergencial? } \\
\text { obs.: transporte até sua } \\
\text { residência - Sitio Sto. Antônio } \\
\text { Nova Columbia }\end{array}$ & $\begin{array}{c}\text { Queda } \\
\text { obs:: trauma na face }\end{array}$ & $\begin{array}{l}\text { Caso clinico } \\
\text { obs.: crise convulsiva }\end{array}$ \\
\hline Caso clinico & $\begin{array}{c}\text { Incêndio } \\
\text { obs.: fogo } \mathrm{cm} \text { terreno baldio }\end{array}$ & Queda \\
\hline Queda & Animal perigoso & Animal agressivo \\
\hline Acidente de trânsito com vítima & $\begin{array}{c}\text { Caso clínico } \\
\text { obs.: crise convulsiva }\end{array}$ & $\begin{array}{c}\text { Atropelamento } \\
\text { obs.: escoriaçōes no rosto }\end{array}$ \\
\hline Atropelamento & $\begin{array}{l}\text { Caso clinico } \\
\text { obs.: febre }\end{array}$ & $\begin{array}{c}\text { Queda } \\
\text { obs : corte e contusăa na cabeça }\end{array}$ \\
\hline Caso clínico & $\begin{array}{c}\text { Caso clinico } \\
\text { obs.: insuficiência respiratóra }\end{array}$ & Exterminio inseto agressivo \\
\hline Atropelamento & Paruriente & - \\
\hline Pessoa em local de risco & Exterminio maribondo & - \\
\hline- & $\begin{array}{c}\text { Caso clínico } \\
\text { obs.: insuliciência respiratória }\end{array}$ & - \\
\hline - & Caso clinico & - \\
\hline
\end{tabular}

Fonte: Fichas de ocorrências do Serviço de Resgate de Marília. 
O serviço de resgate do Corpo de Bombeiros do $10^{\circ}$ Grupo de Intervenção (GI) de Marília tem a missão específica de prestar assistência às vítimas em situação de emergência. Ele conta com três viaturas para o atendimento das vítimas, denominadas Unidades de Resgate (UR-17, UR-163, UR-164), e com setenta bombeiros que receberam um treinamento em suporte básico de vida de $40 \mathrm{~h}$. As URs ficam sediadas nos quartéis do Corpo de Bombeiros, distribuídos estrategicamente em dois postos da cidade, para prestar um atendimento mais rápido, e operam geralmente com dois ou três bombeiros. No período noturno, durante os finais de semana e os feriados, alunos do quarto e quinto ano de medicina da Famema, que participam do projeto Alfa, ${ }^{8}$ integram a equipe de resgate e acompanham os bombeiros na suas saídas, um aluno por viatura.

Segundo dados do Anuário Estatístico do Corpo de Bombeiros, o Resgate de Marília atendeu, em 1997, 2.724 ocorrências, com um total de 2.649 vítimas, sendo dessas, 2.555 salvas. As ocorrências mais numerosas dizem respeito ao que os bombeiros classificam como "caso clínico", "acidente de trânsito com vítima", "queda", "atropelamento", "acidente pessoal".

Marilia conta ainda com o 192, um sistema de atendimento móvel municipal, a Central de Ambulâncias, oficialmente destinada a atender às urgências/emergências médicas, por meio de suas ambulâncias e deste número de telefone gratuito. As chamadas que caem no 192 são recebidas e triadas por uma escriturária e um mensageiro durante o dia, e por motoristas à noite.

A Central trabalha com três ambulâncias, ${ }^{9}$ dirigidas por motoristas que receberam treinamento de suporte básico de vida. As ambulâncias saem geralmente com um motorista; às vezes com dois, quando vão buscar uma pessoa cujo estado é avaliado, a partir dos elementos recolhidos no telefone, como necessitando da atuação de mais pessoas. Durante as sete noites da semana, alunos de enfermagem da Famema que participam do projeto Alfa dão plantões na Central e acompanham os motoristas em suas saídas noturnas, um aluno por viatura.

Dezoito pessoas trabalham para o 192: quinze motoristas, um mensageiro, uma escriturária e o responsável pela Central. Os motoristas trabalham a cada dois dias, três ficando no plantão de dia e três no plantão à noite. O sistema 192 atende um grande número de pedidos, como mostra a tabela seguinte:

Tabela 2 - Número de atendimentos mensais prestados pela Central de Ambulâncias em 1996, 1997 e nos oito primeiros meses de 1998

\begin{tabular}{c|c|c|c|c|c|c|c|c|c|c|c|c|c}
\hline Ano & Jan. & Fev. & Mar. & Abr. & Maio. & Jun. & JuL & Ago. & Set. & Out. & Nov. & Dez & TorN. \\
\hline 1996 & 1794 & 1827 & 1941 & 1939 & 1774 & 1718 & 2253 & 3224 & 2904 & 3002 & 1963 & 1713 & 26052 \\
\hline 1997 & 1643 & 1730 & 1771 & 1534 & 1692 & 1786 & 1668 & 1827 & 1797 & 1802 & 1609 & 1559 & 20418 \\
\hline 1998 & 1438 & 1218 & 1308 & 1375 & 1314 & 1371 & 1215 & 1301 & - & - & - & - & - \\
\hline
\end{tabular}

Fonte: Relatórios semanais, mensais e anuais da Central de Ambulâncias.

Também muito significativos da intensa atividade da Central são os quilômetros percorridos pelas ambulâncias e a quantidade de combustível por elas consumida para 
atender a população de Marília e distritos. Em 1996, elas rodaram $236.389 \mathrm{~km}$, e, em 1997 , 214.330. Mais detalhadamente, por exemplo, no mês de dezembro de 1996, em que prestaram 1.713 atendimentos, percorreram um total de $19.434 \mathrm{~km}$ e consumiram 4.084 litros de combustível. Um ano depois, em dezembro de 1997, passaram para 1.559 atendimentos prestados, elas rodaram $13.419 \mathrm{~km}$ e consumiram 4.152 litros de combustível. ${ }^{10}$

Entre as chamadas recebidas pela Central a propósito de um problema de saúde, a maioria diz respeito a casos classificados, pelos atendentes e motoristas, como 'psiquiátricos', 'clínicos' e 'obstétricos', e resultam no transporte dos pacientes para um pronto-socorro, geralmente o pronto-socorro do Hospital das Clínicas. As ambulâncias servem também como transporte social para altas hospitalares, retornos e exames médicos como bem mostra a tabela seguinte, representativa da natureza da demanda e dos serviços prestados pelo 192 :

Tabela 3 - Motivos de saída das ambulâncias segundo classificação da Central para os meses de fevereiro - 1996, 1997, 1998

\begin{tabular}{|c|c|c|c|}
\hline Motivos de SAIDA dAs AmbULÂANCIAS & fev. de 1996 & fev. de 1997 & fev. de 1998 \\
\hline Pacientes de urgência para PS & $\begin{array}{c}1.069 \\
(58,51 \%) \\
\end{array}$ & $\begin{array}{c}1.037 \\
(59,94 \%) \\
\end{array}$ & $\begin{array}{c}725 \\
(59,5 \%) \\
\end{array}$ \\
\hline Transferência inter-hospitalar & $\begin{array}{c}390 \\
(21,35 \%)\end{array}$ & $\begin{array}{c}294 \\
(17 \%)\end{array}$ & $\begin{array}{c}159 \\
(13,05 \%)\end{array}$ \\
\hline Altas hospitalares levar para casa & $\begin{array}{c}249 \\
(13,63 \%) \\
\end{array}$ & $\begin{array}{c}292 \\
(16,88 \%) \\
\end{array}$ & $\begin{array}{c}232 \\
(19,05 \%) \\
\end{array}$ \\
\hline Saidas para distritos e outras cidades & $\begin{array}{c}86 \\
(4,70 \%) \\
\end{array}$ & $\begin{array}{c}64 \\
(3,70 \%)\end{array}$ & $\begin{array}{c}72 \\
(5,9 \%) \\
\end{array}$ \\
\hline Exames e retomos & $\begin{array}{c}33 \\
(1,81 \%) \\
\end{array}$ & $\begin{array}{c}43 \\
(2,48 \%) \\
\end{array}$ & $\begin{array}{c}30 \\
(2,5 \%) \\
\end{array}$ \\
\hline TOTAL & $\begin{array}{c}1.827 \\
(100 \%) \\
\end{array}$ & $\begin{array}{c}1.730 \\
(100 \%)\end{array}$ & $\begin{array}{c}1.218 \\
(100 \%)\end{array}$ \\
\hline
\end{tabular}

Fonte: Relatórios semanais, mensais e anuais da Central de Ambulâncias.

As saídas de ambulâncias são geralmente tão numerosas durante o dia quanto à noite. Porém, importa ressaltar que as chamadas de ajuda de urgência que resultam no transporte de pacientes para o pronto-socorro são mais numerosas durante o dia, enquanto as relativas a altas hospitalares são mais numerosas no período noturno. Isto se explica porque, à noite, as ambulâncias acabam preenchendo o vazio deixado pela ausência de meio de transporte público. Apesar de essa atividade não fazer parte de suas funções declaradas, as ambulâncias se tornam uma condução gratuita para os pacientes (e seus acompanhantes) que, tendo recebido alta hospitalar, não têm como voltar para casa. A tabela seguinte patenteia a modificação significativa do perfil da demanda e do atendimento entre o dia e a noite. 
Tabela 4 - Motivos de saída das ambulâncias nos períodos diurnos e noturnos do mês de fevereiro de 1998

\begin{tabular}{c|c|c|c|c|c}
\hline MotTVOS DE SAidA DAS AMBULÁNCIAS & Diurno & $\%$ & Noturno & $\%$ & TotAL \\
\hline Pacientes de urgência para PS & 411 & 68,16 & 314 & 51,06 & $\begin{array}{c}725 \\
(59,5 \%)\end{array}$ \\
\hline Transfcrência inter-hospitalar & 80 & 13,27 & 79 & 12,85 & $\begin{array}{c}159 \\
(13,05 \%)\end{array}$ \\
\hline Altas hospitalares levar p/casa & 55 & 9,12 & 177 & 28,78 & $\begin{array}{c}232 \\
(19,05 \%)\end{array}$ \\
\hline Saídas para distritos e outras cidades & 31 & 5,14 & 41 & 6,66 & $\begin{array}{c}72 \\
(5,9 \%)\end{array}$ \\
\hline Exames e retornos & 26 & 4,31 & 04 & 0,65 & $\begin{array}{c}30 \\
(2,5 \%)\end{array}$ \\
\hline ToTAL & 603 & 100 & 615 & 100 & $\begin{array}{c}1.218 \\
(100 \%)\end{array}$ \\
\hline
\end{tabular}

Fonte: Relatórios semanais, mensais e anuais da Central de Ambulâncias.

Entre as duas centrais de chamadas - o 193 e o 192 - é a segunda que, por razões que serão apontadas a seguir, veio a se tornar o segundo lugar de investigação privilegiado da pesquisa de campo, junto ao pronto-socorro do Hospital das Clínicas.

\section{Trabalho de Camp0}

Para atingir as representações e práticas ligadas à urgência e à emergência em saúde, a escolha foi de um método qualitativo. Os dados de observação e de discurso nos quais se embasam as interpretações e análises aqui apresentadas foram recolhidos graças a um trabalho de campo, de tipo etnográfico, realizado entre novembro de 1997 e janeiro de 1999. Num primeiro momento, ele se desenvolveu sucessivamente em três locais da rede pública de atendimento às urgências e emergências de Marília: o prontosocorro do Hospital das Clínicas, a Central de chamadas dos Bombeiros (o 193) e a Central de Ambulâncias da prefeitura (o 192). Na medida em que neles confluem e manifestam-se, por excelência, demandas e atendimentos de urgência, esses lugares representam espaços privilegiados de acesso a observações e discursos de primeira importância para a pesquisa, relativos tanto à percepção e às práticas da urgência e da emergência quanto às interações entre os diversos atores implicados e a suas reações.

Uma vez investigados esses lugares, o trabalho de campo se prolongou fora deles, acompanhando os motoristas da Central de Ambulâncias em suas saídas para a rua. No domínio da urgência/emergência, a expressão da demanda e a realização da conseqüente resposta em termos de atendimento (ou não atendimento), originam um processo cujo desenrolar se dá no tempo e no espaço e que se inicia muitas vezes fora 
do pronto-socorro, por exemplo, a partir de uma ligação para as centrais de chamadas." Apreender a rede de atendimento às urgências/emergências, não só a partir dos seus lugares fixos, mas a partir do movimento e da dinâmica que a animam, é fundamental para entender o processo na sua totalidade e para presenciar como nele se combinam práticas e representações diversas da urgência/emergência, umas compatíveis, outras conflituosas. Acompanhar os motoristas em suas saidas significa, também, ir com eles às casas das pessoas e, assim, ter acesso a elementos inestimáveis de conhecimento dos contextos nos quais se inscrevem as chamadas de urgência.

\section{Observaçáo Participante nos Locais de Atendimento}

Participei do cotidiano nos locais investigados, sobretudo durante o dia, e assim fui recolhendo aos poucos, durante meses, os dados da pesquisa. Devido às peculiaridades dos lugares, o trabalho de campo não se deu da mesma maneira em cada um deles. Ele foi se adaptando aos funcionamentos e ritmos das diversas realidades investigadas, suas atividades e pessoas, hierarquias e resistências. Como qualquer campo etnográfico, este foi se desenvolvendo com a construção progressiva das relações, segundo um movimento que emprestou suas vias e modalidades aos universos estudados.

No pronto-socorro, ${ }^{12}$ o lugar privilegiado da observação e da participação foi a parte aberta ao público, e nela vários espaços cujo trabalho de campo revelou as funç̃es diferentes e as peculiaridades:

- a porta de entrada do pronto-socorro: um segurança fica ali, na parte de fora, $24 \mathrm{~h}$ por dia, e interroga as pessoas que querem entrar sobre o motivo de sua visita;

- a porta que separa a sala de espera adulto da área de atendimento médico adulto, interditada ao público: trata-se de um lugar altamente estratégico, pois é aí que os pacientes (e/ou seus acompanhantes) tentam obter do porteiro - que fica sempre em pé do lado da porta vigiando as entradas - um atendimento mais rápido; é aí também que os acompanhantes tentam conseguir informações sobre o que está acontecendo com o paciente quando ele já está dentro da área de atendimento. Enfim, é deste lugar cobiçado, que procuram vislumbrar o paciente, aproveitando-se das aberturas da porta;

- a recepção: onde os pacientes (e/ou seus acompanhantes) vão preencher sua ficha quando chegam ao pronto-socorro;

- os espaços reservados à espera propriamente dita: salas de espera infantil e adulto, onde encontra-se um conjunto de cadeiras de plástico;

- a parte de fora do pronto-socorro: espécie de excrescência da sala de espera adulto, em contato e comunicação imediatos com ela pela porta de entrada. É um espaço ao ar livre aonde chegam, por uma rampa de acesso, tanto as pessoas que vem a pé ou de carro particular, quanto as viaturas do Resgate e as ambulâncias da prefeitura. Aí 
também ficam esperando pacientes e acompanhantes, mais ou menos numerosos, segundo a importância da afluência.

No pronto-socorro, as partes físicas de atendimento médico adulto e infantil também foram lugares de investigação. Entretanto, importa sublinhar, que apesar de ter sido formalmente aceita nestes lugares desde o início da pesquisa, ${ }^{13}$ o trabalho de campo foi aí dificultado pela resistência perceptível dos profissionais da saúde, geralmente atentos a seus discursos e atitudes em minha presença. Vários comportamen$\operatorname{tos}^{14}$ traduziram seu incômodo (aliás, recíproco) e sua autovigilância. ${ }^{15}$ Recolhi e interpretei os dados, conseguidos nesses lugares, consciente dessa alteração que, aliás, diminuiu bastante com o tempo. ${ }^{16}$

Ao contrário do que aconteceu nas áreas de atendimento médico, a integração na parte aberta ao público foi fácil. Consegui transformar minha presença, de início excepcional e estranha, em uma presença familiar e comum. Não encontrei dificuldade em entrar em contato com os usuários, em desenvolver com eles uma sociabilidade de relações ordinárias. Nas salas de espera, onde eram geralmente numerosos, era percebida como paciente ou acompanhante de doente. Sendo a espera geralmente demorada, muitas são as pessoas que procuram uma conversa para passar o tempo e que abordam, assim, de maneira espontânea, assuntos interessando diretamente a pesquisa: contam os motivos de sua presença, falam do problema que as levou para o pronto-socorro, relatam suas circunstâncias, história e conseqüências, mencionam as pessoas e os acontecimentos envolvidos etc. Expressam sua inquietação, suas queixas, seu aborrecimento... A parte de fora, por ser um espaço onde muitas pessoas saem para conversar e fumar um cigarro, também favoreceu bastante os contatos e as conversas.

Nesses espaços públicos do pronto-socorro, a integração foi facilitada pelo simples fato de que só precisava participar da espera, ficar disponível e mostrar interesse para qualquer conversa para conseguir um papel local. Aproveitando-me dessa situação, não revelei os motivos da minha presença às pessoas que não os questionaram, o que foi o caso da maioria delas.

Com os seguranças, os porteiros e as recepcionistas, a situação foi diferente, pois, ao contrário dos usuários, esses profissionais do pronto-socorro me viam todo dia. Para eles, expliquei que era uma pesquisadora francesa, antropóloga, interessada em conhecer o funcionamento de um pronto-socorro brasileiro, em saber quem o procurava e para que tipo de problemas, e como eram realizados os atendimentos. Exceção feita a um porteiro que manifestou antipatia durante as primeiras semanas, não encontrei resistência por parte desse pessoal, que se mostrou bastante prestativo e cooperador. Foi o caso, especialmente, dos seguranças, que, no intuito de auxiliar-me na pesquisa, tomavam a iniciativa de chamar minha atenção sobre coisas que podia estar ignorando, de informar-me sobre acontecimentos ocorridos em minha ausência e de compartilhar comigo o entendimento que tinham das situações que presenciávamos juntos ou não. A partir de nossas numerosas e longas conversas, ${ }^{17}$ construímos relações descontraídas e de confiança. A mesma coisa aconteceu com as recepcionistas com as quais passei muito tempo. 
Os dados conseguidos no pronto-socorro foram essencialmente recolhidos a partir da observação, da escuta de conversas e comentários e da participação de conversas informais e situações variadas. As poucas entrevistas realizadas foram com médicos e enfermeiras. Com os usuários e os profissionais não médicos do prontosocorro, não recorri à técnica das entrevistas, mesmo que não diretivas. ${ }^{18} \mathrm{Com}$ o objetivo de intervir, o mínimo possivel, em seus discursos e comportamentos, preferi me deixar guiar pelos assuntos espontaneamente abordados nas conversas informais, tentando orientá-los para questões que interessavam mais diretamente a pesquisa, quando era propício e oportuno. Da mesma maneira, não usei gravadores, ainda menos máquina fotográfica e filmadora, cujo uso dentro do pronto-socorro era proibido. ${ }^{19}$

Depois de cinco meses, o trabalho de campo se deslocou para as centrais de chamadas. Nelas, o objetivo principal era recolher o conteúdo das conversas telefônicas. ${ }^{20}$ Por isso, precisava escutar as falas não só dos atendentes, mas também dos solicitante, e, se possível, gravá-las para poder conservar os enunciados exatos e seu encadeamento nas conversas.

No 192, o chefe da Central instalou para mim um telefone que permitiu a escuta dos solicitantes nas suas conversas com os atendentes. Mas, devido a limitações técnicas, a gravação das falas foi muito rudimentar e obtida graças a um pequeno gravador que eu encostava no telefone o tempo que durava a ligação, o que não só dificultou as gravações, mas também impossibilitou gravar as chamadas recebidas durante minha ausência. No 193, não foi possível montar um sistema que me permitisse escutar a fala do solicitante no momento da ligação. Entretanto, um bombeiro instalou um sistema que possibilitou gravar todas as chamadas recebidas de dia e à noite, eu estando ou não presente.

O trabalho de campo nas centrais também permitiu entender o funcionamento e as atividades desses lugares, conhecer seus vários atores, observar as modalidades do desencadeamento (ou não) das respostas técnicas suscitadas pelas chamadas e escutar as conversas por rádio entre atendentes e motoristas. Favoreceu, igualmente, o estabelecimento progressivo de relações de confiança com os motoristas, relações muito importantes para a continuação do trabalho de campo, visto que minha intenção depois era acompanhá-los nas suas saídas.

\section{Observação Participante vas Equipes Móveis}

Uma vez os lugares físicos e fixos da urgência/emergência investigados, o trabalho de campo saiu de seus muros para entrar no movimento das equipes móveis que prestam socorro às pessoas no lugar onde se encontram (casa, rua, lugares públicos, de trabalho etc.). A participação na dinâmica da ajuda móvel de urgência não só permitiu apreender o desenvolvimento inteiro do processo, ${ }^{21}$ mas também comparar o conteúdo verbal e emocional das chamadas ${ }^{22}$ com a realidade das situações e dos estados dos doentes (vítimas). Comparação interessantíssima, na medida em que revelou, na maioria dos casos, diferenças importantes e significativas entre o que é descrito pelos solicitantes no telefone e o que os motoristas encontram no lugar. 
Saí de viatura de maio a setembro de 1998, e ainda em janeiro de 1999, principalmente com os motoristas de ambulâncias do 192 , e muito pouco com os bombeiros do 193. Essa situação foi devida à falta de tempo para acompanhar igualmente uns e outros e, sobretudo, ao fato de a Central do Resgate encontrar-se em um lugar afastado dos lugares dos quais partem suas viaturas. Estas ficam em vários outros pontos da cidade para poder atender mais rápido, segundo o local da ocorrência. Para a comparação, ambicionada, entre o conteúdo da chamada e a situação encontrada no lugar, a Central do 192 apresentava a grande vantagem de ser, ao mesmo tempo, o lugar de recepção das chamadas (cujo conteúdo podia escutar) e de partida das ambulâncias.

Nessa segunda fase do trabalho de campo, marcada pelo movimento, utilizei bastante a filmadora. Do ponto de vista metodológico, ela representava o instrumento ideal para acompanhar, guardar e restituir a dinâmica da qual participavam os deslocamentos e as ações, para gravar os comportamentos e falas dos protagonistas, para identificar momentos e espaços muito significativos de suas interações. ${ }^{23}$ No fim do trabalho de campo, filmei também com o intuito de finalizar a pesquisa com um documento videográfico sobre a realidade do trabalho efetuado pela Central de Ambulâncias, seus atendentes e motoristas. Este projeto desembocou na realização de Urgences, um documentário etnográfico, cuja proposta central é mostrar para que tipo de problemas ou de situações as pessoas recorrem ao 192 e, através dos vários casos apresentados, desvendar sua concepção da urgência.

\section{NOTAS}

1 Alto Cafezal e Vila Barbosa, criados em 1923, e Marília, criado em 1928.

2 Dados do Censo Demográfico de 2000 da Fundação Instituto Brasileiro de Geografia e Estatística (IBGE). A taxa de urbanização é de $96,14 \%$, a taxa de alfabetização, de $93,9 \%$, e a taxa de crescimento populacional, de 2,32, entre 1991 e 2000.

3 Todos os dados tratados neste livro se reportam ao período da realização do campo.

4 É classificada como Posto de Saúde (Unidade Básica de Saúde - UBS), a unidade destinada a prestar assistência sanitária de forma programada a uma população determinada, por pessoa de nível médio ou elementar, utilizando técnicas apropriadas e esquemas padronizados de atendimento. é classificada como Centro de Saúde, a unidade destinada a prestar assistência sanitária de forma programada a uma população determinada, nas quatro especialidades básicas. A assistência médica deve ser permanente e prestada por médicos generalistas e/ou especialistas.

5 Cadastrados no Sistema de Informações Ambulatoriais do Sistema único de Saúde (SIA/SUS): seis de patologia clínica, três de radiologia, três de ultra-sonografia, três de endoscopia, um de dispensação de órtese e prótese, dois de tratamento dialítico e cinco de fisioterapia.

6 Quando perguntei ao bombeiro que atendia as chamadas na Central o significado de 'canela', ele deu risada e comentou que quem tinha escrito isso era um ignorante, pois 'canela' é uma palavra popular que não deveria ter usado. 
7 Em relação a essa ocorrência, o mesmo bombeiro comentou: "é muito raro o Resgate fazer isso, deve ser alguém que conhece alguém, que tem o poder de obter coisas dos bombeiros, que fez essa chamada".

8 O Projeto Alfa foi fundado em 1990, quando o Ministério da Saúde elaborou um Programa de Enfrentamento às Emergências Médicas. Em Marília, ele é composto pelo corpo docente do curso de medicina e enfermagem da Famema e teve suas diretrizes baseadas em um projeto, de mesmo nome, originário da cidade de Santos/SP.

9 A Central possui mais ambulâncias, mas, durante o dia como à noite, só funciona com três. Devido a problemas mecânicos que ocorrem freqüentemente com esses veículos, não é raro a Central funcionar com duas ambulâncias e às vezes com uma só. $\mathrm{Na}$ época da pesquisa de campo, não havia serviço de suporte avançado de vida (UTI-móvel) público, atendendo o SUS, no município de Marília.

10 Dados coletados nos relatórios semanais, mensais e anuais da Central.

11 Neste caso, o pronto-socorro vem a se tornar o lugar não da primeira, mas da última etapa do processo.

12 Ver o mapa do pronto-socorro no final em anexo.

13 Por autorização oficial do próprio hospital.

14 Em relação a mim: frieza, distância, rapidez das interações, contatos evitados, interrupçăo das conversas ao chegar, trocas e encontros fugazes de olhares... Sobretudo no início do trabalho de campo, penso ter também suscitado modificações nas atitudes, por exemplo, na maneira de certos médicos e enfermeiros se relacionarem com os pacientes ou os acompanhantes. A comparação com observaçōes ulteriores confirmou a impressão que estavam mais disponíveis, atentos e pacientes com as pessoas que procuravam conversar com eles, quando eu estava por perto.

15 O que não tem nada de excepcional, na medida em que como apontam também Beaud e Weber (1997: 10), no "mundo dos dominantes (empresários, profissões liberais, médicas, intelectuais etc...), o trabalho de campo é difícil, pois as pessoas sabem se proteger melhor do olhar próximo do antropólogo, seja dificultando o acesso ao campo, seja aceitando formas mais controladas de colaboração".

16 Com o desenrolar do trabalho de campo, que tornou minha presença mais costumeira, a auto-vigilância, difícil de ser mantida por muito tempo, baixou; o que me permitiu ouvir falas e observar situações, interações e atos, mais próximos do que são em situação 'habitual'.

17 Conversar com os seguranças e porteiros que ficavam parados horas em pé no mesmo lugar (ao lado das portas) não representava uma atitude esquisita na medida em que é bastante comum os usuários, na espera, conversarem com eles também. Com alguns seguranças, as conversas aconteceram também fora do pronto-socorro em lanchonetes que rodeiam o hospital, depois do horário de trabalho.

18 Sem aprofundar aqui essa postura metodológica, pois leva a discussões que fogem de nosso assunto, importa deixar claro que as entrevistas foram voluntariamente pouco utilizadas nesta pesquisa, por serem um instrumento de coleta dos dados de 
discurso muito problemático, no que diz respeito ao conteúdo e à interpretação das respostas (os enunciados) que suscita.

19 Mas filmei a parte de fora na segunda fase do trabalho de campo, quando chegava ao pronto-socorro com as ambulâncias do 192.

20 Também interessava presenciar as reações e comentários dos atendentes depois das ligações.

21 Como é mobilizado e acionado, desde o seu desencadeamento através da chamada de urgência, até a entrega do paciente transportado ao pronto-socorro; quem são os vários atores que atuam nele (motoristas, bombeiros, polícia) e suas relações.

22 Descrição da situação de risco e dos sintomas do doente, identidade declarada do solicitante, nível de angústia etc.

23 Por exemplo, o momento da negociação entre motoristas e solicitantes, que acontece geralmente na chegada da ambulância, no portão de entrada das casas, longe da pessoa para quem o 192 foi chamado. 



\title{
3 \\ Etnografia da Triagem
}

\section{Ambicüidade dos Prontos-socorros}

\begin{abstract}
Como apontam, com justeza, Dodier e Camus (1997a: 109), os prontos-socorros dos hospitais públicos são caracterizados por uma forte ambigüidade:

de um lado, são totalmente abertos aos pedidos exteriores, visto que, em princípio, devem poder acolher o público de maneira permanente e que todos os pedidos de atendimento hão de ser examinados; de um outro lado, e especialmente nos hospitais universitários, os prontos-socorros são lugares seletivos, dado que são concebidos em prioridade para um leque circunscrito de patologias essas suscetíveis de levar à morte ou a lesões irreversíveis se não forem atendidas muito rápido.'
\end{abstract}

A ambivalência dos prontos-socorros também é assinalada por Joseph (1998: 163), quando, em um artigo sobre as urgências psiquiátricas, ele assinala que "as urgências ora designam sintomas que engajam um prognóstico vital, ora traduzem a acessibilidade de um sistema de atendimento à saúde a todos os usuários que se apresentam". ${ }^{2}$

Essa ambiguidade notada pelos autores, por ocasião de pesquisas realizadas na França, verifica-se nos prontos-socorros dos hospitais públicos brasileiros. Aliás, não está presente somente nesses lugares, mas no conjunto dos diversos serviços oferecidos pela rede pública de atendimento às urgências/emergências, tais como as centrais de chamadas e os serviços móveis de ajuda de urgência (viaturas de bombeiros, ambulâncias). A urgência remete a duas noções dualistas: uma que diz respeito a um princípio de acessibilidade garantido a todos, isto é, qualquer indivíduo que pede um atendimento de urgência deve poder ser atendido a qualquer hora do dia e da noite, curtocircuitando as etapas preliminares que atrasariam o seu atendimento; a outra diz respeito a um princípio de especialidade e seleção, pois os diversos profissionais que atuam no domínio da urgência estão preparados, ou se formando, para atender um conjunto delimitado de patologias, ou situações de saúde, consideradas 'urgências verdadeiras'.

A coexistência desses dois princípios de abertura e de seleção está na raiz de uma tensão cujas traduções concretas podem ser observadas nos comportamentos e nas reações daqueles que, atuando na rede do atendimento às urgências/emergências, 
enfrentam um fluxo de pedidos que chegam sob formas heterogêneas e que dizem respeito a problemas de natureza muito diversa, e daqueles que, na busca de um alívio para seus sofrimentos, solicitam um atendimento de urgência.

As manifestações dessa tensão se deixam observar, especialmente, nas interações entre essas duas categorias de pessoas e na maneira como os pacientes são encarados, triados e tratados até o atendimento no pronto-socorro.

\section{Percursos dos Usúrios e Agentes da Triagem}

Ao contrário dos usuários que o sociólogo Jean Peneff (2000:10) encontrou nos prontos-socorros dos hospitais públicos que estudou na França, "pouco homogêneos em suas características sociais" e constituindo "populações heterogêneas", os usuários do pronto-socorro do Hospital das Clínicas de Marília são, em sua maioria, "pacientes SUS", pertencendo às camadas sociais inferiores, com baixo nível de renda e de educação.

Os percursos que eles seguem até conseguir um atendimento, assim como os agentes da triagem que encontram em seu caminho, são diversos. Existem várias maneiras de eles chegarem ao pronto-socorro - a pé, de ônibus, de automóvel,,$^{5}$ de ambulância da prefeitura, de viatura de bombeiros ${ }^{6}$ - e delas depende, em grande parte, a configuração de seus percursos e as modalidades de seu atendimento.

\section{Chiecar a Ṕ́, de Carro, de Ônibus:}

\section{A TRIAGEM DOS SECURANÇAS, PORTEIROS E RECEPCIONISTAS}

As pessoas que vão (ou são levadas) até o pronto-socorro a pé, de ônibus ou de automóvel, têm em comum o fato de se apresentarem sem ter passado por nenhuma seleção preliminar:' o motivo da sua vinda e a 'urgência' de seu caso só começam a ser apreciados no momento em que chegam na entrada do pronto-socorro onde encontram um primeiro profissional, o segurança, que, ficando em pé do lado da porta, olha para elas e pergunta-lhes a razão da sua vinda.

"Eu apenas oriento as pessoas que chegam na porta. A nossa função aqui é fazer a triagem", explica um dos seguranças que atuam na entrada do pronto-socorro. De fato, este profissional não-médico está oficialmente encarregado de liberar a entrada no próprio pronto-socorro para quem está no lugar certo, indicar outras entradas do hospital para quem chegou no lugar errado. Compete também a ele vigiar o número de pessoas que penetram no pronto-socorro, pois suas instruções são de não deixar entrar mais do que um acompanhante por paciente. Na prática, ele aplica essa regra de maneira mais ou menos estrita, segundo os pacientes e a afluência. A ele também cabe vigiar as saídas para impedir as de certos pacientes que, levados pela polícia, pelos bombeiros ou motoristas de ambulância, tentam deixar o pronto-socorro antes serem atendidos.

Portanto, do lado de seus encargos oficiais, os seguranças da porta de entrada ainda têm os não declarados que ampliam o conjunto de suas missões. Assim, cabe a eles, implicitamente, manter a ordem dentro e fora da sala de espera. Sua intervenção diante de pacientes manifestando agitação, agressividade ou comportamentos provo- 
cadores é que revelou, no decorrer da pesquisa, claramente sua função repressiva não declarada. Em algumas ocasiões, chegaram a ter atitudes agressivas e até violentas com pacientes. Tratava-se sempre de homens alcoolizados e, aliás, notava-se que a reação das outras pessoas que esperavam atendimento era geralmente de indiferença. De qualquer jeito, mesmo que raramente explicitada em ações, a presença e o papel repressivos desses agentes estão tão bem sugeridos pelo uniforme, que não escapam a ninguém.

O segurança não está formalmente autorizado a se opor à entrada de quem deseja ser atendido, conforme a aplicação do princípio de acessibilidade a todos do pronto-socorro público. Em termos de seleção, seu papel está declaradamente limitado a uma simples triagem do público em relação à sua orientação certa no hospital. Entretanto, no nível das práticas, a observação revela que esse agente sem formação médica desempenha um papel muito significativo na triagem das urgências.

Em primeiro lugar, acontece do segurança impedir a entrada no pronto-socorro de pessoas que procuram um atendimento. Nas situaçôes presenciadas, que foram poucas, tratava-se de indivíduos embriagados ou ainda vistos como 'loucos', segundo as próprias palavras dos seguranças envolvidos. Eles apresentavam comportamentos esquisitos e falas incoerentes ao mesmo tempo em que um estado físico julgado 'bom' por esses profissionais, isto é, bom o suficiente para eles acharem que não necessitavam de uma consulta no pronto-socorro e, por conseqüência, lhes barrarem a entrada: aos "bêbados", porque iriam arrumar confusão na sala de espera, e porque "bêbado" como "drogado" "não é doente, é uma escolha", segundo seus próprios comentários; aos "loucos", porque também iriam arrumar confusão e "não são doentes", isto é, não padecem de nenhum mal físico. Voltaremos a esse ponto em um capítulo posterior, mas sua simples evocação no momento já demonstra o quanto as representações da urgência, os preconceitos e julgamentos morais dos seguranças podem se traduzir, concretamente, por comportamentos que os levam a desempenhar um papel importante na triagem das pessoas que se apresentam na porta do pronto-socorro.

Em segundo lugar, o caminho que o segurança aponta para as pessoas que querem ser atendidas no pronto-socorro depende da breve avaliação que ele faz de seu estado de saúde. Esta é baseada em dados orais fornecidos pelos pacientes (e/ou os acompanhantes) e em sinais visuais que ele lê no seu corpo e comportamento. A fala da pessoa que quer entrar é suscitada pelo próprio "pois é?" do segurança que, sob essa forma indireta, a interroga sobre seus motivos. Geralmente a resposta que consegue é breve e mínima. Limita-se a frases curtas do tipo: "passei mal", "é para consulta", "tenho dor", "me sinto adoentado". Entretanto, o segurança não insiste e libera a entrada. $\mathrm{Na}$ porta do pronto-socorro, quem chega está geralmente pouco disposto a falar com o segurança: quer entrar. Aliás, contar-lhe suas razões e problemas é exporse a outros desconhecidos, pois a entrada do pronto-socorro é um lugar onde se encontram muitas pessoas, pacientes e acompanhantes em situação de espera.

Em função de sua apreciação do estado de saúde do paciente, a partir das informações que consegue oralmente e, sobretudo, visualmente, o segurança o encaminha para a recepção, onde tem de preencher sua ficha de entrada, ou direto para a área de atendimento médico. ${ }^{8} \mathrm{O}$ primeiro encaminhamento representa a situação mais co- 
mum: é esse que o segurança indica para as pessoas que, segundo ele, podem esperar. Mas se o problema do paciente the parece urgente, ele o leva a curto-circuitar o conjunto das etapas do processo comum, apontando-lhe, com um gesto da mão, a direção da área de atendimento médico onde se encontra um outro segurança, ou um porteiro, que guarda a porta de separação, geralmente fechada, entre essa área e a sala de espera.

Compartilhando ou não a apreciação do primeiro segurança, o segundo tenta ou impede a entrada do paciente na área de atendimento médico. Quando julga não ser urgente o problema do paciente a ele encaminhado, manda-o preencher sua ficha e mostra-lhe a recepção. Muitas vezes observei situações em que os pacientes são objeto de ordens contraditórias dos seguranças e porteiros - mandados para lá, mandados para cá. No próximo capítulo há a descrição e a análise de uma delas. Trata-se de situações que seriam cômicas, se não fossem tão penosas para quem está angustiado e sofrendo. Em compensação, se o segundo segurança também fica convencido da urgência do caso, pede para o paciente esperar e entra na área de atendimento à procura de um médico (ou residente de medicina) no intuito de chamar sua atenção e de incitálo a sair da área de atendimento para vir "dar uma olhada" naquele paciente.

Mesmo não tomando a responsabilidade da entrada direta do paciente na área médica, pois larga a decisão na mão de um especialista médico, o segundo segurança (ou o porteiro) não deixa de ter, então, uma influência notável na triagem porque assinala a existência de um paciente a médicos e enfermeiras ${ }^{9}$ que, por ficarem dentro de um lugar fechado e irem pouco à sala de espera, sabem muito pouco do que existe e acontece nela. Estes tomam conhecimento dos pacientes a serem atendidos após a leitura das fichas que as recepcionistas depositam, periodicamente, ou em uma caixa de madeira na sala de espera, fixada na parede ao lado da entrada da pequena sala de 'triagem clínico geral' (fichas dos pacientes chamados nessa sala), ou em uma caixa que fica dentro da área de atendimento médico (fichas dos pacientes atendidos por especialidades).

Quando, uma vez fora da área de atendimento, e depois de dar uma olhada e conversar brevemente com o paciente (e/ou seus acompanhantes), o médico também fica convencido da possível urgência de seu caso, ele o leva para dentro da área onde será atendido mais ou menos rápido, em função, entre outras coisas, da avaliação mais fina do grau de urgência de seu caso, do número de pessoas que já estão sendo atendidas e da ordem de prioridade na qual vai estar inserido na lista dos que já estão esperando. Em compensação, quando, ao contrário do segurança, o médico avalia o estado/problema como não urgente, ao paciente é solicitado que preencha uma ficha $\mathrm{e}$ espere sua vez. Dependendo do que for indicado pela recepcionista na ficha desse paciente, a partir das respostas que ela obtém sobre o motivo de sua vinda, ele será chamado na pequena sala de 'triagem clínico geral' ${ }^{10}$ ou na área de atendimento.

Aliás, as recepcionistas também desempenham um papel significativo na triagem dos pacientes. Quando estimam que um paciente se encontra em um estado possivelmente grave - por falarem com ele e o verem no momento em que se apresentam para fornecerem os seus dados - elas também avisam ao médico no momento em que vão depositar as fichas nas caixas. A intervenção das recepcionistas, como a dos seguranças e a dos porteiros, pode traduzir-se em um tempo menor de espera pelo paciente que conseguiu chamar a sua atenção. 


\section{Valor Mobilizador dos Pacientes}

Como se pôde observar, existem dois percursos para os pacientes que, vindo a pé, de ônibus, de carro, conseguem sua entrada no pronto-socorro: ou seguem o caminho da maioria e preenchem sua ficha para depois esperar pelo atendimento na sala de espera, ou curto-circuitam todas as etapas, obtendo a entrada direta na área médica onde recebem um atendimento que pode, ou não, ser imediato.

Para conseguir percorrer o segundo caminho, o paciente tem de estar em um estado apreciado como urgente por profissionais que não têm nenhuma formação médica (os seguranças, porteiros, recepcionistas) e que nem sempre concordam na avaliação; é só no final que ele é visto por um médico que decide sobre o grau de urgência de seu caso. Isso significa que para tomar o caminho mais rápido o paciente tem de convencer várias categorias de profissionais (não médicos e médicos) que, em face das diferentes determinações socioculturais das camadas de população às quais pertencem e das diferentes profissões e competências que exercem, certamente não compartilham o mesmo conhecimento nem o mesmo universo de representação do que remete à saúde, em geral, e à urgência e à emergência em saúde, em particular.

O que possuem os pacientes que perfazem o segundo caminho em relação aos que são encaminhados para o primeiro? Eles têm o que Dodier e Camus (1997a: 113) chamam de um "valor mobilizador alto". O pessoal que atua no atendimento às urgências e emergências (seguranças, porteiros, recepcionistas, enfermeiras, médicos, mas também motoristas de ambulâncias, bombeiros) reage por uma mobilização diferenciada segundo os pacientes. Cada paciente adquire um valor mobilizador mais ou menos grande que se traduz de maneira concreta na triagem pelo lugar que lhe é atribuído na hierarquia e na ordem das prioridades. Maior a força mobilizadora de seu caso, menor o tempo de espera até o atendimento. Assim, os pacientes que têm o valor mobilizador mais baixo - os que Dodier e Camus (1997a: 115) chamam de pacientes "tolerados"são os que mais aguardam a sua vez. Aliás, não é raro o pessoal do pronto-socorro acabar se livrando deles justamente pela duração da espera: desistindo de serem atendidos, acabam indo embora, geralmente muito descontentes e magoados.

Os critérios nos quais os vários profissionais do pronto-socorro se apóiam para hierarquizar o valor mobilizador dos pacientes são de ordens distintas. Será feito seu exame nos capítulos voltados à questão de suas representações da urgência e da emergência.

\section{Ciegar com o 192 ou 0 193:}

\section{A TRIAGEM DOS MOTORISTAS DE AMBULÂNCIA E BOMBEIROS}

À diferença dos pacientes que vão ao pronto-socorro a pé, de carro ou de ônibus, os que chegam de ambulância ou de viatura de bombeiros já passaram por várias avaliações de seu estado de saúde quando chegam à porta do pronto-socorro.

Trazidos pelos bombeiros ou motoristas de ambulância, eles têm garantida sua entrada no pronto-socorro. O segurança não os interroga sobre os motivos de sua vinda nem aos profissionais que os acompanham: deixa-os passar. É que, quando chegam, 
esses pacientes já estão no final de um primeiro percurso ligado a um primeiro processo de seleção que teve início fora do pronto-socorro. Na fase que antecede sua chegada, eles já convenceram os diversos profissionais que os auxiliaram até o pronto-socorro. Persuadiram-nos não necessariamente da urgência (ou emergência) de seu caso, mas conseguiram, pelo menos, convencer de sua possível seriedade o atendente das centrais de chamada (192 ou 193). Antes de chegar ao pronto-socorro, eles já passaram, então, por uma triagem realizada, primeiro, pelo atendente que tomou a decisão de mandar um veículo de socorro e, depois, pelos profissionais, motoristas de ambulância ou bombeiros que foram buscá-los.

Uma vez enviadas, as equipes de ajuda móvel são obrigadas, por questões de responsabilidade, a atender a pessoa objeto da chamada e a levá-la para o prontosocorro, qualquer que seja a avaliação feita uma vez no lugar; isto é, mesmo se são levadas a apreciar o estado (situação) de saúde do paciente como menos sério (e até não sério) do que o descrito no telefone, como acontece muitas vezes. ${ }^{11}$ Contudo, nem por isso, sua avaliação deixa de ter incidência sobre a triagem, pois em função dela, tanto os bombeiros do 193 quanto os motoristas do 192 agem com 'mais' ou 'menos' rapidez até a entrega do paciente no pronto-socorro; também passam a informaçăo da urgência ou não do caso que estão levando para o segurança da porta de entrada do pronto-socorro, induzindo, assim, a maneira como o paciente que transportam vai ser considerado e tratado na chegada, como será visto a seguir.

Para os pacientes que vão ao pronto-socorro de veículos móveis de ajuda médica urgente, a triagem comę̧a, então, bem antes de eles serem examinados por um médico. Ela se inicia na dependência das apreciações dos profissionais das centrais - atendentes, motoristas, bombeiros - e continua no pronto-socorro, onde, em função das apreciações de outros profissionais não médicos, os pacientes são levados a percorrer um dos dois caminhos descritos anteriormente.

Por iniciativa dos próprios motoristas das viaturas e ambulâncias, o segurança da entrada recebe informações sobre a gravidade do caso, antes de o paciente passar pela porta. Existem códigos gestuais entre ele e os motoristas. Quando estão ainda subindo a rampa de acesso ao pronto-socorro, estes usam de sinais para indicar o grau de urgência com que seu paciente tem de ser atendido, uma vez o veículo parado na porta do pronto-socorro. Se o motorista, através do pára-brisa, faz o gesto de erguer um dedo, é que o caso do paciente que está levando é, segundo os seguranças, "urgente". Vendo esse sinal, o segurança da entrada se dirige a uma campainha que se encontra perto dele na sala de espera, ${ }^{12} \mathrm{e}$ a toca apenas uma vez, avisando a equipe médica da chegada de uma 'urgência'. Se o motorista mostra dois dedos, ou se dá o sinal de luz ou ainda um toque de sirena, é que se trata de uma 'emergência', que exige uma intervenção rápida da equipe médica. Neste caso, o segurança avisa tocando a campainha duas vezes. Enfim, se o motorista não faz nenhum gesto, é que seu paciente não precisa de atendimento urgente na chegada, segundo a avaliação dos que o transportam.

É nessa terceira categoria que se encaixa a maioria dos pacientes que chega de ambulância da prefeitura e de viatura do Resgate: seu estado de saúde não é julgado "urgente" pelas equipes de socorro . Entretanto, são geralmente atendidos mais rápido do que os que chegam a pé, de ônibus, de carro particular. Essa constatação se verifica 
ainda mais freqüentemente no caso dos pacientes trazidos de viatura pelos bombeiros que, muitas vezes, conseguem uma entrada imediata na área de atendimento médico, acompanhados por bombeiros que foram buscá-los. Ainda mais rápido é o atendimento se, ao sair da viatura, eles não entram andando, mas deitados em uma maca. A mesma observação pode ser feita em relação aos pacientes trazidos por ambulâncias do 192 (da prefeitura), apesar de estes serem, geralmente, levados menos a sério pelo pessoal que atua no pronto-socorro do que aqueles que chegam com bombeiros.

Essa última constataçāo aponta para a menor credibilidade das ambulâncias da prefeitura em comparação com as viaturas do corpo de bombeiros, no que diz respeito à urgência e à gravidade dos casos que transportam para o pronto-socorro. $\mathrm{O}$ valor mobilizador que adquire um paciente pelo simples fato de chegar com os bombeiros se deixa ler tanto nas atitudes e comentários das pessoas que esperam na sala de espera, quanto nos comportamentos do pessoal que trabalha no pronto-socorro. As primeiras fixam a viatura quando chega, e o ambiente torna-se mais tenso na espera do paciente que vai sair. Uma vez fora da viatura, elas o acompanham com o olhar, à procura de sinais confirmando a gravidade de seu estado. Seus comentários - "o que chega de bombeiros é grave", "é urgência mesmo" - também evidenciam que, na concepção do público, quem chega de viatura do Resgate está potencialmente em um estado muito sério. $\mathrm{E}$ isso mesmo se, muitas vezes, os pacientes trazidos pelo Resgate não são considerados "urgentes" pelos próprios bombeiros, assim como eles comentam e, aliás, lamentam. Quanto ao pessoal que atua no pronto-socorro, particularmente o da enfermagem, mostram-se mais disponíveis e rápidos quando se trata de ir buscar um paciente que chega com os bombeiros, do que um que chega de ambulância ${ }^{13} \mathrm{ou}$, ainda pior, que chega de carro particular. Neste último caso, o segurança geralmente nem toca a campainha, qualquer que seja o estado do paciente e a necessidade de ajuda.

A maior credibilidade do Resgate em comparação com as ambulâncias do 192 explica-se por vários motivos. É que aquele geralmente presta socorro nos acidentes de trânsito e, por consequiência, leva para o pronto-socorro as vítimas mais espetaculares em termos de ferimentos aparentes. No espaço público, os bombeiros têm também uma visibilidade bem superior a dos motoristas de ambulâncias, quer seja pelo barulho de suas sirenas, pela cor vermelha e a aparência imponente dos seus veículos, quer seja por seu uniforme e sua freqüente atuação nas vias públicas. Enfim, eles contam geralmente com uma fama muito boa entre a população, que elogia a eficácia e a rapidez do socorro por eles prestado. Mesmo desfrutando de uma credibilidade invejável, os bombeiros do Resgate lastimam sua diminuição progressiva no meio médico e incriminam a demanda. Assim, segundo eles, os médicos dão menos atenção hoje aos pacientes que levam para o pronto-socorro porque o Resgate é cada vez mais chamado para atender casos que não são "emergências", o que se traduz por uma desvalorização de sua atuação. "Antes era uma beleza, hoje os médicos não dão bola, nem saem mais", diz um bombeiro que assim expressa a perda de credibilidade sentida por muitos. E, de fato, médicos do pronto-socorro se queixam dos bombeiros: "eles atendem qualquer pedido, não tem triagem" é um comentário comum.

O que dizer então do 192, cujos motoristas e ambulâncias sofrem de uma desconsideração que se estende até aos pacientes que transportam? Atendendo muitos 
casos não considerados como emergências nem urgências pelos profissionais, médicos e não-médicos, as ambulâncias levam ao pronto-socorro muitos pacientes que, dentro das próprias categorias utilizadas pelos motoristas, bombeiros, enfermeiros e médicos, são ditos "casos sociais" e "casos psiquiátricos". Também levam muitos "casos clínicos" que não apresentam sinais de gravidade aparente, em outros termos, casos não espetaculares. Além disso, servem para o transporte inter-hospitalar e, sobretudo à noite, para o transporte de pacientes que, uma vez atendidos no pronto-socorro, não têm como voltar para casa. Enfim, elas sofrem de uma desconsideração que diz respeito não imediatamente ao 192, mas à saúde pública, a qual são, com justeza, assimiladas.

A imagem negativa que os usuários têm do atendimento público também envolve as ambulâncias. Aliás, essa observação pode ser generalizada à população em geral. A representação positiva do Resgate em contraposição à negativa das ambulâncias se traduz, por exemplo, por comportamentos muito diferenciados na rua. Tendo acompanhado motoristas de ambulância e bombeiros nas suas saídas, notei os comportamentos diferentes dos motoristas - de carros particulares, ônibus e caminhão - quando o veículo de socorro que pedia a passagem era o do Resgate ou do 192: no primeiro caso, esforçavam-se geralmente para liberar a via; no segundo, não faziam nada, simplesmente ignoravam a ambulância. Claro que a potência das sirenas do Resgate, a autoridade militar que representam os bombeiros, assim como o poder que detêm, agem no sentido de coagir os motoristas, e essa pressão os motoristas de ambulâncias não têm condição de exercer. Mas não é só isso: os primeiros são levados bem mais a sério do que os segundos, seu trabalho e os pacientes que transportam também.

\section{LIGAR PARA 0192 OU 0193 :}

\section{A TRLAGEM DOS ATENDENTES}

Voltando à questão da triagem dos pacientes que chegam ao pronto-socorro com os bombeiros do 193 ou com os motoristas do 192, importa sublinhar o quanto é crucial a avaliação feita de seu estado (ou situação) de saúde pelos atendentes das centrais, pois a decisão de "soltar um veículo" e o momento escolhido para fazê-lo dependem deles. Sua apreciação é que desencadeia todo o processo de ajuda e de triagem. Aliás, muitos solicitantes estão cientes disso, pois recorrem a vários estratagemas para conseguir a vinda - e não só a vinda, mas a vinda rápida - de um veículo, assunto que será abordado mais adiante.

Um momento decisivo da triagem se dá, então, no telefone. Os atendentes não são profissionais da saúde e nem todos receberam uma formação de pronto-socorrismo. A partir das perguntas que fazem aos solicitantes, tentam orientar a conversa de maneira a obter informações sobre vários pontos, entre os quais, a identidade do solicitante e da pessoa para quem liga, o problema de saúde que motiva a chamada e o lugar aonde mandar a ambulância. ${ }^{14} \mathrm{~A}$ maioria dos solicitantes muitas vezes nem pertencem à família do paciente. Não é raro eles falarem que desconhecem a pessoa objeto de sua solicitação, mas geralmente dizem ser vizinhos ou conhecidos, ${ }^{15}$ o que dificulta bastante $o$ trabalho do atendente, pois muitos deles ignoram tanto o nome da pessoa a socorrer quanto o que está acontecendo com ela. 
Quando, no final de sua conversa com o solicitante, o atendente recolheu informações que o levam a pensar, primeiro, que a chamada é séria, e, segundo, que o estado de saúde descrito é grave ou pode vir a se tornar como tal se nada for feito, ele libera uma ambulância. Esta não sai necessariamente de imediato. Depende de ter uma disponível no momento da chamada e também se há solicitações anteriores ainda não atendidas, $o$ atendimento deste pedido vai ser inserido na ordem das prioridades, segundo a apreciação de seu grau de urgência.

Os atendentes não liberam um veículo só para os casos que julgam urgentes ou emergentes. Mais adiante será visto que, muitas vezes, "na dúvida", como eles mesmos dizem, preferem mandar do que ser responsabilizados mais tarde, e com eles a Central, por não ter mandado. Essa constatação se verifica sobretudo na Central de Ambulâncias, pois a do 193 é mais seletiva. Esta faz a triagem dos tipos de urgências a serem atendidos pelo Resgate - a saber, principalmente, os que decorrem de acidentes (de carro, atropelamentos, quedas) - e encaminha os pedidos que fogem de suas atribuições ${ }^{16}$ para a Central de Ambulâncias, pedindo para os solicitantes ligarem para o 192, pois "seu caso não é dos bombeiros". Em comparação, a Central de Ambulâncias parece com o gargalo de um funil para o qual acabam convergindo muitos pedidos de ajuda que não foram atendidos por outras instâncias, tais como o Resgate, o Bem-Estar Social ${ }^{17}$ e a Polícia Militar. Ela está sobrecarregada com uma demanda que a afasta, de maneira considerável, de sua função declarada.

Assim, a triagem do 192 se efetiva menos na seleção dos casos a serem atendidos - porque, afinal, a maioria das chamadas recebe uma resposta favorável ${ }^{18}$ - do que no tempo da demora até o atendimento ser prestado. Nesse ponto, a Central parece muito com o pronto-socorro. É comum os atendentes responderem positivamente a uma chamada para um problema que não acham urgente, acrescentando "vai demorar porque não tem ambulâncias no momento"; mesmo, aliás, se sobrar uma, pois reservam a ambulância ainda disponível para uma eventual urgência/emergência.

No 193, a situação é inversa: a triagem se realiza mais na seleção dos casos que são atendidos (e, por essa razão, as saídas das viaturas do Resgate são bem menos numerosas) do que no tempo que levam as viaturas para chegar no lugar, pois, de maneira geral, é breve, uma vez que o pedido do solicitante recebe uma resposta favorável por parte do atendente.

\section{Ем Suma...}

Todas as categorias de profissionais anteriormente citados, mesmo que, em sua maioria, não médicos, participam da triagem das ditas 'urgências/emergências médicas', cada um em seu papel, cada um em seu lugar. A interdependência e a interligação de suas apreciações e avaliações desenha uma corrente dinâmica de decisões e ações que, afinal, determina a qualidade dos cuidados e do socorro prestados em termos de rapidez e eficácia.

Para os usuários, essa corrente é um percurso, mais ou menos longo, demorado e diversificado. Até chegarem ao destino final e receberem a ajuda e os cuidados médi- 
cos esperados ou impostos, passam por várias etapas. Alguns, aliás, não atingem o destino final, seja porque desistem no caminho - ficando em casa ou voltando para ela -, seja porque se recusam a embarcar ou ainda morrem antes de chegar. Para quem a faz, essa viagem tem implicações e traduções muito práticas e concretas.

As observaçöes de campo revelam que, dito de maneira um tanto caricatural e provocadora, a melhor maneira de conseguir um atendimento rápido no pronto-socorro é chegar de viatura de bombeiros, deitado em uma maca (mesmo que consciente), apresentando alguma marca impressionante visível no corpo, como sangue, feridas e fraturas expostas... O conjunto desses sinais heterogêneos garante a entrada imediata na área de atendimento médico, qualquer que seja o estado de saúde do paciente, só avaliado depois por médicos. O contrário acontece com quem chega por meios próprios, passa em pé pela porta do pronto-socorro, e se queixa de algum problema que não apresenta nenhum sinal manifesto no corpo ou no comportamento: este paciente tende a esperar sua vez, até por muito tempo, sobretudo se fica quieto, sentado na cadeira. A não ser se ele de repente desmaiar: neste caso, seu atendimento torna-se imediato.

As avaliações dos vários agentes da urgência/emergência - cujas decisões e ações impulsionam sua dinâmica e sua configuração aos percursos dos usuários - são informadas a partir de um conhecimento diverso constituído, com o tempo, através da aquisição teórica ou/e empírica de certos elementos de conhecimento médico, e outros decorrentes de sua vivência e de experiência de sua função. Suas apreciaçōes se embasam em representações da urgência/emergência que são importantes apreender para entender suas práticas, e é precisamente a partir da observação minuciosa e perseverante dessas práticas que as representaçôes dos atores da urgência/emergência podem ser atingidas, em um balanço comparativo com os discursos por eles proferidos.

O que é uma urgência, uma emergência, o que é considerado grave, o que suscita a mobilização por parte dos médicos, dos seguranças, porteiros e recepcionistas, dos motoristas de ambulância e atendentes das centrais? E por parte dos usuários? É a essas perguntas que os próximos capítulos ambicionam responder.

\section{Notas}

1 Tradução livre.

2 Tradução livre.

3 Trata-se dos prontos-socorros de três hospitais da Assistência Pública de Paris (AP): Beaujon (Clichy), La pitié-Salpétrière (Paris) e Ambroise-Paré (BoulogneBillancourt).

4 Empresto aqui uma expressão corrente entre os profissionais do pronto-socorro.

5 Carro pessoal, da família, dos vizinhos, de conhecidos, táxi...

6 Mais raramente, alguns também chegam de carro de polícia: trata-se geralmente de presos e, às vezes, de pessoas que a polícia recolheu na rua.

7 Exceto se foi encaminhada por um médico particular ou de um posto de saúde, o que é o caso de poucas. 
Ver o mapa do pronto-socorro em anexo.

9 Os motoristas de ambulância agem da mesma maneira quando levam ao prontosocorro um paciente grave, segundo sua avaliação.

10 Se tiver um médico atuando na triagem, o que não é sempre o caso, mesmo durante o dia.

1 Quando as equipes móveis não levam para o pronto-socorro um paciente que foram buscar é porque este fugiu antes de sua chegada ou se recusa a ir e atesta, por escrito, sua recusa (ou alguém de sua família, se ele é julgado incapaz de se pronunciar ou de decidir por ele mesmo).

12 Ver o mapa do pronto-socorro em anexo.

13 Isso, quando enfermeiras se deslocam para ir buscar na entrada pacientes que chegam de ambulância. Porque mesmo no caso dos que precisam de ajuda, como, por exemplo, de uma cadeira de rodas, é comum o próprio motorista, ajudado pelo segurança, cuidar deles, e acabar levando-os para dentro do pronto-socorro porque ninguém da enfermagem se apresenta.

14 Exemplos dessas conversas serão dados em um capítulo posterior.

15 Voltaremos a este ponto posteriormente.

16 Geralmente os que os bombeiros chamam de "caso psiquiátrico", "caso social" e "caso clínico", exceção feita ao enfarte.

17 Trata-se de um serviço social da prefeitura que funciona só de dia e possui uma ambulância que serve para o transporte das pessoas (inter-hospitalar, para fazer exames, levar os pacientes para casa etc).

18 Com exceção, claro, dos pedidos incompletos, no que diz respeito às indicações de localização (rua, número) e dos inúmeros trotes e enganos recebidos pela Central. 



\section{"Tem Fratura Exposta? Artéria Babando?": a perspectiva dos profissionais da saúde}

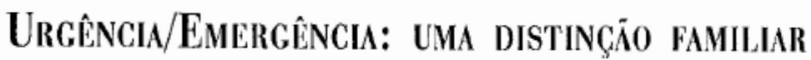

Os médicos, enfermeiros e residentes que atuam no pronto-socorro se referem, com recorrência, à distinção entre urgência e emergência. Em nossas conversas, e mesmo quando não interrogados a seu respeito, eles insistiam muito sobre a importância dessa distinção, chegando, por exemplo, a classificar espontaneamente os casos por eles relatados na categoria das 'urgências' ou das 'emergências'. Já vimos, aliás, o quanto essa discriminação se faz presente na fala dos profissionais da saúde quando, lamentando a ignorância da população, criticam sua incapacidade de diferenciar essas duas categorias de urgências. Eis alguns trechos que exemplificam a referência comum a essa distinção nos discursos:

Oitenta, oitenta e cinco e até noventa por cento não são urgências. A criança vomitou uma vez, ou ela tem um pouco de febre, a mãe já leva para o PS. A população não distingue a urgência da emergência. A gente diz para ela vir quando a criança está com febre. Mas para eles a criança tem uma febrezinha. um $39^{\circ}$, é urgente. Para mim, médico, a febre é um sinal de alerta que pode se tornar um sinal de urgência se ela vem acompanhada com vômitos. (Médico atuando na triagem clínica infantil)

Tem que distinguir a urgência relativa, que são nove dos dez casos que atendi desde de manhã, da urgência absoluta. A urgência absoluta não é emergência. A urgência relativa pode se transformar em uma urgência absoluta que pode vir a ser uma emergência. Tem uma diferença entre as três. (Médico do pronto-socorro)

Urgência são os casos que necessitam ser atendidos, mas sem risco de vida. Emergência são os casos com risco de vida iminente. (Médica do pronto-socorro)

Uma criança com bronquite, cansada, cianose de lábios: é uma urgência. Um baleado, alguém sangrando, um acidente: é uma emergência. Os dois podem vir a morrer. Mas, no caso da criança, sabemos o que ela tem, ela respira normalmente. Enquanto o baleado, não sabemos o que ele tem, não sabemos a repercussão do que ele tem. Se os dois chegarem juntos, atendo primeiro a 
emergência e segundo a urgência. Começamos pelo pior. Certo que o que fica bom pode se tornar pior. (...) Se fosse o meu pai e o meu filho, porque é assim que todos fazem aqui, se eu vejo que meu pai está muito ruim e meu filho melhor, escolho atender primeiro o meu pai. Mas se vejo que o estado do meu filho está também muito ruim, ai eu cuido do meu filho. Opção para quem tem mais chance de sobreviver. (Médico do pronto-socorro)

Falta de ar na linguagem popular, na linguagem médica é dispnéia, é uma urgência, até uma emergência. Desmaio, se for em criança, para mim, é uma urgência, pois a criança não finge. Já no adulto não diria a mesma coisa, eles fingem, dissimulam. (Médico do pronto-socorro)

Na gineco a maior parte não é urgência (...). O parto é uma urgência, até uma emergência. Pode não ser, mas como não tem leito, se torna urgência. Agora, na ortopedia, tudo é urgência porque não se sabe se for fratura. (Residente do pronto-socorro)

Emergência é assim: o paciente chegou, inconsciente, tem uma escala de Glasgow, quando é inferior a 8 é que o paciente precisa de uma emergência. Tem que fazer todas as manobras, até fibrilação. Agora a urgência, por exemplo, tem um acidente, o paciente chega com ferimentos leves, não tem fratura, artéria babando. E tem o eletivo que é $80 \%$ [dos casos]. É febre, dor de garganta, no dedo, na cabeça, contusão, torção. (...) Cólica renal, epilepsia, depende do exame que vai ser feito. A cólica renal pode ser um cálculo pequeno e já acabou. Nesse caso, ela é eletivo. Mas pode ser pielonefrite que pode ser aguda. Isso é emergência porque vai para a cirurgia. A gente segue uma linha assim no atendimento às emergências. Acidentado A, B e C. 'A' é desobstrução de vias áreas superiores. A prioridade é o ar. Ventilou, então pode esperar. (...) O paciente quer a prioridade para uma febre. Não sabe o que é emergência. Na sala de espera eles aguardam e acham que é demais. Não conseguem entender. (Enfermeira do pronto-socorro)

A frequência e a facilidade com que os profissionais da saúde recorrem à distinção entre urgência e emergência testemunha sua familiaridade - característica ${ }^{1}$ - com essas noções e com sua discriminação apresentada como crucial. Urgências e emergências não devem ser confundidas: na avaliação dos estados/situações de saúde e, conseqüentemente, para a realização de atendimentos adequados, é fundamental saber fazer a diferença entre as duas, isto é, saber identificar os casos que 'não podem esperar' e os que 'podem esperar', segundo fórmulas muito usadas pelos próprios médicos e enfermeiros, pois, este é o grande traço diferenciador entre as emergências e as urgências, mesmo se as falas apontam também para diversas variáveis que, extraclínicas, têm incidência sobre essa apreciação (O paciente é uma criança ou é um adulto? É um jovem ou um velho? Tem leitos ou não tem? O prognóstico é favorável ou não?).

Existe um amplo consenso em torno da distinção a ser feita entre essas duas categorias de urgências. Entre os profissionais da saúde, são pouquíssimos os que a colocam abertamente em questão ou, pelo menos, que a discutem. No pronto-socorro estudado, dois médicos mostraram-se críticos. Apesar de partirem de um raciocínio diferente, os dois ficavam inconformados, e até indignados, com essa discriminação 
que julgavam absurda, do ponto de vista do sentido, e condenável, do ponto de vista ético. Representativos das críticas dirigidas a essa distinção, seus argumentos merecem ser examinados.

Fiel à etimologia das palavras, o dr. 1 estima que 'urgência' e 'emergência' não podem constituir duas categorias de urgências na medida em que aquilo que caracteriza uma emergência - que seja um sintoma, um acidente, um estado de saúde - não é sua gravidade, a necessidade de agir sem demora, mas o caráter súbito de sua ocorrência. Ora, o que se manifesta ou acontece repentinamente não apresenta necessariamente um caráter urgente, isto é, não representa ou assinala uma ameaça para a vida que exige uma intervenção médica imediata, como é o caso, por exemplo, de uma dor aguda que se manifesta de maneira inesperada. Nesse sentido, nem toda emergência é urgente.

Da mesma maneira, se a urgência exige uma ação terapêutica indispensável e rápida, ela não necessariamente apresenta um caráter súbito. Nesse sentido, uma urgência pode existir sem emergência, mesmo que apresentando um caráter de extrema gravidade. Por essas razões, a distinção urgência/emergência não tem sentido e não vale para discriminar as urgências do ponto de vista da gravidade, do tempo para agir, da prioridade do atendimento: só se deveria falar em urgências. Na concepção defendida pelo dr. 1, a emergência não caracteriza um grau (alto) de urgência, pois entre a primeira e a segunda não existe relação necessária.

$\mathrm{O}$ dr. 2 se mostra ainda mais severo e radical na crítica que, aí, vira denúncia. Expressão da prepotência dos médicos, a distinção urgência/emergência não só é insensata, mas também perigosa. Eis alguns trechos de sua fala:

Não tem sentido a diferença, acho que tem que ser uma palavra só: é impossivel, desnecessário e inconseqüente essa diferenciação entre emergência e urgência (...). Se imaginar um acidente com crash, tudo é emergente porque... se num acidente automobilistico com pessoas, oprimeiro está conversando, até ajudando o atendimento, esse primeiro é considerado ótimo, mas ele pode estar com uma lesão hepática e sangrando. E o segundo, um paciente sem sentidos - ou por causa do choque emocional ou por causa de uma leve coagulação cerebral --ele pode estar mais ótimo do que o primeiro. Então, num acidente tudo é emergente. Então, aqui principalmente, eu acho um absurdo e até uma omissão se tentar nesse momento, com dados clinicos, tentar diferenciar emergência e urgência... Porque, veja bem... qual é? O médico é muito onisciente, prepotente, acha que este está melhor que aquele, mas que parâmetro que ele tem? O saber técnico resolve? Por exemplo, eu participo... membro inferior, essa artéria está lesada,... digo aneurisma, evidentemente o pulso está presente, o médico palpou e falou 'o pulso está presente, não há lesão arterial'. Se esse médico tivesse feito um exame mais apurado, no minimo obteria um sopro aqui. Mas se fizer a si mesmo essa pergunta 'a presença do pulso exclui lesão arterial?', estou com certeza que a maioria dos médicos responderá que sim, mas não exclui, você pode ter uma lesão parcial (...). Não estamos capacitados, principalmente no atendimento extra-hospitalar, a estabelecer essa diferença. E quanto mais se tenta estabelecer. quanto mais se diz 'é urgência, não é emergência', mais estamos prejudicando ou contribuindo para a não assistência ou a má assistência ou, inclusive, seria até um erro, um desrespeito à vida do paciente. (...) Quem tem um conceito cientifico adquirido através da informação e não do conhecimento - ele foi 
informado, tem que ser assim, não tem nem reflexão-ele [o médico] aplica aquilo que está no livro sem reflexão. (...) Ser cirurgião é ser um técnico independente de ser um médico. Ser médico, qualquer um, se basear-se nos protocolos - esses programas de emergência, os protocolos, graças a Deus, até esqueci o nome do programa que é usado pela emergência! -, pode ser médico independente da faculdade. (...) No PS, naquele instante, não deve existir diferenciação entre emergência e urgência... Então vamos transformar em emergência e dar um pronto atendimento, porque o paciente procurou, e nós, tão-somente pela percepção, não estamos autorizados a protelar esse atendimento, ou mesmo deixar de atender.

$\mathrm{O}$ dr. 2 condena uma distinção que, segundo ele, desemboca em uma discriminação ilegítima - e por isso, eticamente condenável - dos estados de saúde. Tal distinção leva a desconsiderar, de antemão, certos estados de saúde para valorizar outros, a partir de uma apreciação baseada na aplicação geral dos protocolos ensinados nos manuais de emergência que descrevem as etapas dos procedimentos terapêuticos a serem seguidos para os problemas de saúde repertoriados como 'emergências'. Entre outras implicações, conduz ao exame clínico superficial ${ }^{2}$ e ao descaso dos pacientes cujas queixas e/ou sintomas fogem das emergências catalogadas e descritas nesses manuais. Para o dr. 2, como para o dr. 1, só deveria existir a categoria das 'urgência(s)', todas consideradas de antemão como sérias e exigindo um atendimento rápido, até um exame apurado determinar sua gravidade.

\section{Os Sinals}

As observações de campo revelam, de fato que, por existirem duas categorias de urgências, umas consideradas 'graves' (as emergências) e as outras 'menos graves' (as urgências), as primeiras acabam sendo muito valorizadas em detrimento das segundas, que, por não serem tão urgentes, parecem se fundir no conjunto do não urgente, e, afinal, desaparecer como 'urgências'. Na rotina do pronto-socorro é como se, de um lado, estivessem as emergências urgentes, e do outro, o resto: a distinção urgência/ emergência se dissolve, para sobrar só as emergências como urgências verdadeiras, atendidas e tratadas como tal, a saber: com rapidez.

A valorização de um estado de saúde como 'grave', 'urgente' - seu alto valor mobilizador - pode ser identificada, menos graças aos discursos normativos proferidos fora de contexto ${ }^{3}$ - "isso é urgência, isso é emergência" - do que graças à observação dos comportamentos, tais como se manifestam e se dão a ver em situação. Em outros termos, ela pode ser deduzida das atitudes diferenciadas dos médicos e enfermeiros (a equipe médica), assim como do pessoal não médico do pronto-socorro (seguranças, porteiros, recepcionistas), em relação aos pacientes no momento de sua chegada e depois.

Por exemplo, a rapidez ou não do atendimento (tempo de espera), o tipo de percurso seguido pelo paciente, ${ }^{4}$ a ida ou não de um médico ou/e de enfermeiras à sala de espera (sua saída da área de atendimento) para ver ou/e buscar o paciente, o número de 
profissionais de saúde intervindo no momento de sua chegada e depois, a precipitação, o clima de tensão, o nervosismo provocado ou não pela entrada do paciente no prontosocorro, são vários indícios que, observáveis a partir da sala de espera, testemunham a forte, fraca, ou inexistente mobilização da equipe médica em relação a um paciente. São eles que indicam ao observador se um caso é considerado urgente, grave ou não pelos médicos. São eles que revelam o que é contemplado por eles como 'emergência(s)'.

Quais são, então, os sinais que - detectáveis ou não no paciente - suscitam, de maneira notável e significativa, uma forte ou fraca atenção/mobilização por parte dos profissionais da saúde que atuam no pronto-socorro?

\section{Estar Inconsciente ou Deitado}

Qualquer que seja seu problema e qualquer o meio de transporte que os levaram para o pronto-socorro, os pacientes, quando chegam sem consciência (ou desmaiam depois de sua chegada), são atendidos com bastante rapidez. O mesmo pode ser observado com os que entram no pronto-socorro deitados em uma maca: $:^{5}$ conscientes ou não, e qualquer que seja seu estado de saúde (só investigado depois por médicos), eles obtêm uma entrada direta na área de atendimento. ${ }^{6}$ Estar desmaiado ou estar deitado são dois sinais - e, especialmente, a perda de consciência - que suscitam um grau elevado de atenção por parte da equipe médica, pelo menos nos primeiros momentos da chegada do paciente. Considerados como indícios a priori, e por excelência, de uma provável emergência, são levados muito a sério e seu poder mobilizador é alto.

É só observar as reações e ações provocadas pelo desmaio de um paciente na sala de espera, para confirmar a importância dada a essa manifestação por parte do pessoal médico. Presenciei várias situações desse tipo, em que pacientes esperando quietos sua vez de ser chamados, de repente, perdiam consciência. ${ }^{7}$ Seu desmaio provocava a intervenção de seguranças, médicos e enfermeiros que os levavam imediatamente para a área de atendimento. A perda de consciência aumentava de maneira considerável o valor mobilizador desses pacientes, antes fraco, ${ }^{8}$ até eles desmaiarem. Da mesma maneira, a ordem dada ao segurança da entrada para avisar a equipe médica, por meio da campainha, da chegada de alguém de maca testemunha a atenção dada aos pacientes que entram deitados.

Certos pacientes notam a importância dada à perda de consciência pelos médicos, que, cansados com a espera, fazem, brincando ou irritados, comentários como: "tenho que desmaiar para ser atendido!". Entre outros exemplos, escutei essa frase por parte de uma mulher de uns 60 anos, que estava na espera, gemendo de vez em quando, havia três horas, quando começou a conversar comigo, dizendo: "os médicos se esqueceram de mim". Tinha caído no ônibus de manhã cedo e se queixava de muita dor "por causa da costela". "Estou com medo de furar o pulmão e de infectar a carne por dentro", dizia ela. Referindo-se a uma cena presenciada de manhã no pronto-socorro, lançou em voz alta e com ironia: "vou desmaiar para ser atendida!". Contou-me que, algumas horas antes, a mulher que estava sentada ao seu lado desmaiou: "ela diz que tem dor na nuca, formigamento na mão, pressão alta. Falei para a filha dela: a sua mãe vai morrer. De repente, ela diz que tinha problema na vista, chamei um guarda: atenda essa mulher, 
você quer que ela morra? Porque dor na nuca, formigamento na mão e ela com pressão alta!". E terminando seu relato com força, voltou a gritar: "tenho que cair no chão para ser atendida!?".

Apesar de diferentes, essas duas situações altamente mobilizadoras - estar sem consciência, estar deitado - têm em comum que o paciente não anda. Não estar/ficar em pé - no momento de passar a porta de entrada do pronto-socorro ou, depois, no momento da espera - constitui um elemento de imediata visibilidade que tende a ser apreciado pelos médicos como um sinal de extrema gravidade e, por conseqüência, de emergência. Aliás, a atenção suscitada, de imediato, pelo paciente que apresenta essa característica pode baixar muito depois, quando a primeira avaliação clínica indicar que seu estado de saúde não é nem tão sério, nem tão urgente assim. Nesse caso, o paciente não volta para a sala de espera, mas continua aguardando dentro da área de atendimento.

Essa aparente equivalência - a pessoa (consciente ou não) não está de pé (não anda) = seu caso é possivelmente grave - não existe só para os profissionais da saúde. O sinal 'estar deitado' chama atenção e alerta os profissionais não médicos do prontosocorro, os atendentes das centrais de chamadas, os motoristas de veículos de socorro, os transeuntes. Basta considerar, por exemplo, o grande número de chamadas recebidas pela Central de Ambulâncias que diz respeito a "uma pessoa deitada na rua". Geralmente, os solicitantes desconhecem a pessoa e nem se aproximaram dela antes de telefonar. ${ }^{9}$ Mas o simples fato de ela estar no chão os preocupa a ponto de eles ligarem para o 192 ou o 193. Em relação ao sinal 'estar deitado/não andar', profissionais da saúde e leigos compartilham a mesma apreciação inquieta: para todos, é um sinal de gravidade.

\section{Andar, Ficar em Pí, Falar}

Para os profissionais da saúde que atuam no pronto-socorro, não só vale a equivalência anterior, mas também o seu contrário. A espera a qual estão submetidos os pacientes que chegam e ficam em pé, e os percursos por eles seguidos, revelam a existência da equivalência oposta, a saber: a pessoa fica em pé (anda) $=$ seu caso certamente não está sério (grave). No pronto-socorro, 'andar' e 'falar' são sinais que não favorecem um atendimento rápido e que são lidos como indícios de um estado/ situação de saúde que 'pode esperar'.

Os pacientes que apresentam essas características ${ }^{10}$ são encaminhados primeiro para a recepção, pelo segurança da entrada; depois, para a sala de espera, pela recepcionista que preencheu sua ficha. O que significa que os profissionais com quem os pacientes estabelecem os primeiros contatos - até conseguirem a consulta médicasão dois tipos de agentes sem nenhuma formação médica: eles apreciam o estado de saúde como 'podendo esperar'; são os primeiros a lerem os sinais - 'está andando', 'está falando' - como indícios de um estado não preocupante.

Se os médicos do pronto-socorro não compartilhassem da mesma leitura, é de se duvidar que deixariam a primeira avaliação dos pacientes que andam e falam na mão de não especialistas que julgam por meio de um olhar superficial e rápido ${ }^{11}$ e de algumas perguntas. Se não fosse o caso, há de se pensar que, pelo menos no momento da primeira triagem (por exemplo, no momento do preenchimento da ficha), encontraria-se 
um profissional mais capacitado, do ponto de vista médico, para avaliar se o paciente pode ou não aguardar a consulta, e também para determinar, em termos de espera, a ordem das prioridades entre os pacientes que andam e falam.

Um efeito problemático da segunda equivalência é que ela desemboca no descaso da maioria dos pacientes e, especialmente, dos que são chamados 'casos clínicos'. De maneira geral, eles não chamam a atenção e constata-se que seu valor mobilizador é baixo. Contudo, da mesma maneira que nem toda pessoa desmaiada ou deitada está em um estado necessariamente preocupante, nem toda pessoa que fica em pé está necessariamente em um estado bom ou, pelo menos, razoável. A diferença, entretanto, é que, no primeiro caso, os pacientes se beneficiam de uma suspeita de gravidade que se traduz por uma primeira avaliação clínica que visa justamente a conferir a seriedade (urgência) do estado e a necessidade ou não de um diagnóstico mais apurado; enquanto, no segundo caso, os pacientes, por não se beneficiarem dessa suspeita, aguardam, até por muito tempo, o momento de serem examinados por um especialista médico e de serem medicados.

Ora, durante a espera, o problema/estado de saúde do paciente pode piorar a ponto de virar uma urgência/emergência. E se não sofre conseqüências tão dramáticas, com freqüência vivencia um sofrimento e uma angústia provocados ou aumentados pela própria demora do atendimento. Nesse caso, a situação de espera não coloca em risco sua vida, mas não deixa de levantar a questão de saber até que ponto se pode, eticamente falando, infligir esse sofrimento (físico e moral) aos pacientes que ficam em pé. E não somente a eles, mas também a quem os acompanha. Penso, particularmente aí, nas mães e pais que, já bastante preocupados no momento da chegada no prontosocorro, ficam esperando, agoniados, um atendimento para sua criança pequena. Vi acompanhantes de crianças como também de adultos e idosos tão angustiados pela espera que, não agüentando mais, ${ }^{12}$ acabavam deixando o pronto-socorro do Hospital das Clínicas com o doente para ir à procura de um atendimento em outro lugar.

O emprego do verbo 'infligir' não é fortuito. Observei freqüentemente que a espera dos pacientes 'de pé' não se explicava pela atividade dos profissionais de saúde, ocupados com casos que seriam mais urgentes e, por isso, prioritários. Muitas vezes, as salas de espera estavam cheias, enquanto vários médicos, residentes e enfermeiras se encontravam desocupados nas áreas de atendimento, e especialmente na sala de conforto, destinada ao descanso desses profissionais. De uma maneira geral, o contraste era forte entre as salas de espera, lotadas, movimentadas e barulhentas, e as calmas áreas de atendimento atravessadas, com tranqüilidade, pelo branco das blusas e calças. Era um pouco a paz versus o tumulto.

Entre numerosos exemplos de falta de consideração pelos casos clínicos e de seus efeitos negativos nos pacientes e acompanhantes (em termos de espera, risco e sofrimento), há o caso de uma mulher jovem (uns 20 anos) que fomos buscar de ambulância, uma manhã, na favela Argolo Ferrão, de Marília. Segundo o atendente da Central do 192, que se comunicou por rádio com o motorista, tratava-se "de um menino com febre". "O que foi passado para nós é isso", acrescentou ele, e, com essa informação, fomos à favela. 
Chegando lá, o motorista teve de parar, pois a rua estava com buracos tão grandes que não dava para ir até a casa da solicitante. Foi ela quem veio a pé até a ambulância, com seu neném nos braços, enrolado em um pano. Quando chegou na altura da ambulância, deu para ver que estava chorando e muito nervosa. Uma mulher trabalhando em uma lanchonete ao lado, comentou conosco: "o neném está virando os olhos". A mãe repetiu a mesma coisa, e subiu atrás da ambulância com a criança. No momento de dar a partida, o motorista comentou para mim: "Do que ela disse, parece que convulsou a filha dela".

Estávamos andando na estrada quando gritou a mulher atrás pedindo para o motorista parar porque a criança "tinha virado os olhos de novo". Ele parou imediatamente para ver o neném e tranqüilizar a mãe, muito assustada, e voltou para a frente da ambulância falando: "é nesses momentos que faz falta uma ambulância boa". Deu a partida, mas, dessa vez, aumentou bastante a velocidade. Essa aceleração associada ao uso repentino da sirena denotavam que, para ele, o caso da criança tinha virado urgente. ${ }^{13}$ Aliás, ele também abriu a janelinha da separação existindo entre a parte traseira e dianteira da ambulância, para poder jogar uma olhada atrás, de vez em quando, "para ver se está tudo bem". Comentou comigo que "não dá para estar ao mesmo tempo no volante e atrás", e também me informou que "no caso de uma convulsão, não tem nada para fazer"; é "só dar uma inalação para evitar a asfixia".

Uma vez no pronto-socorro, o motorista ajudou a mulher com o neném a descer da ambulância. Foi com ela até a recepção, deixou-a na fila pedindo-lhe para "esperar um pouquinho" que ele já estava de volta, e foi direto para a área de atendimento do pronto-socorro infantil à procura de um médico que pudesse examinar logo a criança. $\mathrm{O}$ comportamento do motorista indicava o quanto achava sério o caso do neném: ele ia tentar acelerar seu atendimento chamando a atenção de um médico. Ao primeiro que encontrou pediu com bastante precaução (isto é, sem parecer estar lhe ditando o que devia fazer) para sair na sala de espera para ver um nenê que "parece estar com convulsão". Este respondeu de maneira firme que não era pediatra. O motorista insistiu, mas o médico também, repetindo sua primeira resposta: não era pediatra e, então, esse caso não era dele.

Um outro médico passava no corredor, e o motorista o parou e voltou a expressar o mesmo pedido. Este respondeu que estava saindo, pois era sua hora de almoço. $\mathrm{O}$ motorista insistiu, e o médico repetiu que era sua hora de almoço. Mais firme do que a primeira vez, o motorista continuou persistindo, dizendo que era só ele dar uma olhada na criança. Aí o médico perguntou, num tom mais afirmativo do que interrogativo, "aconteceu ontem?", e o motorista respondeu que não, que a mãe tinha dito que tinha começado de manhã. Ao final dessa conversa tensa, o motorista obteve a saída na sala de espera do médico, que, pressionado, manifestava descontentamento e pressa.

Uma vez lá, na fila onde se encontrava a mulher, que continuava chorando, o médico jogou um olhar breve na criança (enrolada no pano e com os olhos abertos) e fez, em seguida, várias perguntas curtas para a mãe, mas sem lhe dar o tempo de responder: "desde quando?", "foi hoje?", "foi ontem?", "desde quando?", mas sem lhe dar o tempo de responder, acabando ele mesmo respondendo por um: "foi ontem", afirmativo. Sua única preocupação parecia ser a de saber quando tinha acontecido o problema, 
e a impressão que dava era que queria absolutamente que tivesse ocorrido 'ontem'. No momento, eu não compreendia por que insistia tanto em impor esse 'ontem'. ${ }^{4}$ Também não entendia por que não se interessava pelo problema da criança, não a olhava e nem a tocava para, pelo menos, mexer com o pano que a recobria toda. Mas o que percebia é que o médico ignorava o neném e queria que seu problema fosse do dia anterior.

Quando conseguiu um espaço para falar, a mãe disse que não tinha acontecido ontem, mas "essa manhã". Em resposta, o médico voltou a lhe fazer exatamente as mesmas perguntas como se, ficando surdo, não tivesse escutado nada e concluiu de novo: "foi ontem". A mãe repetiu que não, que o problema tinha acontecido de manhã e, dessa vez, acrescentou: "ela vomitou, saiu alguma coisa pela boca e os olhos viraram, e recomeçou agora". Neste momento, o médico olhou para o motorista e falou que não era convulsão: "a mãe se assusta porque não sabe"; este foi o último comentário que fez antes de ir embora e desaparecer na área de atendimento infantil.

Como não era conveniente insistir mais - dentro de uma relação altamente hierarquizada na qual o interlocutor era médico enquanto ele era apenas um simples chofer de ambulâncias -, o motorista renunciou. Tocou o ombro da mulher de maneira amigável e disse para ela continuar na fila, que iria ser atendida. Fomos embora, deixando-a calada, esperando sua vez, e atravessamos, silenciosos, a sala de espera do pronto-socorro: eu, atormentada por causa da cena que tinha acabado de presenciar e com sensação de muita impotência. Uma vez na ambulância, o motorista, revoltado, falou para mim: "ele disse que a mãe está assustada porque não conhece, mas como que ele sabe se nem examinou? Ele nem olhou para o nenê! Se fosse sua filha, acha que ele teria toda essa tranqüilidade?". E acrescentou um pouco depois: "se eu insistir demais, eles vão se queixar para a Central que eu invado seu campo".

Um certo descaso pelos casos clínicos pode ser observado também na ausência freqüente de um médico nas salas de triagem clínica infantil e, sobretudo, adulta, do pronto-socorro. Nesses lugares é atendida a maioria dos pacientes classificados como 'caso clínico' e considerados como 'podendo esperar' pelos seguranças, porteiros e recepcionistas. $\mathrm{Na}$ sala de triagem, eles passam por um primeiro exame feito por um médico, destinado a investigar e identificar seu problema. É por essa consulta que espera a maioria das pessoas, e é a partir dela que se vai desenhar, para cada um, o próximo trecho do percurso a seguir.

Certos pacientes, cujo caso é resolvido no momento da consulta, são mandados de volta para a casa com uma receita na mão. Outros continuam esperando porque o médico pediu exames a serem feitos no próprio Hospital das Clínicas: no que diz respeito por exemplo, ao raio-X, o paciente desce ao andar inferior onde aguarda sua vez. Outros ainda voltam à sala de espera onde ficam aguardando uma consulta na área de atendimento.

Destinada a desafogar o pronto-socorro, a triagem clínica tem também a função declarada de avaliar o nível de gravidade dos problemas apresentados pelos pacientes, no intuito de determinar o grau de urgência, mais ou menos grande, ou até nulo, do atendimento a lhes ser dado, isto é, sua inscrição na ordem das prioridades. Ora, muitas vezes, as salas de triagem estão vazias e por muito tempo (de uma a várias horas). As fichas dos pacientes adultos vão se acumulando na caixa que se encontra do lado da 
porta da sala de triagem adulto, depositadas no decorrer do tempo pelas recepcionistas. De vez em quando, o médico que atua na triagem sai da área de atendimento adulto para pegar o pacote de fichas, volta para a área de atendimento onde desaparece durante um tempo, geralmente longo, reaparece na sala de espera, mas não entra na sala de triagem, desaparece de novo, até o momento que começa atuar na triagem chamando vários pacientes em seguida. Depois de algum tempo, sai novamente, volta para a área de atendimento onde desaparece por um bom tempo e assim por diante.

A ausência de um médico atuando de maneira permanente na triagem testemunha o valor mobilizador muito baixo dos pacientes a serem examinados por ele. Dessa situação, só se pode deduzir que nenhum dos ditos 'casos clínicos' está a priori considerado como possivelmente urgente. O que leva a concluir, por fim, que "quem pode esperar" na apreciação primeira dos seguranças, dos porteiros e na avaliação das recepcionistas que preenchem as fichas sumárias transmitidas ao médico da triagem, também 'pode esperar' para os médicos. Pode esperar e, muitas vezes, espera mesmo: geralmente até receber um atendimento, às vezes até desistir e, em alguns casos, até morrer.

\section{Estar com um Problema Repentivo}

De maneira geral, constata-se também que é dada mais atenção ao paciente quando seu problema acabou de surgir. As perguntas "desde quando está com essa dor?", "desde quando está assim?", são entre as primeiras feitas aos pacientes pelas recepcionistas, no momento de preencher a ficha; pelos médicos e enfermeiros, quando atendem, e pelo pessoal das centrais de urgência/emergência, no telefone. Quando a pessoa responde "desde ontem à noite, há uma semana, um mês", muitas vezes, escuta o seguinte comentário: "mas por que não veio consultar antes?". E só por ter respondido que seu problema não é de agora, sai da categoria das possiveis urgências/emergências.

Dodier e Camus (1997a: 113) chegam à mesma constatação no que diz respeito à França quando fazem observar que mais os usuários do pronto-socorro argumentam com as recepcionistas que sua dor existe desde tempo, "menos chance têm de serem atendidos". 15

A questão do tempo não é, então, nada acessória: pois mais um paciente sofre de um problema antigo, mais será considerado como apto a esperar, conforme o seguinte raciocínio: já que o paciente esperou até agora, pode esperar um pouco mais. E mais: já que o problema esperou até agora, não é urgente (pois se fosse já estaria morto), então, não tem urgência em tratá-lo. Este raciocínio talvez seja esquisito para um observador exterior, na medida em que, segundo o raciocínio exatamente oposto, também se poderia considerar que o problema do paciente acabou se tornando urgente justamente por ele ter deixado passar tempo demais até consultar no pronto-socorro. Da mesma maneira, se poderia pensar que um sintoma (por exemplo, uma dor, que representa um caso bastante comum) que 'desde ontem', 'uma semana', 'um mês' não desapareceu, é o sinal possível de um problema sério que poderia ser encarado como tal, pelo menos de imediato, pelos profissionais da saúde que atuam no pronto-socorro. Mas para os médicos como, aliás, para as recepcionistas e os atendentes das centrais, é o primeiro raciocínio que prevalece. 
No que diz respeito às representações da urgência/emergência por parte dos médicos, esse dado vem, então, afinar as considerações anteriores: mais o problema (o sintoma) do paciente é novo, mais tende a ser considerado como o sinal de um mal possivelmente urgente. Aliás, 'novo' não é bem a palavra adequada. Para ser considerado como urgente e ser examinado com rapidez, o problema deve ter acabado de acontecer ou de se manifestar. Em outros termos: o que tende a ser considerado como possivelmente urgente é o que acabou de emergir. A partir daí, não é de estranhar que todo problema de saúde que apresenta um caráter crônico caia a priori fora do urgente, como ilustra de maneira exemplar esse comentário de um residente do pronto-socorro: "um toque [de campainha], não é uma urgência. Pode ser até um problema crônico, mas, enfim, mesmo assim precisa de uma maca".

Essa representação do que é urgente explica um outro fato importante, que será desenvolvido a seguir, a saber: a supervalorização, por parte dos profissionais da saúde do pronto-socorro, dos estados traumáticos como urgências e, sobretudo, como emergências. A superestimação dos estados traumáticos em relação aos casos clínicos encontra sua raiz na interpretação muito literal, ${ }^{16}$ do que é uma emergência, isto é, alguma coisa que acabou de surgir, de acontecer. O problema de saúde que apresenta essa característica tende a ser, a priori, considerado e tratado como uma emergência, o que é o caso, por excelência, dos estados traumáticos decorrentes de acidentes ou de choques que acabaram de ocorrer.

A desconsideração pelos problemas/sintomas antigos é notável nas numerosas histórias de pacientes 'chatos' contadas por médicos e residentes de medicina. Seu conteúdo é variável, mas, no fundo, quase sempre relatam a mesma história: a de pessoas que vieram consultar no pronto-socorro em um momento considerado inoportuno para um problema que não era novo, pois, como os próprios contadores se perguntam: "por que procurar o pronto-socorro agora?" - isto é, segundo as histórias narradas, no meio da noite, na noite do ano novo, na véspera do natal, perturbando o sono ou as comemorações dos que estão de plantão - "para um problema que, por ter esperado até esse momento, podia esperar ainda mais?".

Nos relatos, até parece que esses pacientes se dirigem ao pronto-socorro no meio da noite só para incomodar. Ilustração exemplar dessas histórias é a contada por um médico atuando na triagem clínica infantil. Ela diz respeito a um pai que levou sua filha para o pronto-socorro "na noite do Reveillon, às 23:54", no momento em que todos os médicos e residentes de plantão tinham acabado de se reunir para festejar a passagem do ano. "A menina estava com dor de ouvido desde três dias e é nessa hora, na meia-noite da passagem do ano, que traz ela!", exclamou. Contou ter perguntado para o homem porque vinha naquele momento, já que a menina estava com dor há três dias, ao que ele respondeu: "porque a minha filha está com dor". Acrescentou também que quando deu a receita médica para o pai, este perguntou: "onde que vou encontrar uma farmácia aberta nesta hora?", e resolveu ir buscar os remédios na manhã seguinte. "Então, por que vir nesse momento, encher o saco da gente, se é para comprar os remédios no dia seguinte?", concluiu o médico, indignado, com uma lógica implacável.

As histórias contadas para ilustrar as 'verdadeiras emergências' são bem diferentes: dizem sempre respeito a acidentes de carro, de avião, de trem e, para a chegada das vítimas 
neles envolvidas não há momentos inoportunos, nem no meio da noite. Ao contrário, o fato de elas chegarem no meio da noite parece aumentar ainda o caráter espetacular dessas emergências e a satisfação de quem estava de plantão para atendê-las.

\section{EstaR Com DoR}

Uma relativa indiferença à dor pode ser observada por parte do conjunto do pessoal médico e não médico que atua no pronto-socorro. Uma exceção deve ser feita em relação aos seguranças, que, muitas vezes, vi entrar na área de atendimento no intuito de chamar a atenção de um médico para um paciente que estava se queixando de sofrer muito ou manifestando muita dor. Importa dizer que se tratava, quase sempre, de pacientes mulheres. Os seguranças se mostravam bastante sensibilizados pelo sofrimento e lágrimas das mulheres na sala de espera, para as quais, muitas vezes, tentavam apressar a consulta, às vezes com sucesso. Um deles também sempre se mobilizava para tentar obter dos médicos o atendimento rápido dos pacientes com cólicas renais, independente do sexo. Por ter experimentado, justificava-se, dizendo que a dor é terrível: "uma dor que não dá para agüentar".

Exceção feita ao caso um pouco especial dos seguranças, ${ }^{17}$ constatei, de maneira geral, que o sofrimento físico não tem incidência sobre o tempo de espera para um atendimento. A dor não é lida pelos médicos como um sinal de urgência ou de emergência, qualquer que seja o comportamento do paciente: quer manifeste sua dor (gemendo, contorcendo-se, gritando, chorando), quer fique quieto.

Do ponto de vista do discurso, as falas desses profissionais deixariam até pensar que ficam mais preocupados com um paciente que não expressa nada - esse que "fica calado em seu canto" - do que com os que expressam, de maneira visível e sonora, seu sofrimento. Pois, segundo eles, um paciente "barulhento" mostra, pela própria extroversão de seu sofrimento, que não está tão mal assim: se ficasse ruim mesmo, não teria tanta energia. Visto sob esse ângulo, gemer, gritar, queixar-se, protestar, são interpretados como sinais de saúde ou, melhor, de vida. Mas, como de um outro lado, a observação revela que ficar quieto também não aumenta o valor mobilizador do paciente, mas até tende a diminuir suas chances de conseguir mais atenção no decorrer da espera, ${ }^{18}$ manifestar a dor ou ficar quieto dá no mesmo.

Para muitos médicos e enfermeiros, o sofrimento tanto físico quanto moral - sua vivência e expressão - diz respeito à esfera psicológica e, por isso, é desacreditado ("é psicológico"), objeto de desconfiança ("o paciente finge") e de desprezo ("quem grita, está ótimo"). Uma ilustração dessa constatação pode ser encontrada na conversa, bastante esclarecedora, de um médico aconselhando um porteiro do pronto-socorro cuja função é, entre outras, barrar a entrada indesejada de pacientes ou de acompanhantes na área de atendimento. O médico explicou para ele que devia ser simpático com os pacientes que esperam, pois "quem vem aqui, a maioria não é urgência", "não tem nada", " $50 \%$ é psicológico". O porteiro tinha de se mostrar simpático, sobretudo, com "a pessoa que se queixa de dor forte", pois, se ficar "brusco com ela, vai se sentir pior e se queixar de uma dor maior", enquanto "se conversar com ela, a dor passa e ela vai embora tranqüilamente". Como prova, apontou para uma moça que estava chegan- 
do no pronto-socorro, muito agitada, gritando e tremendo, e falou: "você vê o que estou dizendo, é psicológico".

A colocação anterior pode ser, aliás, estendida a todos os sintomas e problemas que apresentam uma dimensão psicológica explícita, ${ }^{19} \mathrm{e}$ mais ainda quando se manifestam em mulheres, aparentemente tidas, por numerosos médicos, como grandes atrizes. As risadas, brincadeiras e comentários cúmplices (muitas vezes de conotação sexual) trocados entre médicos (e residentes) a propósito das mulheres que chegam em estado de grande agitação testemunham seu descaso, e até seu desprezo, por essas pacientes exageradas que "não têm nada físico".

Bastante significativas são as várias denominações que lhes são dadas, tais como "peripaque", "piti", "SVC" (Síndrome da Vagina Carente), "SPA" (Síndrome do Pênis Ausente). O problema dessas mulheres "é a cabeça", e, por isso, não é levado a sério em termos de gravidade e de urgência, pois o corpo não está explicitarnente comprometido, nem as "funções vitais".

Entre as dores, uma é figura de exceção, pois é geralmente levada muito a sério pelos médicos, sobretudo se é recente: a 'dor no peito'. Ela confere ao paciente um valor mobilizador alto que se traduz por um atendimento rápido, pois pode ser o sinal de um enfarte que, entre os ditos 'casos clínicos', é considerado como a emergência por excelência. Nos exemplos de emergências que dão os médicos, o enfarte é o único problema de saúde não decorrente de um trauma físico, sistematicamente citado ao lado dos acidentes. Assim, é considerado também pelos seguranças e atendentes de centrais. Segundo bombeiros que atuam na central do 193, o enfarte é o único 'caso clínico' que resgatam sistematicamente, como o fazem com os problemas resultantes de acidentes, pois, como estes, é uma emergência.

Certos pacientes sabem do valor dado à 'dor no peito' e a assinalam quando querem a vinda do Resgate ou de uma ambulância. É comum os solicitantes se referirem a esse sintoma no telefone, e os motoristas do 192 descobrirem, uma vez no lugar, que a pessoa a ser atendida nunca sentiu essa dor, mas está sofrendo de outra coisa, por exemplo, de coma alcoólico, para o qual se teme não conseguir a assistência da ajuda movel de urgência. A mesma observação pode ser feita no pronto-socorro. A importância dada pela equipe médica à dor no peito é facilmente perceptível e certos pacientes se queixam desse sintoma no intuito de apressar o atendimento. A cena seguinte exemplifica a atenção explícita dada a essa dor pelos médicos.

Uma tarde, a médica responsável pela triagem clínica veio à sala de espera com um maço de fichas na mão. Chamou um paciente que não estava, e depois, em discurso aberto às pessoas que aguardavam, disse que o movimento estava sobrecarregado, assim sendo os "casos mais graves" deveriam ter a preferência. Posto isso, começou, a partir das fichas, a chamar um paciente de cada vez, fazendo-o levantar e em seguida sentar novamente. À primeira perguntou se sentia dores fortes, e esta prontamente respondeu que sim. A médica perguntou, então, se era possivel que esperasse mais um pouco. Em seguida, a mulher sentou-se com uma cara de pobre infeliz, e a médica continuou sua volta: "quem tiver alguma coisa mais grave..., você está com dor no peito ou na garganta?". Ao final de sua pesquisa, não tendo aparentemente encontrado 
ninguém que se encaixasse na categoria 'caso grave', perguntou a todos : "alguém está com dor no peito ou alguma coisa assim?".

Levantou-se uma mulher, cerca de 40 anos, dizendo sentir dor no peito. A médica pôs-se a perguntar-lhe por que, então, ela não tinha posto tal sintoma na sua ficha. Como a atitude e a resposta da mulher não eram muito convincentes, a médica, achando que ela tinha mentido, mandou um enfermeiro, que passava por lá, avisar "um médico" sobre suas dores no peito e voltou para a sala de triagem, onde se fechou.

$O$ resultado da interação foi, então, que a mulher continuou aguardando o atendimento, mas, dessa vez, muito descontente: "coisa de governo é coisa de governo. Eu vou chamar o Ratinho. Ele mete a boca no trombone. Pelo menos melhora para outras pessoas. Nem que seja a última coisa que eu faça na minha vida!", comentou para todos. Ela tinha sido encaminhada de Adamantina para que fosse realizado um enxerto em sua perna, pois tinha sido mordida por um cachorro.

\section{Estar com Trauma Físico}

Os estados de saúde que têm e, de longe, o maior valor mobilizador são os estados traumáticos (ou possivelmente traumáticos) que apresentam sinais visíveis e impressionantes, tais como sangue, perda de consciência, feridas e fraturas visiveis. Resultam de acidentes diversos, tais como os de trânsito, atropelamentos, quedas, acidentes do trabalho, entre os mais comuns.

Em vítimas de acidentes, suspeita-se a existência de possíveis traumas, isto é, de problemas causados de maneira súbita por um agente físico e especialmente por um choque violento. Para os médicos, importa identificar e avaliar rapidamente do que sofrem. Por isso, essas vítimas são atendidas com pressa à medida que apresentam um ou vários dos sinais visíveis anteriormente citados, e, sobretudo, a perda de consciência. De maneira geral, as vitimas de acidentes tendem a ser a priori consideradas e tratadas como possíveis urgências ou emergências. Elas se beneficiam de uma suspeita de gravidade que não suscitam os outros pacientes, especialmente, os ditos 'casos clínicos' (com as exceções já assinaladas), pois se estes são considerados como possivelmente não graves, os primeiros são encarados como provavelmente sérios e urgentes.

Chega-se, então, à seguinte compreensão: entre os problemas de saúde, os que têm maior poder mobilizador, os mais valorizados como urgências/emergências, são os decorrentes de choques físicos repentinos. E, entre eles, ainda existe uma escala entre os mais e menos mobilizadores. Os mais valorizados são os que ocorrem em conseqüência de acidentes com suspeita de politraumatismo, como é o caso dos acidentes que acontecem na estrada ou que envolvem veículos de transporte. Emergências por excelência, esses estados (possivelmente) traumáticos também chamados pelos médicos de "emergências cirúrgicas", são, de longe, os mais espetaculares. Sâo eles que os profissionais de saúde sempre citam quando querem definir ou ilustrar o que é uma emergência, tal como esse residente de medicina que relatou bastante animado: "ontem à noite você perdeu uma urgência, uma verdadeira essa, uma emergência! O piloto de um avião que caiu $\mathrm{cm}$ uma casa de Marília!'. São esses casos que os médicos, que afirmam gostar de trabalhar na urgência/emergência, também dizem preferir atender. São eles que "fa- 
zem subir a adrenalina" ${ }^{20} \mathrm{e}$ cuja chegada ao pronto-socorro é assinala pelo segurança à equipe médica por dois toques de campainha.

A maioria das vezes, esses casos são levados pelos bombeiros, o que também tem um impacto na mobilização e na rapidez do atendimento, pois casos semelhantes que chegam por meios próprios (de carro particular, de ônibus) não são atendidos com tanta rapidez. Deu para observar vários casos, de homens, sobretudo, vindo se consultar por meios próprios por causa de acidentes ${ }^{21}$ que, depois de terem passado em pé pela porta do pronto-socorro, sem sinais aparentes ou sem sinais aparentes impressionantes, ${ }^{22}$ foram preencher sua ficha. Eles esperaram, às vezes, por muito tempo, sem ver um médico até serem atendidos, sem receber um exame clínico nem superficial na chegada, isto é, sem que fosse avaliada a gravidade das lesões das quais podiam estar padecendo, mesmo que conscientes (por exemplo, hemorragia interna, lesão arterial parcial etc.). Em comparação, pacientes conscientes, vítimas de acidentes, que chegavam na viatura do Resgate, eram levadas diretamente para a área de atendimento.

Além da questão do transporte, tem-se que ver também que os primeiros pacientes passavam pela porta do pronto-socorro andando e conscientes, enquanto que os segundos, mesmo que conscientes, entravam geralmente deitados em maca, o que nos remete ao que já fora dito sobre a incidência desta situação no atendimento: quem passa em pé pela porta do pronto-socorro, e não só os acidentados, aguarda mais (e bem mais) o primeiro atendimento do que quem entra deitado, desmaiado ou não, em um estado apreciado pelos bombeiros ou pelos motoristas de ambulância como grave ou não.

Ilustração da mobilização menor suscitada pelos pacientes que, vítimas de acidentes, não chegam de bombeiros, entram andando e não apresentam os sinais visíveis e impressionantes anteriormente citados, é o caso de uma família de aparência muito humilde que o motorista de um carro particular deixou, num final de tarde, na porta do pronto-socorro meio vazio.

O pai e a mãe entraram com os dois filhos pequenos, uma menina de uns 2 anos e um menino de uns 7 anos. A criança maior mancava e segurava, chorando e gemendo, seu braço aparentemente quebrado. $O$ pai pediu para a recepcionista o atendimento imediato da criança. Em resposta, ela pediu para ele preencher a ficha e esperar. Ele insistiu, dizendo que seu filho estava com o braço quebrado e com muita dor, mas foi sem sucesso, e a família toda foi sentar-se à sala de espera do pronto-socorro infantil, vazia. O menino continuava segurando seu braço, chorando e gemendo baixinho, enquanto a mãe, silenciosa, manifestava sinais de preocupação extrema.

Depois de algum tempo, o pai levantou e foi para a recepção onde voltou a pedir um pronto-atendimento e recebeu a mesma resposta: tinha de esperar sua vez. Voltou a sentar-se, visivelmente descontente. Durante esse tempo todo, nenhum médico (ou residente) saindo da área de atendimento infantil ou adulta parou para dar uma olhada na criança (também não tinha nenhum médico atuando na sala de triagem clínica infantil).

Ao fim, cerca de quinze minutos depois, o pai levantou-se novamente, dessa vez com a família toda, e eles se encaminharam para a saída do pronto-socorro. Quando passaram na frente das recepcionistas, houve uma breve troca de palavras que não escutei, e continuaram atravessando a sala de espera adulta em silêncio, o menino ainda chorando baixinho e segurando seu braço. Passando a porta do pronto-socorro, a mãe 
disse para o segurança que ficou quieto: "não tem médico. É possível uma coisa dessa?". E foram embora, descendo a pé a rampa de acesso ao pronto-socorro.

Vendo isso, fui falar imediatamente com as recepcionistas para saber o que tinha acabado de acontecer com essa família. A mulher que cuidou do caso, ainda nervosa, falou com bastante irritação que "não quiseram esperar", criticou em seguida a atitude errada deles, ressaltando a impaciência e a falta de compreensão de que "não tem só eles". "O ortopedista ${ }^{23}$ está ocupado. É sempre assim: chegam e já querem ser atendidos!", concluiu a recepcionista, generalizando seu comentário a todos os pacientes que procuram o pronto-socorro. ${ }^{24}$

Afinal, se as vitimas de acidentes (e, especialmente, de acidentes acontecidos na estrada, envolvendo ou não meios de transporte) aparecem tidas como as emergências por excelência, é porque muitas vezes juntam todos os grandes sinais que têm um alto poder mobilizador dentro das representações da urgência/ emergência: estar desmaiado; estar deitado (consciente ou não); chegar na viatura do Resgate; estar com um problema que acabou de surgir e que engaja explicitamente o físico por decorrer de choques com coisas materiais. A essas características, há de acrescentar outra importante: a presença de sinais visiveis e impressionantes no paciente, tais como sangue, feridas e fraturas expostas etc. E não só isso: o caráter também muito visível e impressionante da situação que deu origem aos (possíveis) problemas dos pacientes, isto é, o próprio acidente, cujo aspecto espetacular parece aumentar ainda o caráter possivelmente emergente do estado de saúde de quem está envolvido nele. Nos exemplos de emergências que me davam, certos médicos comentavam com ênfase o próprio acidente, apesar de não o terem visto, pois não vão buscar as vítimas.

Parece, então, que as urgências e, mais ainda, as emergências são representadas e identificadas, na base das características gerais apresentadas pelos problemas de saúde que decorrem de choques físicos e pelo tipo de situação que provocam os acidentes. É como se, na prática, existisse e se concretizasse a seguinte equivalência: emergência = casos traumáticos, isto é, casos que levam à suspeita da necessidade de uma intervenção cirúrgica rápida. A identificação da emergência com a necessidade de uma operação imediata fica bem resumida e explicitada em uma frase ouvida várias vezes da boca de profissionais da saúde: "é emergência porque vai para a cirurgia".

Ora, os estados de saúde da imensa maioria das pessoas que vão para o prontosocorro não apresentam os caracteres de uma emergência pensada a partir dos (possíveis) estados traumáticos oriundos de acidentes. Não sendo necessariamente menos graves do que os dos acidentados, seus problemas apresentam sinais geralmente mais discretos: suas manifestações físicas são menos visíveis e espetaculares; suas causas menos impressionantes e brutais. Por se afastarem dos sinais mobilizadores que fazem sentido dentro das representações biomédicas da urgência/emergência, esses casos não são valorizados como urgentes ou emergentes; tendem a se fundir na vasta categoria dos problemas que 'podem esperar': categoria ampla em que, afinal, revela-se difícil presenciar e identificar, em contexto, aquilo que pode esperar menos daquilo que pode esperar mais. 


\section{Notas}

1 Precisa assinalar de antemão que essa familiaridade não é compartilhada por outros profissionais não médicos da rede de atendimento às urgências e emergências e, menos ainda, pelos usuários (pacientes e acompanhantes), que não só não se referem espontaneamente a essa distinção, mas também não estão acostumados com a utilização do termo 'emergência(s)'.

2 Quando existe, pois o diagnóstico, no pronto-socorro, muitas vezes com base, segundo o dr. 2, nos resultados obtidos a partir dos instrumentos da tecnologia médica (raio-X, ultra-som etc.) e não sobre o exame clínico, inexistente.

3 Expressão de uma construção que não informa sobre o que acontece, de fato, no nível das práticas, isto é, em situação.

4 Ver Capítulo 3.

5 O que é geralmente o caso, quando chegam de bombeiros.

6 A mesma observação pode ser feita em relação aos pacientes que entram sentados no pronto-socorro, em uma cadeira de rodas que lhes dá o segurança da entrada. Mas ela é menos sistemática, pois, aí, são outros sinais levados em conta (como o estado aparente do paciente, o caso de um retorno ou não) que fazem com que os pacientes esperem ou sejam objetos de uma atenção imediata. Se, de uma maneira geral, entrarem sentados, tende a acelerar o processo que leva a um primeiro atendimento, entrar deitado garante mais sua rapidez.

7 Foi, por exemplo, o caso dramático de uma mulher com uns 55 anos, que estava esperando sua vez há muito tempo, sentada e quieta, na sala de espera. Quando começou a desmaiar, um segurança se precipitou para segurá-la e impedir sua queda no chão. Levada imediatamente para a área de atendimento médico, foi atendida na hora e morreu pouco tempo depois. Estava com edema pulmonar.

8 Como é o caso de todos os pacientes que esperam, durante muito tempo, sua vez de serem atendidos.

9 Os solicitantes geralmente alegam medo, e os atendentes da Central têm grande dificuldade em conseguir que eles se aproximem da pessoa a socorrer para lhes dar maiores informações sobre seu estado.

10 Exceção feita aos que se queixam - na entrada ou no momento de preencher sua ficha - de certos sintomas levados a sério por serem considerados sinais de uma possível emergência: entre os mais comuns, a "dor no peito", a "falta de ar" e as "dores do parto", para reproduzir aqui as expressões usadas pelos pacientes. Os que se queixam desses problemas geralmente não esperam tanto quanto os outros. Retomaremos mais detalhadamente essa questão.

11 Através da grade no caso das recepcionistas que preenchem as fichas.

12 A angústia está aqui ligada à impressão, por parte do acompanhante, que o paciente, já muito mal, está piorando, isto é, que vai acabar morrendo na espera. Também 
está relacionada ao sofrimento, não aliviado, do doente cujas manifestações acabam se tornando intoleráveis para quem o acompanha.

13 Em todo tempo que acompanhei os motoristas, raros foram os momentos em que usaram a sirene e andaram com velocidade.

14 Entendi melhor depois, quando, no decorrer do trabalho de campo, dei-me conta de que, dentro de suas representações da urgência e da emergência, os médicos tendem a dar mais importância a um problema (ou sintoma) quando acabou de acontecer ou de manifestar-se. Essa constatação será examinada a seguir.

15 Aos usuários que adiantam que seu caso é grave ("Morro de dor desde três semanas"), é respondido: "Mas justamente. Se você está sofrendo há três semanas é porque seu problema não é urgente!"'(Dodier \& Camus, 1997: 113, tradução livre).

16 Ver a definição do dicionário.

17 Sem formação médica e novos na função de segurança de hospital e de prontosocorro.

18 O que pode conseguir o paciente que manifesta seu sofrimento é ser atendido, às vezes, com mais rapidez, simplesmente para acabar com a perturbação ou a inquietação que ele cria na sala de espera.

19 Entre os quais os que remetem à categoria dos ditos 'casos psiquiátricos'.

20 Para retomar uma expressão muito ouvida, sobretudo por parte de residentes de medicina e enfermeiros.

2) Acidentes de moto, de carro, de trabalho; quedas de cavalo, na rua, no ônibus, de um lugar elevado.

22 Afora a roupa rasgada, manchas de sangue seco, o fato de mancar.

23 A separação das competências médicas em especialidades, dentro do pronto-socorro, revela-se problemática em termos de atendimento, pois geralmente os médicos só atendem os casos que dizem respeito à sua especialidade. Quem não é pediatra não olha criança (ver o caso do neném que 'virou os olhos'); quem não é ortopedista ignora os pacientes que estão com um problema classificado pelas recepcionistas como sendo da ortopedia etc. Chega-se assim a situações, como a descrita, em que médicos e residentes desocupados e disponíveis não atendem porque o caso não diz respeito à sua especialidade ou ao estágio por especialidade que estão fazendo no pronto-socorro. A pertinência de uma interpretação tão rígida da atuação por especialidades mereceria ser interrogada dentro de uma perspectiva de melhora no atendimento.

24 Esse episódio representou um dos momentos em que duvidei de conseguir a distância necessária à realização de um trabalho de campo no pronto-socorro. 


\section{5 \\ "Pode Esperar? Dá para Agüentar?": a perspectiva dos seguranças, porteiros e recepcionistas}

O pessoal não médico do pronto-socorro mobiliza representações das urgências e das emergências que parecem, em diversos pontos, com as dos profissionais da saúde. Apresentam, porém, diferenças que, como as semelhanças, merecem ser apontadas.

\section{Os Seguranças e Porteiros}

Antes de trabalharem no pronto-socorro, os seguranças, empregados de uma empresa privada, trabalhavam em bancos e organizações públicas. Alguns, aliás, continuavam com esse primeiro emprego em seus dias de folga do pronto-socorro. Antes, nunca tinham atuado na área da saúde, portanto, essa primeira experiência os colocava diante de situações inéditas. Esse dado tem de ser levado em consideração na leitura do que vem a seguir, pois se os seguranças estivessem ocupando essa função há algum tempo - como é o caso dos porteiros e das recepcionistas - há de se pensar que os dados de observação e de discurso recolhidos a seu respeito poderiam ter sido diferentes. Por exemplo, o fato de eles se mostrarem muito sensibilizados pelo que acontece no pronto-socorro, e especialmente com os pacientes, pode estar ligado, não só à sua identificação com pessoas que pertencem à mesma camada social que eles, mas também ao fato de que são novos no emprego.

Acostumados com o universo do pronto-socorro, as recepcionistas e os porteiros também apresentam o mesmo perfil sociológico dos pacientes, porém mostram-se indiferentes a muitas situações que tocam os seguranças. Quando comecei o trabalho de campo, estes estavam descobrindo uma realidade que, mesmo se não a desconhecessem por já terem ido como pacientes ou acompanhantes a um pronto-socorro, não conheciam a partir do lugar e da função de segurança.

\section{InCONFORMAdos E Críticos}

Ficando $12 \mathrm{~h}$ seguidas em pé,' na entrada ou na sala de espera, os guardas encontram-se como observadores de uma multidão de situações que os deixam muito críticos em relação ao que acontece no pronto-socorro e, especialmente, em relação ao 
comportamento dos médicos. Expressam sua indignação, no tom da confidência, contando-me espontaneamente as coisas que os revoltam. No início, alguns deles chegaram até a dizer que não iam ficar por muito tempo nesse emprego.

Eis alguns trechos de conversa representativos de seus comentários críticos e que testemunham sua sensibilidade à situação dos pacientes, até sua empatia:

O segurança é surdo e mudo. Mas se eu contar tudo que vejo aqui, teria bombas para muitos. Coisas erradas e coisas certas, você vai ver aqui, mas você vai ver sobretudo coisas erradas. Aqui é um absurdo. [E, depois de ter contado a história de um menino que, segundo ele, morreu no pronto-socorro, por falta de cuidados:] A pessoa fica quieta, não diz nada, os médicos não prestam atenção. [E, no tom da ameaça:] Se eu levar minha mulher ou meu filho e tratarem desse jeito! (...) O outro dia, minha mulher levou a menina da vizinha que tinha cortado o pé, desceram para o raio-X, esperaram uma meia hora lá em baixo, o médico estava assistindo $O$ Ratinho! (...) Eles [os médicos] atendem rápido só quem vem de ambulância ou de bombeiros. Os outros ficam sentados, que nem essa mulher que desmaiou. Se a cabeça dela bater nos ferros ou no chão, você imagina... Segurei a cabeça nas minhas mãos. Ela se queixava de dor, chorava, mas não ligaram para ela, até ela cair.

O segurança tem que ser mentiroso, cego, mudo e surdo. (..) É um trabalho dificil, você vê tantas coisas e não diz nada, nós vemos tudo que acontece aqui. Eles [os médicos] nem olham na saia de espera. [Conclui que é mais fácil e tranqüilo ser segurança de banco].

O médico diz que nós temos dó demais deles [os pacientes], que têm que ser rigidos, que não pode ter o coração mole. Dizem que os pacientes mentem, mas eu tenho dó, não sou assim. Se eu ver que uma pessoa está passando mal, eu coloco ela dentro [da área de atendimento]. Se o médico achar ruim, pego o nome dele e se tiver qualquer problema, digo que não quis atender. Felizmente essa situação nunca aconteceu.

Os médicos dizem para nós que os pacientes fingem, que a gente não deve se sensibilizar, talvez seja verdade para alguns deles, mas para a maioria está errado. Tenho dó. A gente olha para as pessoas e não pode fazer nada. É como essa menina que está chorando, o que quê ela tem? [Depois de alguns minutos, vai falar com ela e volta dizendo:]-É a garganta, muito vermelha, inchada. [E repete várias vezes:] - Deve sentir muita dor.

[Comentando a atitude de uma médica:] Que frieza, estudar tanto para isso! E não é porque a pessoa entra dentro [da área de atendimento] que eles [os médicos] cuidam dela, eles deixam ela num cantinho, numa maca, eles te deixam sem cuidados (...) Isso é nosso [o PS], isso é público. Mas mesmo assim somos bem mal tratados.

Entretanto, os seguranças não deixaram o emprego. Mas o discurso foi mudando. Menos revoltados e mais acomodados ao longo das semanas, continuaram achando que o que acontece no pronto-socorro "não está certo", mas mostravam mais distância e tranqüilidade: "aqui é bem pesado, mas já me acostumei"; "tenho dó, mas agora 
me acostumei". Até o mais inconformado no início, acabou achando seu trabalho "gostoso" e explicava: "me ajuda a tomar distância, agora vejo um caso grave, uma coisa absurda, eu dou risada. Esse trabalho é uma terapia".

Somente um deles, um dia, não apareceu mais no pronto-socorro e passou a trabalhar no portão de uma outra entrada do hospital. Foi transferido de lugar porque, segundo suas próprias palavras, os médicos e o chefe da segurança o achavam "demais emotivo". "Uma médica me disse que eu era demais sentimental", comentou ele, lamentando ter precisado deixar esse trabalho porque "gostava de ajudar" apesar de que "no pronto-socorro, muita gente tem o coração ruim, sobretudo os médicos". Alegou ter presenciado vários comportamentos "errados" por parte da equipe médica e, entre eles, relatou o caso de dois pacientes "que [os médicos] deixaram na espera" "um com hemorragia" e um outro "que desmaiou" - e que, sem autorização dos médi$\cos$, ele levou para a área de atendimento, iniciativas que certamente estavam na origem de sua saída do pronto-socorro: "desmaio, hemorragia, tem que entrar direto!" exclamou indignado, acrescentando que não estava com vontade de se tornar "insensível" e que "se tiver que perder o emprego vou perder, mas não vou mudar".

As críticas dos guardas mostram claramente que suas representações do urgente, suas apreciações do que "pode esperar" e do que necessita de um atendimento rápido, entram em conflito com o que o cotidiano do pronto-socorro revela das práticas dos profissionais em relação à urgência. Porém, a manifestação desse confronto por parte deles não passa, geralmente, de severos, mas discretos, julgamentos, e fica imperceptível ao observador exterior.

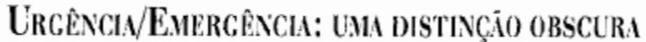

Talvez por serem novos no pronto-socorro, mas não necessariamente, os seguranças não têm nenhuma familiaridade com a discriminação entre urgência e emergência. Apesar de sua função os levarem a recorrer a essa distinção e terminologia com freqüência - "toco duas vezes na campainha no caso de uma emergência", "aqui é só urgência-emergência" - as diferenças entre as duas categorias de urgência como seu significado próprio não é nada claro para eles. Nisso, não diferem dos usuários.

$\mathrm{Se}$, de um lado, entendem que certas urgências são mais graves do que outras, do outro lado, não sabem muito bem às quais se aplicam os termos 'urgência' e 'emergência'. Às vezes, apresentam as urgências como sendo mais graves do que as emergências, mas também dizem o contrário; às vezes, as urgências e as emergências são tudo que chega no pronto-socorro, é tudo igual e 'urgência emergência' se torna uma palavra só. Às vezes, é o próprio meio de transporte que traz o paciente que determina se é urgência (ambulância) ou emergência (bombeiro), sem que o critério de gravidade seja levado em conta na distinção entre as duas, assim como mostram esses trechos de suas falas: "Um toque [de campainha] é quando é uma emergência não muito grave; dois toques é quando vem o Resgate, você já sabe"; "Campainha é urgência. 1 toque: menos grave. 2 toques: mais grave"; "Dois toques é quando é uma urgência, quando é grave"; "Dois toques é quando é urgência emergência"; "Emergência é bombeiro, dois toques; urgência são as ambulâncias, um toque"; "Se tivesse só urgência 
emergência aqui, não teria tantas pessoas"; "Urgência emergência, acho que é a mesma coisa. Que nem esse cara. Pode esperar"; "A emergência é todos que vêm aí...A urgência é quando está ruim, quando está nas últimas"; "Urgência tem que intervir rápido (...), emergência são essas pessoas [os pacientes esperando]"; "o que ela tem demora para curar, o tratamento é demorado, não é agora que ela vai melhorar, não é urgente" (Grifos meus).

Apesar de terem uma compreensão variável do que são uma urgência e uma emergência, os seguranças não deixam de ter uma apreciação do que é grave, quer eles chamem isso 'urgência', 'emergência' ou ainda 'urgência emergência'. E, apesar de não ser sua função declarada, eles observam os pacientes com atençăo, preocupados em presenciar os indícios de um possível caso grave.

\section{Observação atenta e Sentimento de Responsabulidade}

Entre todos os profissionais do pronto-socorro, os seguranças são os únicos, com os porteiros, que vêem o que acontece na sala de espera adulto. A pequena sala onde se encontram as recepcionistas não dá visão para as salas de espera (adulto, infantil), mas para uma parede e um relógio, ${ }^{2}$ e quando saem desse lugar para entregarem as fichas nas áreas de atendimento, elas atravessam rapidamente os espaços reservados ao público sem olhar para ele. No que diz respeito aos profissionais de saúde, já vimos que eles geralmente não vão para as salas de espera, e quando as atravessam é também de maneira apressada. "Os médicos passam correndo pela sala de espera", "os médicos nunca estão por lá”, observam os seguranças. Aliás, discursos de médicos confirmam o que a própria observação leva a pensar, a saber, que sua ausência nas salas de espera e a rapidez de sua passagem por elas são voluntárias. "Não fico fora, não vou na sala de espera", diz esse médico (responsável pela triagem clínica do pronto-socorro infantil) que explica os motivos de sua atitude da seguinte maneira:

Se olhasse para eles, se passasse no meio deles na sala de espera, daria para ver quem tem que ser atendido, mas não faço, não posso, nenhum dos médicos do pronto-socorro faz. Eu passo, dou uma olhada mas não mais, não olho para eles. Se eu olhar vão achar que estou dando risada, não dá para passar entre eles, eles văo achar que não faço nada. Eles vão me falar, não vou poder trabalhar mais.

Os únicos observadores da sala de espera do pronto-socorro adulto ${ }^{3}$ são, então, os seguranças e porteiros: é a eles que está abandonada essa tarefa que, aliás, levam muito a sério. Intriga constatar o quanto, apesar de não terem nenhurna formação médica e não estarem explicitamente encarregados da triagem médica dos pacientes, eles desempenham sua tarefa de observação não só com aplicação, mas também com o sentimento de serem responsáveis por tudo que acontece na sala de espera, inclusive pelo estado de saúde das pessoas que estão aguardando. Os seguranças e porteiros vivem a eventualidade temida de um paciente passar mal - desmaiar, por exemplo como uma coisa a ser absolutamente evitada. Interiorizaram que é de sua responsabilidade impedir esse tipo de situação, como se dependesse deles, de sua competência ou incompetência, acontecer ou não: "a gente tem que se proteger no caso de problemas, 
[diz esse guarda da entrada], pois tudo que acontece na sala de espera é problema nosso, é da nossa responsabilidade. É o que dizem os médicos para nós".

Não deu para saber com certeza se este sentimento é o resultado da incorporação pelos seguranças e porteiros de uma responsabilidade que os profissionais de saúde passam para eles, de maneira implícita ou explícita, ou se são eles mesmos que fazem uma interpretação exagerada de sua função de segurança, ou se é, ainda, uma mistura dos dois. Mas, com efeito, eles são encarregados de avisar um médico na área de atendimento quando presenciam que "uma pessoa está passando mal", e essa atribuição pode estar na origem de seu sentimento de responsabilidade. $O$ fato é que eles se consideram responsáveis pelos pacientes que aguardam, e mais do que os próprios profissionais de saúde que lhes deixam a tarefa de olhá-los atenciosamente para poder intervir a tempo, caso precisar. Daí a seriedade e a preocupação com as quais desempenham seu papel de vigia.

A contrapartida valorizante é o orgulho que os seguranças têm por sua habilidade em ver e perceber "as coisas". Contando-me uma história de ladrões que tinha reparado na rodoviária, um dos guardas declarou possuir um talento especial para "sentir essas coisas": "é como no PS, eu olho, olho, olho e vejo quando a pessoa não vai bem ou está passando mal". Aliás, os médicos já lhe disseram que "para isso, tenho nota 10 " e que ele é "muito bom para ver quem fica doente ou quem vai passar mal, para ver os pacientes que precisam: eu vejo quando a pessoa tem falta de ar e vai cair no chão", diz ele, exemplificando com o caso de uma mulher que tinha desmaiado alguns dias atrás na sala de espera (situação que também presenciei). Ele foi o primeiro, entre os seguranças e porteiros, a reparar que ela ia desmaiar e, por isso, precipitou-se para "pegar a cabeça da mulher" antes de ela cair, para "a cabeça não bater no chão". "Ela era muito gorda, então imagina com todo esse peso, a cabeça bater no chão, pode se matar", comentou ele.

Um dos porteiros do hospital, o mais antigo nessa função, procura se distinguir dos seguranças justamente por sua aptidão aguçada em reconhecer "quem está passando mal". Afirma sua competência na leitura dos sinais de gravidade, negando a dos guardas: "não sabem", "erram", "não servem para trabalhar, não têm preparo", diz a respeito deles. Sente-se muito importante, e até indispensável, por ter essa faculdade e declara com muito orgulho: "os médicos nunca vão me tirar do lugar". Aliás, ele sempre insistiu, em nossas conversas, em dizer o quanto os médicos o acham competente.

Cada segurança e porteiro, tendo interiorizado que o segurança ou o porteiro 'bom' é esse que 'sabe ver', pressentir, 'reconhecer' o que é grave ou que pode vir a se tornar como tal, faz existir, entre eles, uma competição que se expressa no campo da competência em ler os sinais de urgência. Os pacientes se tornam, às vezes, vítimas dessa rivalidade na medida em que são objetos de ordens contraditórias. É o que aconteceu, por exemplo, a um homem de uns 50 anos que chegou em pé no prontosocorro, mancando e com sangue seco no rosto e na calça rasgada. Quando passou a porta de entrada, o primeiro segurança pediu para ele tirar o chapéu: o homem tinha os cabelos cheios de sangue e uma ferida no crânio. Vendo isso, o segurança o mandou direto para área de atendimento médico e falou que faria sua ficha depois. Para ele, então, esse paciente não podia esperar: o que tinha podia ser alguma coisa grave, assim 
comentou comigo. Quando o homem chegou na frente da porta da área de atendimento adulto e tentou entrar, o porteiro ${ }^{4}$ que fica nesse lugar também pediu para ele tirar o chapéu. Olhou para a cabeça e mandou o homem entrar na fila para preencher sua ficha. Achou que ele podia esperar. Como o homem falou que o segurança da entrada tinha dito para ele entrar direto, o porteiro respondeu com autoridade que não era o caso e voltou a lhe indicar a recepção com um dedo firme, direção que o homem seguiu sem insistir.

Numerosas são as situaç̃es em que um guarda se acha mais competente na leitura dos sinais de gravidade do que um outro. Aliás, em última instância, é sempre o que fica na porta da área de atendimento adulto que impõe seu ponto de vista e sua autoridade. Pois é ele que libera, ou não, a entrada do paciente. Presenciei uma situação em que o porteiro da entrada da área de atendimento até ameaçou os seguranças - que tinham aberto a porta no seu lugar para fazer entrar um doente que achavam urgente de botar o paciente fora "caso não for grave".

\section{Os Sinais}

O que alerta esses observadores da sala de espera do pronto-socorro? Quais são os sinais por eles levados a sério? De uma maneira geral, são os mesmos que foram apontados para os profissionais da saúde, porém com diferenças e divergências significativas. Assim, ao contrário do que foi observado com os médicos, as manifestações de sofrimento e de medo têm um alto valor mobilizador para os seguranças que as encaram como indícios de possíveis urgências. Ficam de olho nos pacientes que expressam esse tipo de manifestações e é geralmente para estes que chamam a atenção dos médicos. Para eles, quem está com muita dor não pode esperar; é o que indicam não tanto seus discursos quanto seus comportamentos. Tentam apressar o atendimento dos pacientes que sofrem (especialmente quando se trata de mulheres e crianças) indo primeiro falar com um médico ou um enfermeiro dentro da área de atendimento, ou colocando o paciente direto dentro da área.

Já foi assinalada a preocupação especial de certos guardas com as pessoas se queixando de cólicas renais. Entre as várias situações nas quais presenciei sua importância, teve uma em que um segurança chamou a atenção do médico-chefe do prontosocorro para uma moça que estava de cócoras, encostada na parede e manifestando muita dor. "Ela está com cólica renal", falou para mim antes de ir à procura do médico que a atendeu em seguida. Mas o segurança teve de justificar sua atitude, pois o filho de um outro paciente, sentado em uma cadeira de rodas, reclamou dizendo que estava esperando a vez de seu pai há horas. O guarda the explicou que as dores da cólica renal são "horríveis". O argumento do sofrimento insuportável aparentemente convenceu o filho de que o caso da moça era mais urgente, pois concordou dizendo que, de toda maneira, no caso de seu pai "não tem cura": "está com a doença de chagas" da qual se morre, então "não tem pressa".

De maneira geral, os seguranças são atentos à aparência física e aos comportamentos dos pacientes, assim como às expressões de seu rosto, isto é, a tudo o que ele oferece a ver e a ler: cor, lágrimas, respiração dificil, sangue, dor, medo, pavor, fraqueza etc.: 
[tinha] uma mulher esperando aqui, gritando o tempo todo, estava olhando para ela fazia tempo, de repente parou de gritar. É nesse momento que voltei a olhar para ela, os olhos se fechavam, sabe assim os olhos se fecham, eu vi o momento dela cair, ela começou a cair, chamei o outro segurança, o médico pegou ela, segurei a cabeça dela para não cair no chão, foi levada para dentro.

Vi que estava mal porque a carteira dela caiu no chão e não pegou. Fui ver ela, ela disse que não sabe o que está acontecendo com ela, mas que tem um problema na vista e não vê mais nada. Peguei ela para levar para dentro, mas começou a cair. Segurei a cabeça para não bater no chão.

Você olha, se o paciente estiver ensangüentado, é emergência.

Não tinha dito? Ele chegou morto. Parada cardiaca. O cara está tudo roxo e você viu o sangue que saia da boca?

Faz quarenta dias que trabalho aqui: já vi cinco mortos, três paradas cardiacas $e$ dois esfaqueados. Sei quem é morto já na porta de entrada porque quem tem parada cardiaca é roxo.

Eu olho, eu vejo, se a criança não está acordada, se não estiver..., levo correndo para o PS infantil; isso não significa que se a criança estiver acordada não necessita atendimento, mas ai já não é aquela correria.

Quando o cara chega apavorado, descendo rápido do carro, você já sabe que é emergência.

Estranho, sentada ela parecia bem, e ela parece ruim agora. Não vi.

Você vê esse moço, está com 17 anos. É muito magro, não sei o que ele tem... Aids...

Se os seguranças procuram, no rosto e nos comportamentos dos pacientes, os indícios de uma possível gravidade, eles também se baseiam no que dizem e, neste aspecto, ainda se distinguem dos médicos:

A amiga dela disse para mim que era aborto, que estava sangrando, eu disse:psssittt! Entre direto! Disse que está grávida de cinco meses! ${ }^{3}$

[Uma mãe entra na sala de espera segurando uma menina que parece muito fraca. O segurança vai atrás dela e lhe pergunta]: - O que aconteceu com a menina? - A pressão dela caiu muito, está para baixo, [responde a mãe]. [O segurança]: - Essa entra direto. Qual a idade dela? - 10 anos. [Indica para a mãe a entrada da área de atendimento infantil]

Os pacientes que se queixam de muita dor, de pressão alta ou baixa, de falta de ar, de dor no braço e no peito, assim como as mulheres grávidas que dizem estar com dor, chamam a atenção dos guardas. "As grávidas, as cólicas renais e as crises 
broncopulmonares, acho que esses têm que entrar direto. Quem está com dor no peito, no braço e falta de ar, também. Enfarte", fala um segurança. E para provar que ele está certo, relata-me em seguida uma discussão que teve com uma enfermeira por ter colocado direto na sala de emergência uma mulher que estava na espera. Diz ter tomado essa iniciativa porque, na conversa que teve com a paciente na sala de espera - foi conversar com ela, pois "vi que não estava bem" - ela se queixou de dor no peito e de falta de ar: "isso é enfarte !". Quando a enfermeira viu a paciente na sala de emergência, repreendeu o guarda e mandou a mulher aguardar fora. "Pode esperar, é crise convulsiva, não é enfarte", ela teria afirmado. E a paciente morreu porque, afinal, era um enfarte.

Esse exemplo não somente mostra a importância conferida pelos seguranças a certos sintomas e a atenção que dão à queixa dos pacientes. Indica também uma outra constatação: o fato de deixar aos seguranças um papel tão ativo, importante e primeiro na triagem médica, ${ }^{7}$ acaba desembocando, de vez em quando, em conflitos de competências com os profissionais da saúde (o que também acontece, pelas mesmas razões, com as recepcionistas, como será visto a seguir). A responsabilidade e o papel atribuídos aos seguranças na sala de espera se traduz, em certas ocasiões, pela contestação da apreciação médica: eles acham que sabem melhor da gravidade do estado dos pacientes - que observam e com quem conversam - do que os que "nem olham para eles". Daí também o julgamento severo -- "está errado", "não está certo" - em relação ao que vêem no pronto-socorro, especialmente por parte da equipe médica.

Voltando à exposição dos sinais levados a sério pelos guardas, constata-se que qualquer problema que envolve a cabeça, ou que está nela localizado, também tende a ser considerado como urgente, quer seja manifesto (corte, sangue, inconsciência) ou não (o paciente se queixa de um problema nessa região do corpo: bateu a cabeça, está com muita dor de cabeça, tem problema na vista...). Várias citações já mostraram o quanto "a cabeça" é presente nos seus relatos de casos graves, e especialmente nos de desmaio, sinal de urgência por excelência: "não pode bater a cabeça", "segurei a cabeça para não bater", "qualquer pancada na cabeça é urgência, mesmo que não sangre" etc. A cabeça é a parte do corpo objeto da maior atenção e das suspeitas mais sistemáticas em termo de gravidade. Tudo que the ocorre diretamente (choque, corte, dor) ou que afeta o que é concebido como dependendo dela (consciência, vista) é tido como potencialmente grave. A cabeça tem de ser preservada, imediatamente cuidada: não há pequenos problemas entre os diversos que acontecem com ela.

Da mesma maneira, qualquer pessoa que está com sangue, não só na cabeça, mas em qualquer região do corpo, alerta os seguranças e mobiliza sua atenção, quer sua aparência seja ou não impressionante em termos de ferimento visível, quer seu sangue esteja seco ou que ela esteja sangrando. Muitas vezes procuram apressar o atendimento desses pacientes. O mesmo acontece com as pessoas que não parecem firmes na maneira de andar ou de ficar sentadas.

\section{A Conflança nos Pacientes}

Dito isso, o mais interessante não é tanto insistir na enumeração dos sinais que suscitam a mobilização dos guardas quanto sublinhar que se baseiam no que os pacientes 
dão a ver e dizem: acreditam em seus comportamentos e falas. A escolha do verbo 'acreditar' não é fortuita, pois, o que talvez mais impressione em inúmeras atitudes e falas de médicos e enfermeiras é sua desconfiança nos pacientes. Apresentados e considerados 'ignorantes', 'mentirosos', 'atores', 'preguiçosos', 'fracos', 'espertinhos', que tentam enganar os médicos ou se aproveitar do pronto-socorro para satisfazer necessidades não médicas, ${ }^{8}$ suas queixas, falas e atitudes são suspeitas de falsidade, por ignorância ou por fingimento. Pelo crédito que dão aos pacientes, os seguranças se distinguem nitidamente do conjunto dos profissionais que atuam no pronto-socorro.

Os porteiros, funcionários já antigos do hospital, compartilham e expressam a mesma desconfiança que os profissionais de saúde (as recepcionistas também). Suas falas a respeito dos pacientes são a reprodução do discurso dos médicos. Na perspectiva desses profissionais, apreendida através de suas criticas ao trabalho dos seguranças, suspeitar dos pacientes é uma marca de experiência. Os trechos seguintes de uma conversa que tive com um deles são bem representativos dessa visão, ao mesmo tempo desconfiada e depreciativa, dos pacientes:

Você acabou de pronunciar uma palavra importante: desmaio. É uma das coisas mais importantes que temos que saber reconhecer. Desmaio pode ser emergência, pode ser enfarte, pode ser derrame. O verdadeiro, não o fingido. É importante saber [reconhecer um do outro] para evitar o desgaste do corpo. Em vez de você ter que carregar a pessoa. colocar ela numa maca, ela entra em pé. [Explica que se sabe quando o desmaio estáfingindo porque 'os cilios vibram'. Eque quando a pessoa está desmaiada 'de verdade', se levantar o braço dela acima da cabeça e deixar tombar, ele cai em seu rosto. Enquanto quem finge, que nem 'o psicótico', guarda o braço erguido ou larga no ombro]. Você sabe como fazem os médicos para saber? Eles torcem o mamilo da pessoa, seja homem ou mulher. Já vi, a pessoa desmaiada de verdade, ela não sente nada.

E mais adiante, na conversa:

Não tem ninguém na sexta porque é final de semana, é diversão. O sábado e o domingo é só urgência. Na segunda, o pronto-socorro enche. O cara bebe ofinal de semana todo, enche a cara, perde a hora do serviço e vai para o prontosocorro para conseguir um atestado médico. Ou está se sentindo mal porque bebeu o final de semana todo (...). O problema é a falta de informação. O povo não sabe. Qualquer dor para eles é urgente. O PS é para vir quando você precisa de um exame aprofundado, uma tomografia, um raio-X, senão você vai para o posto de saúde. Mas eles não querem levantar às seis da manhã para marcar uma consulta, então vêm aqui e não podemos recusar eles. (...) Quando eu era moleque, não se ia no médico. Morava num sitio, minha mãe dava remédios caseiros. Tenho duas cicatrizes, uma é plástico quente que caiu no pé, não fui no médico. Hoje, o cara tem um cortinho na mão, já vem aqui! (...) Eles dizem 'passei mal, passei mal', para eles 'passar mal'é ter uma dor, uma dorzinha, na perna, na barriga e eles dizem que passam mal! Eu passo mal quando tenho uma diarréia, uma dor de cabeça forte. Tem pessoas que vêm aqui para uma dor de cabeça que já têm desde uma semana!" 


\section{Preconcetros e Descrinicacio}

Dois tipos de pacientes não suscitam muito dó por parte dos seguranças, bem ao contrário. Pelos que chamam de 'drogados' e 'bêbados' ${ }^{10}$ sentem desprezo e, com eles, seus comportamentos são bem diferentes. Segundo as circunstâncias, ficam rudes, agressivos ou totalmente indiferentes. Também zombam deles com usuários, médicos, enfermeiros cuja cumplicidade, nesses momentos, se assenta nos mesmos preconceitos, amplamente compartilhados. Apesar desses pacientes serem, muitas vezes, coletivamente ignorados, a ponto de parecerem invisíveis na sala de espera do prontosocorro, " eles não deixam de ser discretamente observados pelos seguranças. Porém, não é porque seu estado é considerado como possivelmente urgente, ou podendo vir a se tornar sério. Os guardas estão atentos a eles para reprimir, a tempo, possíveis comportamentos julgados não desejáveis, perturbadores, ou ainda perigosos para os pacientes e o pessoal do pronto-socorro.

Os 'bêbados' e 'drogados' caem fora da categoria dos 'pacientes' e, por consequiência, das categorias da 'urgência' e da 'emergência', pois os seguranças acham que não são doentes na medida em que o estado no qual se encontram, mesmo que ruim, mesmo que grave, é o resultado do que chamam "uma escolha", em outros termos, estão assim porque "querem". São viciados e vício não é doença. Eles só atrapalham o atendimento das outras pessoas que, por serem consideradas 'pacientes', merecem atenção e cuidado. Assim, é comum ouvir, por parte dos seguranças, frases como: "paciente eu respeito. Agora bêbado e drogado, se encarar, apanha" ou, ainda. "vim aqui para trabalhar... e tenho que cuidar de bêbados! E tanta gente aqui, morrendo!". As raras vezes que observei guardas barrando a entrada do pronto-socorro a usuários querendo consultar, tratava-se sempre de pessoas alcoolizadas. Săo também esses pacientes que, muitas vezes, são amarrados em uma maca no meio da sala de espera e deixados assim, no chão e na frente de todo mundo, até serem atendidos. ${ }^{12}$ Os comentários e as reações das pessoas que passaram por essa situação mostram o quanto viveram-na como humilhante.

A desconsideração pelos 'bêbados' evidencia-se nas falas dos seguranças, em seus comportamentos e também nas situações nas quais estão envolvidos. Eis alguns casos representativos não somente de suas atitudes e reações com esse tipo de paciente, mas também do consenso geral no qual elas se inserem:

Caso 1: Um homem de 50 anos chega ao pronto-socorro transportado por uma ambulância do 192. Está alcoolizado e foi encontrado deitado na rua. Desce da ambulância ajudado pelo motorista que o deixa na sala de espera. Vai andando. em equilíbrio muito precário, até uma cadeira onde se senta e põe sua cabeça nos joelhos, cercada pelos braços. E fica lá, sem que ninguém desse a impressão de ter notado sua presença. Depois de quinze minutos, levanta. andando como se fosse cair a cada passo, na indiferença geral. Dirige-se à saída, perde o equilibrio e vai bater várias vezes contra a porta de entrada. Passa ao lado do segurança que não parece vê-lo, e começa a descer a rampa de acesso, cambaleando. Tensa com a situação. pergunto para o segurança da entrada, com quem estou justamente conversando. se não pensa que o homem precisa de ajuda. Só nesse momento parece perceber sua existência e resp̣onde, com indiferença: "é um 
bêbado". Olha para o homem que continua descendo sem firmeza, até o momento em que cai e fíca deitado no chão, na calçada que beira a rampa de acesso. Aí, o segurança vira a cabeça na direção oposta e volta a falar comigo sobre coisas que nâo têm nada a ver com a cena. Como expresso, de mancira insistente, minha preocupação com o homem, agora imóvel no chão, o segurança entra na sala de espera e volta dizendo que avisou alguém. Mas, depois. parece se esquecer dele e ninguém - paciente, acompanhante. funcionário, profissional de saúde - saiu do pronto-socorro para dar uma olhada naquele homem, para leválo de volta à sala de espera, para atendê-lo. Ficou horas deitado na calçada do pronto-socorro, sem receber a mínima atenção, transparente ao mundo que se movimentava em redor dele.

CASo 2: Chega uma ambulância do 192. Através do pára-brisa, o motorista faz o gesto de beber para o segurança da porta de entrada. $\Lambda$ ssinala. dessa maneira. que está levando um paciente alcoolizado e que precisa de auxílio para tirá-lo da ambulância. O segurança resmunga, mas vai ajudá-lo a acordar a pessoa c levá-la para dentro da sala de espera. Aí, o motorista bota o paciente em uma maca. Fste diz que não quer, com insistência, tenta levantar, mas não conscguc, c fica. Voltando para a ambulância, o motorista fala para o segurança descontente: "não tem jeito, estou obrigado a pegar, senão é omissão de socorro". F, vai embora. UIma pessoa na espera fora, que presenciou a cena toda, fala para o segurança: "É segunda!".

Caso 3: Um paciente está sendo contido violentamente. Segundo um enfermeiro, ele está em coma alcoólico. Os enfermeiros o xingam e pisam em seu peito e em seu pescoço. Amarram seus pés e mãos, e quando falta apenas o peito, e portanto não há como o homem se soltar, um dos enfermeiros se utiliza de um lençol. pondo-o embolado no rosto do homem, como se simulasse uma tentativa de asfixiá-10. Os entermeiros riem e se divertem. Os scouranças também. Logo depois, conversando com um dos seguranças, obtenho a seguinte fala: "esse aí é freguês antigo; se deixar, quebra tudo; geralmente são os enfermeiros [que o contêm]". A cena acontece na sala de espera do pronto-socorro adulto, ao lado do pilar. E o homem fica lá amarrado. Os outros pacientes viram a cena, e poucos tiveram reação. Futuramente, viria a saber por um segurança que a intenção do enfermeiro ao pôr o lençol no rosto de quem é contido ś justamente, através do medo de ser sufocado, conseguir acalmar a pessoa. Algumas semanas depois, um guarda vem me perguntar se eu ponho no meu relatório os casos onde os pacientes sảo "maltratados". Uso como exemplo o caso do homem que foi contido com violência, então a conversa prosscgue, cele me relata um outro caso. Um paciente muito nervoso estava sendo contido "de forma errada" pelos enfermeiros, um médico presenciou e os repreendeu. Assim que ficaram sós com o paciente, colocaram um lençol $\mathrm{cm}$ seu rosto para que pudessem aplicar a injeção. Segundo o segurança, é para "dar medo". Assim sendo, tal procedimento se mostra muito "eficiente", porque amedronta a pessoa que mesmo "amarrada corretamente" ainda tem movimentos que dificultam a aplicaçào. O guarda deve ter achado a cena muito humilhante, pois acabou concluindo: "deu uma dó". O cara olhou para o enfermeiro com mágoa! I magina vocé amarrado com pano no rosto! 
CAso 4: X, encarregado de passar ordens para os seguranças, vem pedir que impeçam a entrada de duas pessoas específicas no pronto-socorro. Ao perceber minha presença, enfatiza: "só se vier machucado; isso é respeito com as pessoas que estão ai". Passados alguns minutos, quando $\mathrm{X}$ ainda se encontra na porta, apresenta-se uma das duas pessoas proibidas de entrar. É um homem, com aparência de andarilho e alcoolizado, que chega dizendo que quer "ver o médico". Impedido pelos seguranças de entrar e fazer sua ficha, o homem senta-se ao lado da porta, do lado de fora, e começa a resmungar dizendo que tem direitos. Vem então à porta um médico que dá uma breve olhada no homem, e comenta: "quer fazer ficha na psiquiatria; internação". E vai embora. Um paciente na espera que presenciou a cena exclama: "nossa, que milagre! Um doutor veio aqui ver o paciente!". Mas como depois dessa brevíssima consulta, o homem continua barrado, entendo que o médico deve ter julgado que o caso dele não é do pronto-socorro. Aparentemente livrado da responsabilidade de barrar esse paciente, o segurança comenta: "o médico olhou, ele sabe". Pergunto-lhe se o homem não tem direito a um atendimento, e ele responde: "bêbado assim não; ele quer ser internado". Um outro guarda acrescenta para mim: "sabe qual é a instrução para os seguranças de azul [de empresa]? Para cara pingaiado que encher o saco, dá borrachada no coco". Entendo também algumas frases do homem barrado que fala: "se eu vim aqui, é porque eu preciso, sinto fraqueza, tremedeira, hospital tem que atender". Contrastando com a opinião do primeiro segurança, um porteiro me diz discretamente que não acha certo tal procedimento, que se deveria pelo menos deixar o homem entrar, para então explicarthe que a internação não será feita. Vou falar com o médico que olhou o homem e pergunto se este não tem direito de ser atendido. Responde-me que apenas aguarda a chegada do médico psiquiatra, para em seguida chamar o homem para receber atendimento. Questiono então o segurança que me parece ser, portanto, o responsável pela não entrada do paciente, e este me diz: "hoje ele não vai ser atendido". Afinal, o homem continuou sentado do lado da porta de entrada, e cada vez que identificava alguém de branco chegando ou saindo, levantava e punha-se a pedir atendimento, sendo facilmente dispensado.

No pronto-socorro, os pacientes que, de uma maneira geral e consensual, são pouco levados a sério, objetos de desconsideração e de ironia, são os ditos 'drogados' e 'bêbados', as mulheres que chegam, gritando e/ou chorando, assim como os pacientes (homens ou mulheres) que apresentam um estado de grande nervosismo. Importa assinalar que todos têm em comum serem considerados e designados como 'casos psiquiátricos'.

\section{As Recepcionistas}

Por preencherem as fichas dos pacientes que chegam no pronto-socorro, as recepcionistas desempenham um papel muito importante na triagem. Não receberam nenhuma formação na área médica e dizem geralmente ter aprendido seu trabalho uma vez na função, graças à ajuda de uma recepcionista mais experiente que lhes explicou como e o que fazer. "No inicio, você não sabe o que é, o que não é, fica que nem barata 
tonta!", lembra-se uma delas. São em três na recepção das $7 \mathrm{~h}$ às $19 \mathrm{~h}$. Depois desse horário, chegam outras três que ficam até as $23 \mathrm{~h}$, quando são substituidas por outras duas que trabalham até as $7 \mathrm{~h}$ da manhã. Se os seguranças e porteiros são todos homens, na recepção só trabalham mulheres.

No momento do preenchimento da ficha, as recepcionistas pedem várias informações ao paciente (ou a seu acompanhante). Primeiro, seus dados pessoais: nome, endereço, estado civil, nível de formação escolar. Elas também perguntam a religião para, segundo elas, "saber se a pessoa aceita ou não a transfusão. Assim, no caso de problema, o médico está protegido". Na ficha, a cor do paciente há de ser mencionada, mas para conseguir um dado de tão imediata visibilidade, as recepcionistas não precisam perguntar e os pacientes ignoram a anotação dessa característica. Depois, através de perguntas breves, como "consulta para quê?", "o que aconteceu?", "qual o probiema?", elas obtêm as informaç̃os a partir das quais decidem que tipo de médico o paciente vai consultar (clínico geral ou especialistas) e também avaliam a urgência de seu problema, se ele deve ou não passar na frente de outros. São elas que colocam as fichas nas caixas reservadas aos médicos ${ }^{13} \mathrm{e}$, quando acham que um paciente não pode esperar, colocam sua ficha na frente das outras. Neste caso, acontece também delas chamarem a atenção de um médico ou, ainda, mandarem o paciente entrar direto nas áreas de atendimento.

Eu já sei quem vou levar lá [área de atendimento] e quem vai ficar na sala. You ver o médico na sala de emergência... Cólica de rim, sutura entra direto. $\dot{E}$ emergência por mais leve que seja.

Quando achamos que não é grave, que pode esperar, colocamos na caixa [da triagem clinica geral] para o médico ver e encaminhar: Quando achamos que é grave, o coração, uma dor aqui [aponta o peito], colocamos a ficha dentro [da área de atendimento]. Assim, o médico já sabe. Para sutura também a ficha é dentro.

As vezes a gente se engana, mas, pelo que eles [os pacientes] dizem, dá para saber.

Se for problema de menstruação é o ginecologista, se é uma dor Lmostra a parte de cima do corpolé o clinico geral.

As informações que as recepcionistas conseguem, oralmente, dos pacientes sobre seu problema são pouco numerosas, pois, como veremos mais adiante, eles geralmente respondem brevemente. No momento em que preenchem a ficha, elas se apóiam, também, em elementos de ordem visual e avaliam o estado dos pacientes em função do que elas observam e do que eles dizem. Por exemplo, quando uma mãe quer ser atendida logo, pois segundo ela, seu filho está com muita febre ou com corte na cabeça, elas pedem para dar uma olhada no nenê e, a partir do que decifram visualmente (a expressão no rosto da criança está ruim ou, ao contrário, parece boa), atendem o pedido da mãe -- dizendo para ela entrar direto na área de atendimento infantil - ou năo. A seleção, por especialidades e por grau de urgência, dos pacientes que passam pela recepção é feita em função da avaliação dessas funcionárias que, aliás, não se 
reconhecem em nenhum papel significativo na triagem. Interrogadas a esse respeito, dizem que a triagem começa antes delas, pelos seguranças, e que seu trabalho apenas consiste em "tentar saber o problema do paciente", para já ir encaminhando às respectivas especialidades.

A partir das perguntas que fazem, as recepcionistas revelam o que consideram (possivelmente) grave e urgente e quais são os sinais por elas levados a sério. Eis alguns exemplos de suas conversas com os pacientes no momento do preenchimento das fichas (excluída a parte relativa aos dados pessoais). Trata-se, aí, de pacientes atendidos em seguida pela mesma recepcionista.

P1 [Mulher, 70 anos]: - Tomei um banho, travou a coluna.

$\mathrm{R}$ : - Travou as costas?

P1:-Travou a coluna, dá uma dor!

P2 [Mulher grávida, 34 anos]: - Estou com dor.

R: - Quantos meses?

P2: - Vai fazer nove.

$\mathrm{R}:-$ Está perdendo líquido?

P2: - Não sei, está descendo alguma coisa.

R: - O que aconteceu com o nenê?

P3 [Um casal jovem para seu nenê de 7 meses]: - Está chorando dia e noite.

P4 [Homem, 46 anos]: - Quero passar pelo médico de rim, sei lá..

R:- Tem dor?

P4:-É isso.

$\mathrm{R}$ :- Começou quando a dor?

P4:- Ontem.

[Como pergunto para a recepcionista porque quer saber desde quando começou a dor, cla me responde:- Para passar para o médico se ela for forte $\mathrm{c}$ súbita. A dor dele dá para esperar mais um pouco].

P5 [Homem, 50 anos]: - Quero consultar um dermatologista, o que fazer?

$\mathrm{R}:-$ Tem que agendar.

P5: - Fazer o quê?

R: - Passar pelo posto de saúde e pedir encaminhamento.

$\mathrm{R}:-\mathrm{O}$ que que é?

P6 [Homem, para seu filho de 3 anos] : - Ele está com tosse seca. 
P7 [Mulher, 30 anos]: - Caí duma escada, quebrei dois dedos do pé, até agora não fiz nada.

R: - Há quanto tempo?

P7: - Uma semana.

[Ai, a recepcionista, em dúvida, pergunta para uma colega para qual especialista vai encaminhar a moça, e resolve mandar para o clínico geral. E me explica:-Até quatro, cinco dias, passo para a ortopedia, depois para o clínico geral].

$\mathrm{R}:-\mathrm{O}$ que aconteceu com ela?

P8 [Homem, para sua filha de 4 anos]: -- Ela está vomitando, está com febre. A febre eu contei. Sente tontura.

P9 [Homem para sua mulher]:-Ela tem problema no intestino. É muito ressecada. Onde que encontro um médico?

R: - Aqui é pronto-socorro, só se for grave. Se não, agenda pelo posto de saúde. Aqui quem vai atender é só clínico geral. Agende pelo posto de saúde, para ela ver um especialista.

[Depois da partida do homem, a recepcionista comenta para mim: - Eles não sabem, acham que PS é tudo, que pode resolver tudo].

R:- Para a senhora?

P10 [Mulher, 33 anos, nivel universitário, lendo na fila até ser atendida]: - Sim.

$\mathrm{R}$ : - O que aconteceu?

P10: - Problema de ouvido, não estou ouvindo nada.

P11 [Mulher para sua mãe de 61 anos]: - Ela está ruim. Cheguei, estava fraca, cabeça fraca, desde dezembro que não come. Não pode ficar assim, fillha! Não consegue tomar conta da casa dela.

R: - Vai consultar com o psiquiatra.

P11: - A minha mãe precisa. Ontem já veio e não foi atendida. Tỉnha pedido um clínico geral.

P12 [Homem, 36 anos]:-- Quero consultar de novo.

R:- O que é?

P12:- Acho que é rim.

P13 [Homem, 53 anos]: - Estou com mau jeito nas costas, carreguei peso.

R: - Quando?

P13:- De manhã.

R: - Está com dor de cabeça?

P13: - Não. 
P14 [Homem, para seu sobrinho]: - Meu sobrinho tem que internar, ele é muito ruim.

$\mathrm{R}:-\mathrm{O}$ que tem?

P14: - Sabe... o que tem... como explicar... ele está muito ruim. O caso dele é grave, tem que atender já, que é muito grave.

R: - Tem um acidentado dentro, vai ter que esperar alguns minutinhos.

[Como, depois da partida do homem, pergunto para a recepcionista o que acha que tem o sobrinho, ela me responde: - Tem tudo!]

P15 [Mulher, para sua filha de 5 meses]: - Ela está ruim.

$\mathrm{R}:-\mathrm{O}$ que ela tem?

P15:- Está com febre, grita, chora.

$\mathrm{R}:-\mathrm{O}$ que ela tem?

P16 [Mulher, para sua filha de 6 meses] : - Muita febre.

PI7 [Homem, 40 anos]:- Quero consultar pro joelho.

$\mathrm{R}:-\mathrm{O}$ que aconteceu?

P17: - Já fiz cirurgia, joguei...

R: - Bateu o joelho ou torceu?

P17: - Não, chutei.

R: - O que aconteceu com o senhor João?

P18 [Mulher, para seu marido levado pelos bombeiros]: - Começou inchar as pernas e depois caiu.

R:- O que aconteceu com ela?

P19 [Mulher, para a sua filha de 8 anos]: - Bateu a cabeça. Levei um susto.

$\mathrm{R}$ :-Estava brincando?

P19: - Não, estava descendo a rua. Bateu a cabeça numa caixa de táxi.

$\mathrm{R}$ : Cortou?

P19: - Não furou, sangrou bastante.

R: - Aguarde.

[Comentário da recepcionista para mim: - Minha mãe não me levava para essas besteiras!].

P7: A mulher com os dois dedos quebrados, [de volta na recepção, irritada porque ninguém a atendeu. Queixa-se de que foi dito para ela que o clínico geral ia atender, mas agora "uma mulher" acabou de dizer para ela que "é do ortopedista". Quer saber o que fazer e se vai esperar ainda muito, pois já esperou muito o clínico c se tiver que esperar isso tudo de novo para ver o ortopedista...] 
R: - Moça, o seu caso é do clínico geral. Ortopedia para nós é urgência, para nós o máximo é cinco dias.

P7: - Se eu voltar amanhã, tem problema?

R: - Não.

P7 [indo embora]: - Não acredito, que saco!

[Comentário irritado da recepcionista depois da partida da moça: - Quebrou os dedos há duas semanas! Você acha que é urgência! Reação da recepcionista do lado: - Não é não. Se você passar para o orto, não vai gostar].

\section{Outro dia, outra recepcionista}

R: - Qual é o problema?

P20 [Mulher, para seu nenê que está chorando sem parar]: - Muita febre.

$\mathrm{R}:-\mathrm{O}$ que que ele tem para chorar tanto?

P20: - Acho que é febre.

R: - Será que tem dor?

[O nenê vomita na frente da recepcionista].

Outra R do lado: - Por que chora tanto?

R: - Pode sentar com ele atrás, passa primeiro.

[Chega o médico atuando na triagem infantil que vem buscar as fichas na recepção. A recepcionista que preencheu a ficha do nenê assinala o caso e seu caráter preocupante para o médico, dizendo:-chorando, chorando, chorando demais...].

P21 [Mulher para sua filha de 20 anos]: -É para consultar com o ginecologista.

Ela está grávida, está com dor.

R: - Quantos meses?

P21:- Sete meses. Será que vai demorar? Porque ela tem dor.

$\mathrm{R}:-$ Tem que aguardar.

P22 [Homem, 62 anos]: - É só para medir a pressão. Sinto tonturas...

[O homem começa a tremer, segura-se ao balcão, parece muito mal.]

R: - Você vai passar pelo médico, pode aguardar nos bancos.

[Na fila, alguém pergunta alto se vai durar ainda muito tempo. A recepcionista diz que sim, que é assim para todo mundo. A pessoa então responde, também irritada:- Mas aqui é emergência. Por que demora tanto!?].

P23 [Mulher para a filha de 25 anos]: - Deu crises fortes, está com pé inchado.

R: - Crise de quê? Nervoso?

P23:-Sim. 
[Chega uma outra mulher, P24, que corta a conversa]:

P24:- Pode atender a menina que está passando mal?

R: - Foi o quê?

P24: - Acidente... Enquanto isso [o preenchimento da ficha], ninguém pode atendê-la?

[Chega uma outra mulher, P25]:

P25: - Será que vai demorar para atender, ela se sente muito mal.

R:- O que aconteceu com ele?

P26 [Mulher para seu filho de 8 anos]: - Ele tem o braço inchado.

R:-Caiu?

P26: - Não sei, se foi brincando... o que ele fez.

P27 [Mulher para seus dois filhos, 1 de um ano, o outro de 8 anos, brincando]:

[Como não pude ficar atenta à conversa entre as duas, pergunto à recepcionista 0 que a mãe disse que têm as crianças].

R: - Não sei, acho que nem perguntei.... Geralmente é gripe, febre.

R: - Consulta para quê?

P28 [Uma mulher de 76 anos]: - Porque eu tenho muita dor no peito e nas costas, do lado esquerdo [ela mostra seu lado esquerdo].

$\mathrm{R}$ :- Não é porque a senhora carregou algum peso?

P28:- Não.

[Uma vez a mulher tendo ido embora, a recepcionista pergunta para uma de suas colegas : "- É a gripe, não é?", e encaminha a ficha para o clínico geral].

P29 [Mulher para sua mãe de 62 anos]: - A minha mãe está passando mal, tem pressão alta.

R: - Você mediu?

P29:- Sim, na farmácia.

R: - Quanto?

P29: -15 e 8 acho.

R: - Ela toma uma medicação?

P29:- Não.

R: - Não?

P29:- É a primeira vez.

$\mathrm{R}$ : - A primeira vez? Aguarde, que ela vai ser atendida.

[ $\Lambda$ recepcionista vai falar com um médico e a paciente é atendida em seguida]. 
$\mathrm{R}:-\mathrm{O}$ que aconteceu?

P30 [Homem, 25 anos]: - Ontem, voltando do serviço, uma mulher louca bateu em mim, fugiu, bateu no meu ombro e quebrou dois dentes.

$\mathrm{R}$ : [para outra recepcionista] : - Tem que fazer ocorrência?

Outra R: - Ontem, não!

P31 [Mulher, 27 anos]: - Aquele médico gordão, é ele que atende?

R:-Que gordão?

P31:- Ontem eu vim, é ele que me atendeu.

$\mathrm{R}:-\mathrm{O}$ que foi?

P31:- Inflamação dum canal de urina.

[Comentário da recepcionista depois da partida da paciente: - Você acha que é jeito de falar! Gordão!].

R: - Fala, bem!

P32 [Mulher para sua filha de 5 anos]: - Uma consulta para ela.

$\mathrm{R}$ :-O que aconteceu?

P32: - Está com febre, com gripe, está vomitando.

P33 [Homem para sua irmã de 53 anos]: - Vou explicar, sou de Assis, o médico não acha o que ela tem, então vim aqui.

$\mathrm{R}:-\mathrm{O}$ que ela tem?

P33:- Desmaia, já três vezes.

$\mathrm{R}$ : - O que ela tem hoje?

P33: - Dor no peito e desmaia... Trabalha, mas já não agüenta trabalhar... empregada.

P34 [Mulher, para seu nenê de 1 ano]:

$\mathrm{R}$ : - O que aconteceu?

P34:- Passou o dia sem gosto.

$\mathrm{R}$ : - O que aconteceu [com o nenê], bem?

P35 [Casal, o pai e o nenê de um ano]: - O médico pediu para fazer raio-X... Eu vou tomar injeção.

R: - De quê?

P35:-De Wycillin

R:-Só aguardar.

P35:-Só aguardar?

R: - Só aguardar... A receita é de onde moço? 
P35:- Como?

$\mathrm{R}:-\mathrm{Da}$ onde que é esse encaminhamento?

P35: - Do posto $\mathrm{X}$.

R:- Eles não costumam fazer mais... Com receita de médico particular não pode mais. Você tem que ir para a Santa Casa.

[Comentário da recepcionista depois do casal ter ido embora quieto: - Milagre, ele aceitou. É raro!]

$(\mathrm{P}=$ paciente ou acompanhante; $\mathrm{R}=$ recepcionista $)$

Como se pode constatar, as interações entre pacientes, acompanhantes e recepcionistas são bastante breves. No que diz respeito à identificação do problema do paciente, o diálogo se resume, geralmente, a uma ou duas perguntas e respostas. Portanto, é suficiente para as recepcionistas efetuarem a triagem. Suas perguntas são sucintas e precisas e as falas dos pacientes, gerais e sumárias, são pobres do ponto de vista descritivo: "estou passando mal", "está ruim", "estou com dor".

Quando as recepcionistas obtêm informações orais e/ou visuais que as levam a suspeitar de algum problema sério, geralmente insistem em saber mais sobre os sintomas do paciente e sua situação de saúde, assim como mostram os exemplos P2, P4, P13, P19, P20, P21, P28, P29. Procuram tirar ou confirmar suas dúvidas. Muito atentas, por exemplo, aos sinais que parecem com um início de parto ou de aborto e com os sintomas de enfarte e derrame, mostram-se atentas às pacientes grávidas que estão com dor e interrogam mais os pacientes que se queixam de pressão alta ou baixa, de dor no peito, de dor do lado esquerdo ou no braço esquerdo. O mesmo acontece com os pacientes que dizem ter alguma coisa quebrada, pois, segundo suas instruções, "na ortopedia tudo é urgência, porque não se sabe se for fratura". ${ }^{14}$ De qualquer maneira, "se tiver uma urgência na gineco ou na orto, passa primeiro".

O que é urgente para as recepcionistas (que aliás usam muito pouco o termo emergência ${ }^{15}$ ) é "o que não pode esperar". Essa equivalência também existe para elas e, conforme as representações dos próprios médicos, "o que pode esperar" é tudo que não é repentino nem muito forte. Daí as perguntas "desde quando?", "há quanto tempo?", "faz tempo?", "é a primeira vez?", que fazem em relação à dor, ao problema, ao membro quebrado, cujo paciente se queixa (P4, P7, P13, P33). A partir do momento em que o problema não é de agora, "dá para esperar mais um pouco", como elas mesmo dizem. E, de fato, por decisão das recepcionistas, os pacientes que sofrem de problemas que passam do "hoje" tendem a ficar mais tempo na espera.

A atenção seletiva que manifestam para a possível gravidade de certos sinais é o resultado, de um lado, das indicações e instruções que recebem por parte dos médicos e de sua experiência profissional. Mas, de um outro lado, ela também está ligada ao que toca sua sensibilidade ${ }^{16} \mathrm{e}$, aí, a avaliação escapa nitidamente do registro estritamente médico e pode provocar o descontentamento dos médicos. Aparece claramente na maneira como triam as crianças, e especialmente os nenês, em relação aos outros pacientes: procuram facilitar e acelerar sua entrada na área de atendimento infantil. Aí, ao contrário 
do que acontece com os adultos, certos sinais, quando manifestados pelos nenês, se tornam preocupantes na medida em que existem desde tempo. É o caso, particularmente, do choro. Assim, uma criancinha que não pára de chorar na fila e, depois, na espera, assim como um nenê cujos pais dizem que chora sem parar, desde dias e noites, mobiliza a atenção das recepcionistas e tende a passar na frente dos outros (P20). "Criança, eu tenho dó", dizem umas; "criança, nunca se sabe o que tem", dizem outras. Por isso, liberam com freqüência sua entrada na área de atendimento, com ou sem o acordo prévio dos médicos. Várias vezes, notei a irritação de pediatras em relação a esse comportamento, pois, segundo eles, as recepcionistas mandam os pais com as crianças direto para a área de atendimento para coisas sem importância:"A mãe fala em intoxicação, e a recepcionista leva ao pé da letra e manda direto a criança para o bloco. Ela não olha a criança, elas ficam na queixa da mãe, do pai. Não batem o olho para dar uma olhada na criança!" [Fala de um pediatra expressando sua exasperação a uma enfermeira].

Essa crítica comum mostra que os médicos esperam que as recepcionistas, não só preencham a ficha dos pacientes, mas também atuem na triagem, e isso de maneira certa e eficiente.

Um outro exemplo de que a percepção da urgência não reside só nos sinais que dizem respeito, estritamente, ao problema de saúde e à queixa dos pacientes, são as reações das recepcionistas em relação às pessoas cuja aparência (maneira de ser, de falar, indumentária) revela que pertencem a uma camada social elevada. As interações com esse tipo de pacientes, raros no pronto-socorro, perturbam-nas. Com eles, mostram-se menos diretivas, secas e seguras de $\mathrm{si}$ - tanto no tom de suas perguntas quanto no comportamento geral - do que com os numerosos pacientes de aparência modesta ou miserável. "Quem é bem vestido, tem aparência boa, assusta as recepcionistas que colocam a ficha na frente. O cara passa na frente", comentou comigo um médico do pronto-socorro, confirmando assim minhas observações. E, de fato, esses pacientes nunca ficam por muito tempo na espera. Mas essa realidade não é só devida à solicitude das recepcionistas. Apesar de o médico anteriormente citado acrescentar em seguida: "não aceito, eu olho o horário de chegada nas fichas e respeito a ordem de chegada", ela é o resultado de um consenso geral. No pronto-socorro, independente da natureza de seus problemas e queixas, os pacientes que têm uma 'aparência boa' parecem emergências em si mesmos: eles não podem esperar.

De maneira geral, as recepcionistas são bastante críticas com os usuários, principalmente no que diz respeito ao comportamento (o fato de eles irem ao pronto-socorro em vez do posto de saúde; sua falta de paciência) e ao entendimento (ou melhor, na visão delas, o não entendimento) do que é urgente: "O que eles [os pacientes] têm geralmente não é urgente, não é grave. Atrapalha o trabalho, se chegar uma emergência, estão todos ocupados [os médicos]. Têm que deixar o que eles estão fazendo para atender"; "Olho de peixe, não é urgência. Pode esperar". [Olhando para sua colega, e vendo a expressão duvidosa do rosto dela, a recepcionista acrescenta]: "a não ser inflamado"; "Eu pergunto à pessoa porque ela não vai para o posto de saúde. Ela responde sempre: - porque não tem médicos". "Todo mundo quer ser atendido com urgência. Não tem paciência". 
Elas também julgam negativamente o próprio pronto-socorro. Mas não como os seguranças que denunciam, sobretudo, o comportamento dos profissionais da saúde em relação aos pacientes: o desrespeito, a falta de atenção, de cuidados. O que elas criticam, sobretudo, é a inadequação entre sua função declarada - só atende urgência/ emergência - e sua função real, que, para elas, é de ordem ambulatorial: "A maioria [dos pacientes] é posto de saúde. Tem pessoas que procuram o PS para unha encravada!",; "Acho que aqui não é PS. Todo mundo espera aqui. Tem consultas. Acho errado. Deveria ter um ambulatório ${ }^{18}$ e um PS"; "A obstetrícia no PS teoricamente é só urgência, mas geralmente não é."

Enfim, as recepcionistas lamentam bastante o desconfortável papel de bode expiatório que são levadas a desempenhar no pronto-socorro. ${ }^{19}$ Em contato direto com os usuários, enfrentam seus comentários negativos, suas irritações, suplicações e queixas pela demora, sua pressão para obter um atendimento. Aliás, a presença de uma grade de separação na recepção impõe uma distância e limites físicos entre elas e os pacientes: visa a evitar que o contato, apesar de direto, esteja demais próximo ou se torne confronto. Além disso, as recepcionistas são os emissários de instruções e decisões dos médicos ou da direção do hospital, que desagradam os pacientes. Como aplicam-nas, dão a impressão de estar na sua origem. Vivem mal esse mal-entendido e as conseqüentes reaçōes dos usuários descontentes ou indignados: "Acho errado, não é a gente que deveria despedir, deveria ser alguém da enfermagem. Depois as pessoas acham que nós decidimos, que não queremos fazer a ficha". [Comentário de uma recepcionista depois de ter-se recusado a fazer a ficha de um paciente que queria ser atendido. Portador de uma receita feita por um médico particular, não podia fazer no pronto-socorro o exame nela indicado].

Mas nem sempre assumem o papel de bode expiatório esperado delas. Em certas ocasiões até se negam a desempenhá-lo, como no exemplo seguinte que mostra a reação à instrução dada por um médico que pediu para avisar as mulheres grávidas, em trabalho de parto, que não podiam ser atendidas no pronto-socorro. Eis a fala dele para as recepcionistas: "Queridas, não tem mais leito, não pode nascer mais nenê hoje neste hospital. Podemos atender, mas não dá para fazer parto nem internar. Estamos sem leito. Avisem as pacientes e, no caso de parto, encaminhem elas para o São Francisco. A não ser elas chegarem com a cabeça do nenê entre as pernas e que só tenha que puxar!". Uma vez o médico tendo ido embora, uma das recepcionistas, aprovada pelas outras, comentou: "Não vou dizer nada [às pacientes], não adianta nada. Imagina, ela vai embora e tem o nenê, lá na saída! Não gostaria de ficar no lugar delas! Imagina o desespero! É ele que vai encaminhar. Eu tenho que fazer a ficha, mas não posso encaminhar!". 


\section{NOTAS}

1 Trabalham $12 \mathrm{~h}$ por dia, um dia sim, um dia não (todos os dias pares ou ímpares), das $7 \mathrm{~h}$ às $19 \mathrm{~h}$ para a equipe diurna, com um único intervalo de vinte minutos às $11 \mathrm{~h}$ para almoçar.

2 Ver, em anexo, o mapa do pronto-socorro.

3 No que diz respeito à sala de espera infantil, ninguém vê o que acontece nela. Na configuração física do pronto-socorro, ela ocupa um cantinho escondido no fundo que não dá para ser visto do lugar onde se encontram os seguranças e porteiros e, aliás, de nenhum outro lugar.

4 O mais antigo do qual se tratou anteriormente.

5 Trecho relativo ao caso de uma paciente jovem que chegou com uma amiga e uma criança. Ficou sentada enquanto a amiga foi preencher sua ficha. Ficaram aguardando algum tempo, quando a acompanhante de repente levantou e foi conversar com o segurança. Em seguida, este levou a paciente para a área de atendimento médico onde foi atendida imediatamente. $O$ feto, transportado depois pela equipe médica correndo, da área de atendimento adulto para a área de atendimento infantil, não sobreviveu.

6 Apesar de mostrarem-se sensibilizados pelos pacientes que sofrem, os seguranças deixam geralmente na espera os que se queixam de dores musculares, 'nas costas', 'na perna', 'na coluna'... Esses podem (têm que) esperar, mesmo se "é duro".

7 Contando com sua capacidade e perspicácia em reconhecer quem está mal de quem está bem; contando com eles para serem avisados da presença de pacientes que estão ruins.

8 Como, por exemplo, ir ao pronto-socorro, voltando de uma festa à noite, quando não há mais ônibus, para beneficiar-se de uma ambulância para voltar para casa; obter um atestado médico porque faltou no serviço etc.

9 Bem diferente dos comentários do porteiro sobre o 'passei mal' dos pacientes, é essa explicação dada por um segurança a quem perguntei o que significava a expressão 'passar mal': "a pessoa quer dizer que alguma coisa aconteceu com ela".

10 Mais numerosos do que os "drogados" a virem ou serem levados ao pronto-socorro.

11 É como se não existissem apesar de suas manifestações, às vezes, gritantes.

12 É o caso, também, de homens não alcoolizados que chegam em estado de grande agitação.

13 O caminho seguido por essas fichas mereceria, em si, uma observação aprofundada. Teoricamente, é a ordem de chegada que prevalece na ordenação das fichas e, por conseqüência, na chamada dos pacientes. Mas a observação revela que há fichas que desaparecem ou que não são encaminhadas para os médicos (o que não é raro, o paciente ficando assim esquecido); há fichas de pacientes que chegaram há pouco na frente de outros que chegaram bem antes, isso sem que os primeiros estejam 
padecendo de um problema considerado mais urgente (a "teórica" ordem de chamada virando uma ordem sem muita ordem). Há também momentos em que a sala de espera está cheia e, entretanto, não há nenhuma ficha nas caixas dos médicos, mas também elas não estão com eles, nem com os enfermeiros. As fichas seguem percursos escuros que sublinham a necessidade de uma investigação requintada do que acontece com elas. É claro que o desaparecimento ou o não encaminhamento de fichas tem conseqüências na triagem, pois os pacientes cuja ficha não está entregue para o médico esperam muito. Foi o caso, por exemplo, de uma paciente grávida de 8 meses, acompanhada pelo marido, que, depois de duas horas e meia de espera, foi saber o motivo da demora. "Fomos informados", contou o marido, de que a recepcionista havia "esquecido" de encaminhar a ficha. Após a reclamação, a mulher foi prontamente chamada.

14 Segundo as instruções, é da competência da ortopedia se o paciente consultar no prazo máximo de cinco dias depois do acidente. Depois passa a ser da clínica geral.

15 As poucas vezes que as escutei usarem espontaneamente da palavra 'emergência' foi para designar pacientes acidentados.

16 Como, aliás, é o caso de todos os agentes - médicos e não médicos - que atuam na urgência/emergência (fora e dentro do pronto-socorro).

17 A unha encravada é muito utilizada pelo pessoal do pronto-socorro (médicos incluídos) como o exemplo, por excelência, de problema não urgente, de recurso não justificado ao pronto-socorro.

18 Já há um ambulatório no próprio hospital. Quando a recepcionista fala em 'ambulatório' e PS, ela quer dizer um serviço de pronto-atendimento de tipo ambulatorial para tudo que não é urgente e um pronto-socorro somente para as urgências/ emergências.

Que os seguranças e porteiros também desempenham num grau menor. 


\section{6 \\ "Será que É? Será que Não É?": a perspectiva dos atendentes}

Distante do pronto-socorro, onde suas ambulâncias não param de chegar, fica a Central telefônica de Atendimento às Urgências/Emergências - dita mais simplesmente, Central de Ambulâncias, ou ainda, 192. Agentes importantes da triagem das urgências, seus dois atendentes trabalham apenas durante o dia; à noite, são os próprios motoristas de ambulância que atendem as chamadas telefônicas.

Quando começaram a atuar no 192, nenhum dos dois atendentes tinha sido formado para esse tipo de trabalho. Aliás, desde o início, seus cargos declarados não refletem sua função e responsabilidade reais, a saber: atender as chamadas e triar os pedidos de ajuda, pois eles são, respectivamente, 'mensageiro' e 'escriturária'.

O mesmo pode ser dito dos motoristas da Central que são muito mais do que deixa inferir seu cargo oficial.' Não só dirigem os veículos, mas têm formação em suporte básico de vida, entram nas casas dos pacientes, cuidam deles até sua chegada no pronto-socorro, negociam com os que são recalcitrantes, ${ }^{2}$ acalmam com bastante habilidade a violência e o desespero, atendem as chamadas à noite, consertam as ambulâncias etc., sem esquecer o que se tornou, por força das circunstâncias, sua grande especialidade: fazer partos, pois muitos nenês nascem nas ambulâncias do 192 . Com o salário e o cargo declarado que têm, não recebem reconhecimento pelo verdadeiro trabalho que cumprem, exceto, em certa medida, pelos partos praticados, objetos de artigos na impressa local e, às vezes, de votos de congratulações da Câmara Municipal.

Porém, sem as múltiplas competências desses motoristas polivalentes, a Central não funcionaria. Se eles só dirigissem e os atendentes-triadores só fizessem o trabalho de um mensageiro e de uma escriturária não haveria atendimento nenhum no 192 . A Central só atende a população à proporção que todos seus profissionais usam de competências que foram desenvolvendo na experiência das funções reais que desempenham. Nessas condições, não é de se estranhar que motoristas e atendentes não se sintam reconhecidos em seu justo valor: nem pela população que valoriza muito mais o Resgate do Corpo de Bombeiros, nem pela prefeitura e nem pela direção do Hospital das Clínicas.

Os magros recursos do 192 e a precariedade material com a qual seu pessoal tem de trabalhar são a tradução concreta de um descaso real. Por exemplo, não se pode fazer nenhuma ligação direta a partir da Central, a não ser para a telefonista do Hospital das Clínicas. Se precisar telefonar para qualquer outro lugar (polícia, bombeiros), é preciso 
sair à rua e ligar de um orelhão ou pedir para a telefonista do Hospital das Clínicas fazer a ligação.

Os motoristas trabalharam durante anos sem rádio comunicação nas ambulâncias. Andavam pelas ruas sem comunicação com a Central, a não ser ligando de um telefone público. Eles conseguiram os rádios graças à ajuda de algumas empresas privadas da cidade, mas ainda devem descer da ambulância à procura de um orelhão para entrar em contato, por exemplo, com a policia, quando julgam necessária sua presença no lugar (o que representa uma situação bastante comum). Além disso, as ambulâncias estão sempre no conserto, ${ }^{3}$ e quando os motoristas, depois de certas intervenções, têm de lavar e desinfetar a parte traseira da ambulância (porque está com sangue, por exemplo) fazem-no com uma mangueira na beira da calçada, pois a rua é o único lugar do qual dispõe a Central para estacionar seus veículos. Entre estes, múltiplos são os exemplos que revelam a situação de escassez na qual se encontra e atua o 192.

\title{
Formación dos atendentes e Natureza das Cilamadas
}

Quando começou a trabalhar no 192, o atendente 1 contou com a ajuda do chefe da Central e de uma outra funcionária que lhe explicavam, segundo suas próprias palavras, "corno é que atende e os procedimentos":

\begin{abstract}
Entrei como mensageiro na Central de Ambulância. Quando entrei no hospital tinha outros cargos para mensageiro... arquivar documentos, levar na diretoria. mandar algum documento da chefia para a diretoria, dessas coisas... mas como tinha uma vaga na Central de Ambulância sobrando, ai me colocaram na Central de Ambulância.
\end{abstract}

Fazia um mês que trabalhava na Central, quando:

veio a Clara. lá da preventiva, ela veio falar para mim se eu queria fazer um curso junto com o Resgate, que era só os bombeiros, os funcionários do Resgate e eu sozinho, sem nenhum outro funcionário da Central de Ambulância. Ai fizo curso de pronto-socorrismo... Já faz cinco anos.

Quando a conheci, a atendente 2 atuava na Central havia um ano. Antes, era escriturária em um laboratório de patologia. Desde a sua chegada, não tinha recebido nenhuma formação na área médica, nenhum curso de pronto-socorrismo. Conta que foi o atendente I que "ensinou" para ela: "Eu fui assim, pegando com ele! Vendo que pergunta que ele faz".

Os atendentes recebem ligações e pedidos de várias ordens: entre eles, os ligados a questões de saúde. Os erros e trotes são muito numerosos. Os primeiros são de todo tipo: erros na discagem de outros números parecidos; telefonemas provenientes de outros estados do Brasil para saber do tempo, para falar com um particular; erros de encaminhamento da própria central telefônica etc... Os trotes acontecem por parte de adultos e, sobretudo, de crianças em horários que geralmente correspondem à saída das escolas. O 192 sendo um número gratuito, pode-se chamar sem custo de qualquer orelhão. Eis alguns exemplos de erros e de trotes bastante comuns: 
ERros

A: - Central de Ambulância, bom dia!

S: - Você tem o número de telefone da central de artigo de pesca?

A: - Não. Você tem de ligar pro 102, informaçōes.

S: - Obrigado.

A: - De nada.

A: - Central de Ambulância, boa tarde!

S: - Olha, eu quero saber do número a cobrar.

A: - Eu não sei, informaçôes é 102.

S: - Quê?

A: -102 .

S: -109 ?

A: -102 .

S: - Está bem, obrigada!

( $\mathrm{S}=$ Solicitante; $\mathrm{A}=$ Atendente $)$

TROTR:

A: - Alô?

$\mathrm{S}$ [criança]: -Quem fala?

A: - Com quem quer falar?

S: - Com o senhor.

A: $-\mathrm{Oi}$ ?

S: - Alô, quem fala?

A: - Com quem vocé quer falar?

S: - Com o José.

A: - Não tem nenhum José aqui não,

S: - É o senhor.

A: - Oh! Você pára de encher a paciência aqui, porque senão eu vou mandar a policia ir pegar você aí!

S: - Hein?

A: - Eu vou mandar a PM dar uma passadinha aí para ver o que está acontecendo.

[A criança desliga].

$(\mathrm{S}=$ Solicitante; $\mathrm{A}=\mathrm{A}$ tendente $)$

O que cai de menos na Central são chamadas diretamente ligadas a problemas de saúde. E se delas ainda se extraem pedidos de transferência de um paciente para outro 
hospital, e aqueles cujo atendimento é da competência declarada do Bem-Estar Social ${ }^{4}$ (serviço social da prefeitura), chega-se à conclusão que as solicitações de ajuda urgente para problemas de saúde e acidentes representam a minoria das chamadas recebidas pela Central, cuja função declarada é atender as urgências e as emergências, como está escrito em suas ambulâncias. Mesmo assim, essas chamadas não deixam de ser numerosas.

\section{A Triagem pelo Telefone}

A partir do que diz o solicitante, os atendentes tentam identificar o problema de saúde e avaliar seu nível de gravidade para saberem se há urgência ou não em mandar uma ambulância. À diferença dos vários agentes da triagem que atuam no prontosocorro, eles não podem se basear em nenhum elemento visual de apreciação. Só dispõem da fala dos solicitantes. Além disso, também procuram discernir se o pedido não é falso. Sendo numerosos os trotes recebidos pela Central, essa preocupação não é secundária. A avaliação dos atendentes da Central, então, é dupla: visa a identificar não somente sinais de urgência, mas também eventuais indícios de mentira.

\section{INSEGURANĢA}

Como as recepcionistas do pronto-socorro do Hospital das Clínicas, os atendentes da Central de Ambulâncias lembram o quanto ficavam perdidos no início, isto é, o quanto era árduo saber "o que é" e "o que não é":

Mais dificil no inicio era a emergência mesmo, que era essa parte de enfarte, gestante... já não... Na hora, sim, posso anotar, aguardar, só que eu não tinha noção da gravidade. Mas depois que fiz o curso [de pronto-socorrismo], ai já fiquei mais assim... conhecendo o curso ai já melhorei. Mas antigamente o que eu tinha mais preocupação, era a parte de emergência mesmo... Para reconhecer na chamada... A pessoa ligava para a gente aqui, eu ficava assim... Será que é? Será que não é?... Ficava na dúvida, não sabia mais ou menos assim o que estava acontecendo do outro lado da linha. Ai com esse curso que eu fiz com a Clara, já deu para ter noção. (....) Tem os trotes também. Puxa! Às vezes, eu fico até assim... Na hora que estou conversando com a pessoa, estou achando que é trote. No começo era assim. Achava tudo trote. Depois é que eu comecei a conversar bastante com a pessoa. Eu faço de novo as mesmas perguntas para ver se a pessoa responde igual. (...) Emergência, você tem que conversar bastante com a pessoa, ver o que está acontecendo. Às vezes, eu fico assim na dúvida... será que é? (...) Eu entrei aqui como mensageiro... No começo... eu conversava com a pessoa, eu achava que não era nada. Depois que eu fiz o curso lá, com os professores da faculdade, que eu vi que podia ser coisa mais... assim... grave, mais de... responsabilidade mesmo. (Atendente 1)

No começo, eu achava assim, que toda chamada fosse urgente. Quando eu pegava o telefone, estava meio perdida, eu achava que tudo era urgente. Ai, com 
o tempo, fii percebendo que coisinhas corriqueiras, que podem até esperar um pouco mais, você pode segurar um pouco mais, não é! (...) Coisas corriqueiras, febre, dor de barriga, dor de cabeça, dor abdominal... Um machucado, cortouo pé assim, não grave, um corte simplesmente (...) Agora dá para saber melhor, agora, sim. Tipo assim, o que é mais urgente ou não é! O que é mentira também. Pelo telefone. Só que eu acho que não é o ideal, não é! O certo é você ir lá e constatar. (Atendente 2)

No início, então, um julgava que tudo era 'trote' ou 'nada', enquanto a outra achava tudo "urgente'. Mas, afirmam os dois, "com o curso" ou "com o tempo", chegaram a identificar melhor "o que é" e "o que não é". Hoje, sentem-se mais firmes e tranqüilos na triagem e na conseqüente decisão de mandar, com ou sem pressa, as ambulâncias. Entretanto, eles concordam que, mesmo assim, há vezes em que ficam na dúvida e que, afinal, nunca dá para saber, com certeza, "o que acontece do outro lado da linha":

Muitas vezes não dá para saber o que é. Que nem essa ligação agora. Se fosse um médico, ele iria falar que é... sei lá... pode ser problema que ela teve bebê ou estava com infecção por dentro, acabou... Eu mesmo se fosse médico... Deveria ter um médico como triador: não um mensageiro. (Atendente 1)

No fundo, você nunca sabe se é ou não é. Mas assim, pelo conversar com as pessoas... então você sabe aquilo que você manda primeiro, aquilo que você acha que pode esperar um pouquinho mais... assim você tem que mandar, não é? Porque desde que ligou, você tem que mandar, tem que dar a prioridade àquilo que você acha um pouco mais..., pelo que você conversou com ela... apesar que eu acho que pela triagem não dá para saber: Tem que ir no local e ver. (Atendente 2)

Os atendentes sabem que seus meios de avaliação são limitados: de um lado, pela ausência de informações visuais que caracteriza sua triagem; do outro, pela falta de competência médica que sentem e que ainda aumenta seu sentimento de insegurança e suas dúvidas.

\section{Meios de Identificaçĩo e Critérios de Apreciação}

Apesar das dúvidas, os atendentes da Central de Ambulâncias não deixam de tomar decisões em resposta aos pedidos de ajuda. Quais são, então, as técnicas que foram desenvolvendo para reconhecer um trote e identificar uma possível urgência no telefone? E quais são as informações e os sinais para eles significativos?

Os atendentes insistem na importância de suas conversas com os solicitantes. Procuram alimentá-las e orientá-las de maneira a obter dados sobre o problema que motiva a chamada e a recolher o conjunto de informações indispensáveis para o envio de uma ambulância (nomes do solicitante e do paciente, localização de endereço), ${ }^{5} 0$ que não é sempre fácil, como veremos. 
Os sinais e os meios de verificação que levam os atendentes a discernir uma chamada séria de um trote são na maioria das vezes muito sutis, tendo em vista que só contam com a voz e os dizeres do solicitante. Desse modo, distinguir uma chamada séria de uma brincadeira despropositada requer experiência, como pude constatar ao escutar as conversas entre solicitantes e atendentes no telefone:

Quanto ao trote, eu percebo quando a pessoa começa a gaguejar um pouco... ou mesmo no nome... não fornece mais detalhes do problema e fica batendo na mesma tecla, não dá pormenores. Que dá a entender que não é real. Pois às vezes não bate coisa com coisa. 'Dor de cabeça?. Desde que horas?, E tomou alguma coisa?, Fez isso?, Fez aquilo? ', sabe! Então eu percebo assim, se é um trote... Já começa no horário. Não bate nada com nada. Se tomou alguma coisa, às vezes não é o remédio certo para aquilo, tipo assim. (Atendente 2)

A maioria dos trotes que liga aqui, a pessoa passa o nome da rua, só que é de outro bairro, não tem nada ver. A maioria dos bairros aqui de Marilia, eu conheço todos já. No inicio, tinha dificuldade, tinha que olhar no mapa, confirmar pelo mapa. Agora não, se você me perguntar qualquer rua, te falo qual bairro que é. Só se for um bairro novo de casas populares que não dá para saber. Então às vezes eu pergunto para a pessoa 'o que está acontecendo?', 'ah, fulano de tal desmaiou', 'mas o senhor sabe qual é o problema dele, tem problema de desmaio, tem problema de saúde grave, faz algum tratamento?', essas coisas. Ai a pessoa vai falando. Ai no fim, 'você sabe o nome dele completo?', 'é, é senhor fulano', 'mas o quê você é dele?', se ele diz 'sou irmão', 'e você não sabe o sobrenome?', ai fico naquela dúvida, você não sabe se é parente, se é vizinho, ai você vai conversando com a pessoa, vai fazendo de novo as mesmas perguntas para ver se a pessoa responde a mesma coisa ou eu digo: 'dá para aguardar, não tenho ambulância'; às vezes eu falo: 'não tem ambulância na hora', mas a ambulância está aqui, eu falo só para ver a reação da pessoa do outro lado, para ver se tem uma pessoa realmente desmaiada... estou testando para ver se não é trote mesmo. (Atendente 1)

Fora os trotes, há também as chamadas dos solicitantes que exageram e até inventam os sintomas para conseguir ou apressar a chegada da ambulância no lugar; ou, ainda, que evitam assinalar elementos que poderiam inviabilizar sua disponibilização. Agem assim, muitas vezes, porque estão com receio de seu pedido não ser atendido (ou ser atendido sem pressa) se contarem o verdadeiro problema (o paciente está alcoolizado, por exemplo) ou se revelarem o motivo real da chamada (o paciente não está mal, mas quer ir ao pronto-socorro fazer uma consulta). Esses solicitantes fazem uma descrição mais assustadora do que é na realidade o estado da pessoa para quem ligam: dizem que está desmaiada, que não pode ficar em pé, que bateu a cabeça, que está sangrando, sintomas que, de fato, mobilizam a atenção dos atendentes, tendo em vista que os consideram como possíveis sinais de um problema grave.

As pessoas usam o lado exagerado da coisa para ter uma ambulância. Por exemplo, uma febre: 'ah, está com tantos graus!'. O que leva a uma convulsão, tal... No caso de diarréia, fraqueza: 'não está parando em pé', 'tem que ir'e tal... 
Coisas que, na verdade, você não sabe se é real ou não por telefone, mas eles usam assim, o lado exagerado da coisa. (Atendente 2)

A pessoa te diz: 'ah, está desmaiado!'. Você chega lá, não está desmaiado. Às vezes, a pessoa mente no telefone para que a ambulância chegue mais depressa no local. (Atendente 1)

Numerosas são as saídas de ambulâncias enviadas para um caso cuja descrição preocupante tem pouco a ver com a situação real, descoberta uma vez no lugar. Por exemplo, é comum a Central ser acionada para mulheres grávidas de 9 meses, descritas como estando para dar a luz, na cama com muitas dores e, quando a ambulância chega ao lugar, as ditas mulheres estarem esperando em pé na frente da porta de sua casa, uma sacola plástica na mão com suas coisas, aparentemente bem e todas preparadas para ir ao hospital fazer o parto. Esses casos são tão habituais que os motoristas dão o nome de "sacoleiras" a essas pacientes, por causa da sacola plástica que sempre carregam.

No que diz respeito à avaliação de urgência, os atendentes tentam determinar o problema e sua gravidade por meio de perguntas precisas. Sua apreciação se baseia ao mesmo tempo sobre a situação e os sintomas descritos e sobre o comportamento e as reações do solicitante no telefone cuja atitude os atendentes consideram bastante reveladora. Assim, por exemplo, seu nervosismo é interpretado como sinal de gravidade: a angústia, o desespero que o solicitante passa convence os atendentes de que o problema "não pode esperar". ${ }^{6}$ Eles mesmos afirmam: "Quando a pessoa está realmente nervosa no telefone, é que o caso é de extrema urgência. Aí, eu mando a ambulância na hora" (Atendente 1); "Todo caso grave mesmo que você vê por telefone com a pessoa, a pessoa conversando com você, vê que ela está assim apavorada, desesperada, você vê que é uma emergência, você manda na hora" (Atendente 2).

Mesmo que seja por telefone, você se sente um pouco ao lado da pessoa, a maneira que ela fala para você, se ela está desesperada, é que é grave. Você sente o problema dela assim, tipo 'olha, ele tem isso que é doença grave', tipo 'não está se alimentando, caiu a sonda, não consegue andar, não pára de pé'. Então, mesmo que seja por telefone, você pega um pouquinho desse problema, mesmo que a pessoa do outro lado, você não conhece, mas você sabe que tem pessoas que têm esse tipo de problema. A partir do momento que eu converso, eu sinto a pessoa, o problema dela, que ela passa para mim (...) Então, são coisas do tipo grave, que a gente fica sabendo por meio da triagem. Por mim, se eu tivesse uma ambulância naquela hora, eu quero mandar logo, porque quero que vai logo para curar, para resolver de vez esse problema. Você vê a pessoa chorando ou 'pelo amor de Deus!', sabe! (Atendente 2)

A tranqüilidade do solicitante significa que o problema, apesar de ser apresentado como urgente, não é tão urgente assim e pode esperar. $O$ fato de não pedir, com insistência, a chegada apressada da ambulância, é também interpretada dessa maneira. Tendo provocado a fala do atendente 1 a respeito dessas observações, este confirma e explica: 
Quando eu digo que vai demorar, 'dá para aguardar?'. 'ah, dá para aguardar!', então você vai ver que o desmaio, que ela falou, não é tão grave assim, vai ver que o cara nem é desmaiado. (...) Desmaio dá para aguardar? Não dá. Tem que ir na hora. Então, às vezes, você vê se é emergência ou se não é. Às vezes, uma pessoa desmaiada que a pessoa fala que dá para aguardar meia-hora, uma hora, não é bem desmaiada, deve ser algum mal súbito que deu, depois voltou a si, já está melhor, só está precisando de procedimento médico no hospital. (...) Quando a pessoa fala 'ela está desmaiada aqui, já faz meia hora que ela está desmaiada', ai eu vejo que não é tão assim... Ai eu falo: 'mas como está a pessoa, está desmaiada ainda?'. Eu falo para a pessoa 'ah, não tem ambulância, dá para aguardar?'. E a pessoa fala 'não, não, preciso urgente'; falo 'então, senhora, vê com o Resgate, 193, vê se eles mandam um carro, no momento realmente eu não tenho'. Ai, às vezes, a pessoa fala 'ah, não! Dá para aguardar uma meia-hora, vinte minutos, dá para aguardar'. Então para mim, para mim que converso direto com a pessoa no telefone, no meu sentido, eu acho que não é tão grave assim.

\section{Sinals la Obstáculos para a Avaliaçä́o}

No que diz respeito, mais especificamente, ao problema de saúde descrito no telefonema, os sinais que mobilizam os atendentes são os que já foram apontados nas outras categorias de triadores. Quando o solicitante fala que a pessoa está desmaiada, inconsciente, que não "pára em pé" ou não anda, que está com febre alta, que sente dor no peito, falta de ar, que caiu, perde sangue, está com alguma coisa quebrada, com muita dor, que se trata de uma mulher grávida, ele chama a atenção dos atendentes que procuram fazer mais perguntas para confirmar ou infirmar a suspeita de gravidade que levantou sua fala.

Eis seis exemplos representativos de chamadas recebidas pela Central que desembocaram na decisão, por parte do atendente, de mandar uma ambulância no lugar com rapidez (Exemplos 1 e 2) e sem pressa (Exemplos 3, 4, 5, 6). Mostram o tipo de perguntas feitas sobre o paciente, sua identidade, estado de saúde e de espírito; sobre o solicitante e o acompanhante, ${ }^{7}$ e também sobre a situação em que ocorreu (se manifestou) o problema. As perguntas visam a precisar a necessidade ou não de uma intervenção rápida.

EXEMPI01:

A: - Central de Ambulância, bom dia!

S: - Bom dia! Olha, tem uma moça aqui, minha vizinha, está grávida, acho que está para ganhar nenê! Porque ela está com dor e pediu para chamar.

A:- Está de 9 meses?

S: -9 meses.

A: - Está com dor desde que horas?

S: - Desde cedo.

A:-Desde cedo. É o primeiro filho? 
S: -É o segundo.

A: - Quantos anos ela tem?

S: - Acho que é 29, não tenho certeza.

A: - E como ela se chama?

S: - Ana Cristina de Oliveira Silva.

A: - Quem está falando?

S:- Rosa de Oliveira Rubim.

A:- Rubim?

S: - Isso!

A: - Que bairro que é?

S:-Coimbra!

A: - Que rua que é?

S: - Rua Eduardo Neves, 135.

A: - Ela está com dor e sangramento?

S: - Sangramento não sei.

A: - Já está com 9 meses?

S: - Está.

A: - Está com dor assim, de quantos em quantos minutos?

S: - Direto!

A: - Está bem, então! É só aguardar, estou mandando jả.

S:-Obrigada.

A: - De nada, tchau!

$(\mathrm{A}=$ Atendente $; \mathrm{S}=$ solicitante $)$

EXEMPIO 2:

A:-Central de Ambulância, boa tarde!

S: - Alô, estou precisando de um cano... [falando para outra pessoa]

A: - Qual é o problema aí, o que está acontecendo?

S: - Não, minha avó caiu da escada!

A: - Caiu da escada?

S: $-\dot{E}$, num sobrado.

A: - Está ainda no chão, ou já levantou?

S: - Está no chão desmaiada, bateu a cabeça, ela está bêbada.

A: - Quem está falando?

S: - Hein?

A: - Quem está falando?

S: -É o dono do bar, é o Rodrigo.

A: - Rodrigo do quê? 
S: - Hein?

A: - Rodrigo do quê?

S: - Espera aí, eu estou saindo agora de manhã... [fałando para outra pessoa].

A:- Hein?

S: - Eu moro na casa do outro lado, mas que é...é o Jorge Bispo.

A:-E quem que é esse Rodrigo?

S: - Rodrigo é o dono do bar. Você quer ainda resgatar ou não?

A: - Não?! Também o senhor precisa fazer minha folha de ambulância para mandar a ambulância aí. Que rua que é?

S: - Rua Presidente Vargas, n. 53.

A:-Rua Presidente Vargas, n.53. Está ok! Vou mandar uma ambulância aí para resgatar a paciente.

S: -45 .

A: -53 ou 45 ?

S: -45 .

A: - Está bom, então! O senhor aguarde aí com ela.

S: - É expresso ou não?

A: - Eu vou mandar, estou mandando.

S: - Vou comprar...

A:-O senhor vai aguardar ou vai deixar alguém aí?

S: - Não sei! Porque o rapaz estava sc estrebuchando no chão, bateu a cabeça!

A: - O senhor é que sabe, já estou mandando a ambulância.

S: - Então, manda já, então!

A: - Está bem!

$(\mathrm{A}=$ Atendente $; \mathrm{S}=$ solicitante $)$

ENE:MP10 3:

A:- Central de Ambulância, boa tarde!

$\mathrm{S}$ : - É para meu filho.

A: - O que que ele tem?

$\mathrm{S}$ : - Está com falta de ar.

A: - Ele está com falta de ar há quanto tempo?

S: - Desde ontem.

A: - Desde ontem à noite?

$\mathrm{S}:-\dot{\mathrm{E}}$.

A: - Você já levou ele em algum centro de saúde ou não?

S: - Não, ainda não!

A: - De que bairro você está falando? 
S: -- Jânio Quadros.

A: - Do Jânio Quadros. Ele tem sempre essas crises ou não?

S:- Hein?

A: - Ele tem sempre essas crises?

S: - Sempre teve.

A: - E hoje está bastante atacado?

S:-Está.

A:- Você acha que inalação não vai cortar?

S: $-\ldots$

A: - Quantos anos têm?

S: - Tem 9 anos.

A: - E o posto de saúde, é próximo daí ou não?

$\mathrm{S}:-\mathrm{Não}$, fica tão longe!

A: - Você não quer levar primeiro esse menino no posto de saúde e de lá entregaria para a gente?

S: - Não. Levo esse menino direto para as Clínicas.

A: - Porque você não leva no posto?

S: - Não, nāo!!!

A: - Você não confia no posto?

S: - Eu, não. Sempre levei para as Clínicas.

A: - Um minutinho então, eu vou anotar. Qual é o seu nome?

S: - Cilé.

A:- E o nome da criança?

S: - Pedro...

A: - Que rua que é?

S: - Rua Francisco Xavier de Moraes.

A: - Onde fica?

S: $-\ldots$

A:-Que número?

$\mathrm{S}:-1513$.

A: - Rua Francisco Xavier de Moraes.

S:--é.

A: - Então, está bom! É favela ou não?

S: - Não, é uma chácara!

A: - Então está bem, a gente manda aí. Deixa ele prontinho.

S: - Está bom!

A: - Até logo.

$(\mathrm{A}=$ Atendente $; \mathrm{S}=$ solicitante $)$ 
EXI:NPI0 4:

A: - Central de Ambulância, bom dia!

S: - Bom dia, por favor, daria para você mandar uma ambulância aqui na Salvador Salgueiro n. 340 ?

A: - O que está acontecendo?

$\mathrm{S}$ :-É que tem um senhor que está muito ruim, aqui no fundo!

A: - Qual é o problema dele?

$\mathrm{S}$ : - Ah, espera aí só um pouquinho! Qual é o problema mesmo seu Manoel? Ele está muito... Não sei se ele bebeu demais, não sei, acho que tem que internar ele!

A:-É o seguinte, agora não tenho ambulância, vai demorar um pouquinho. Vai ter que me ligar mais tarde!

$\mathrm{S}$ : - Vai demorar quantos minutos?

A: - Quarenta minutos, mais ou menos.

S: - Nossa! Mas toda vez que chamo a ambulância demora quarenta minutos. Por que será que acontece isso?

A: - Não tenho ambulância agora!

S: - Só daqui a quarenta minutos, então?

A: $-E$ E... é na Salvador Salgueiro, que número que é?

S: -340 , no fundo.

A: - Qual é o problema dele?

S: - É um senhor que, sei lá, acho que bebeu demais, é para internar ele!

A: - Mas quem vai vir com ele?

$\mathrm{S}$ [pergunta a alguém que está perto]: - Quem vai com ele?... Diz que ele vai sozinho!

A: - Não, sozinho não dá para trazer ele. Ele não está inconsciente? Como que ele vai dar os dados na hora que for fazer a ficha?

$\mathrm{S}$ [Falando para outra pessoa]:- Está falando que é para alguém ir junto para dar os dados dele lá no hospital, dar o nome... ele está consciente? Ele pode fazer isso?... Consciente ele está!

A: - Ele quer vir para o hospital?

$\mathrm{S}$ [para o paciente]: - Está querendo ir, seu Manoel? Está querendo, ele pediu para chamar a ambulância, para internar ele. Ele mesmo está querendo se internar!

A: - Como que é o nome dele?

S: - Cirço. O sobrenome, eu não sei.

A: - Quem é que está aí do lado conversando com a senhora?

S: - É um rapaz que também mandou chamar a ambulância.

A: - Então... mas ele não sabe o nome completo?

S: - Nós só tratamos ele por Círço aqui.

A: - E não tem ninguém da familia dele que possa passar os dados?

S : - Então, só chamamos ele por Cirço... Vai demorar, então? 
A: - Vai demorar, sim. Então pede para alguém da família dele ligar e passar os dados dele completos, porque precisa do nome completo dele!

S: - Porque quem está telefonando é a presidente da associação de moradores.

A: - Então, preciso do nome dele completo.

$\mathrm{S}:-\mathrm{O}$ nome dele completo?

A: $-\dot{E}$ !

S: - Só o nome?

A: $-\dot{E}$ !

S: - Então ele vai ver se pega o nome completo dele. Aí, eu ligo depois.

A: - Está ok!

[Alguns minutos depois]

A: - Central de ambulância, bom dia!

S: - É, bom dia! Acabei de ligar aí e o moço pediu o nome do rapaz.

A:- Certo. Qual é o nome dele? Pode falar!

S: - É Cirço Pedro da Silva.

A:- Como? Cirço?

S: -É Cícero Pedro da Silva.

A: - E não tem ninguém para vir com ele, senhora?

S: - Olha, não posso explicar para o senhor, porque eu sou a presidente da associação de moradores.

A: - Mas ele não tem família, senhora?

S: - Ah! Ele mora com a parente dele, mas o marido dela está trabalhando e ela têm bastante criança, não pode estar acompanhando ele!

A:-Mas sabe qual é o problema? O problema é o seguinte, que vem uma pessoa desinformada até o hospital, e aí ele vai ficar lá no banco, minha senhora, o problema é esse!

S: - Ele mesmo está pedindo para ir. Mas é ele mesmo que pediu para chamar a ambulância, porque ele quer ir. Então é uma oportunidade de estar tirando uma pessoa dessa droga, desse vício.

A: Certo! Ele usa...

S: - Se a pessoa está aceitando ir, eu acho que é uma boa idéia!

A:- Ele está usando muita droga?

S: - Não! É pinga, bebida!

A:-É alcoólatra.

S: - É bebida, certo?

A: - Bom, a gente vai fazer o transporte, está bom?

S: - Vai demorar?

A: - Vai demorar sim, uns 20 minutos.

$\mathrm{S}:-$ Uns 20 minutos?

A: - Isso! 
S: - Então, tem alguém aguardando aqui.

A: - Está ok então, senhora!

$S:-E$ faça o favor, porque ele está querendo ir, acho melhor a gente ajudar.

A: - Está bom.

S: - Eu acho.

A:-Está jóia!

S: - Obrigada!

A: - De nada, tchau!

$(\mathrm{A}=$ Atendente $; \mathrm{S}=$ solicitante $)$

Ex:มIP1.05:

A: - O que é que está acontecendo aí?

S: - É ele está com um problema na costa, está doendo...

A:- Está com dores nas costas? E não sabe porque está sentindo essa dor? Tem algum problema de coluna ou não?

S: - Deve ter, viu! Porque diz que dói!

A: - É a primeira vez que dá isso nele ou não?

S:-Hein?

A : - Já teve outras vezes?

S: - Já teve mais fraco, dessa vez está mais forte.

A: - Ele está andando ou não?

S:- Está acamado.

A: - Mas ele anda ou não?

S:-Ele anda, mas..

A: - É pessoa de idade?

$\mathrm{S}:-\dot{\mathrm{E}}$.

A: - O nome dele?

S:-- Cássio Aparecido Custódio

A: - Cássio Aparecido Custódio... Quem é essa pessoa que vai vir com ele?

S: - Sou eu, Joaquim.

A:- Joaquim do quê?

S: - da Silva.

A:-Que rua que é?

S:-Rua João Batista... Terezinha Ferreira... Coloca 'em cima'.

A: - Que número?

S: -189 .

A: - Dentro da favela?

S: - É pertinho da Nova Esperança. 
A: - E o senhor vai ficar aí, esperando na parte de cima aí?

S: - Isso.

A: - E a rua é asfaltada?

S: $-\dot{E}$.

A: - Então o senhor aguarda aí, viu!

S: - Está ok, então! Obrigado!

A: - De nada.

( $\mathrm{A}=$ Atendente $; \mathrm{S}=$ solicitante)

EXEMPI0 6:

A: - Central de Ambulância, boa tarde!

S: - Boa tarde! Eu moro na rua Santa Helena, 149, e tem um senhor caído aqui, perto da minha casa, que eu acabei de chegar. E estou ligando do orelhão porque não tenho telefone. Uma vez eu liguei, e não sei se foi para você, e vieram recolher uma pessoa. Eu não sei o que está acontecendo com ele, mas ele não está sangrando e eu queria saber o que é que eu faço?

A: - Quem está falando?

S:-Adriane.

A: - Olha, Adriane, é o seguinte. Você precisa saber se a pessoa está passando mal, se ele está conversando.

S: - Olha, eu não sei de nada, só está caído no chão, não sei se está desmaiado, se está bêbado, ou se está dormindo. Não sei, acabei de chegar!

A: - Não tem como você ver lá o que está acontecendo?

S: - Eu cheguei perto, mas eu não vou mexer. Eu não tenho uma luva, não tenho nada, não sei... de repente a pessoa é agressiva ou não, e se está viva. Eu não vou mexer!

A: - Olha minha senhora, aqui no momento eu estou sem ambulância nenhuma. O que eu posso fazer, é anotar e aguardar. Eu precisava saber se a pessoa está conversando, ver se ele consegue falar ou não.

$\mathrm{S}$ :-Conversar, não está conversando, não parece morto, mas também não abre os olhos. A gente passa perto dele, fala com ele, só que ele não responde nada, mas está respirando.

A: - Tem mais alguém com a senhora aí na rua que pode mexer com ele para ver se ele responde.

$\mathrm{S}$ : - Não, ninguém, ninguém quer ver.

A: - O que eu posso fazer aqui no momento, é anotar e aguardar.

$\mathrm{S}$ : - Faz essa gentileza, faz esse favor para mim!

A: - Como é o seu nome completo?

S: - Adriane... Agora eu não sei se na hora que vocês chegarem, se ele vai estar aqui ainda. 
A: - Então, senhora, por isso é que tem que ver se ele está passando mal e se ele quer ir para o hospital. Vai que manda uma ambulância aí, e ele não quer vir!

S: - É! Então deixa, porque eu não vou poder mexer, eu estou muito receosa. Posso até ajudar, mas mexer não.

A: - Tudo bem senhora, mas não tem como alguém fazer isso pela senhora?

S: - Você não sabe se tem alguma outra entidade da prefeitura que possa fazer isso por mim?

A: - Não. É o seguinte: a Central de Ambulância é urgência e emergência. A gente pede para o solicitante onde está o paciente e ver se ele quer vir, ver se ele não está passando mal. Se estiver passando mal, eu mando a ambulância.

S: - Mas se é uma entidade da prefeitura que dá assistência para as pessoas que ficam jogadas aqui na rua?

A: - Aquele lá é o Bem-Estar Social da prefeitura.

$\mathrm{S}:-\mathrm{Se}$ eu falar com eles, será que eles vêm buscar?

A: - Então, teria que ver primeiro se ele está passando mal, se quer vir para o hospital. Agora, se ele não estiver e se for um caso de levar para o albergue ou para o Funabes, aí seria com eles.

S: - Então eu vou tentar verificar isso, moço.

A: - Mas qual é o endereço que ele está?

S:-Avenida Santa Helena, 149, está aqui na calçada.

A: - Avenida Santa Helena, 149.

$\mathrm{S}$ : - Eu sou manicura e trabalho aqui na frente do orelhão.

A:-Adriane do quê?

S:-Adriane Trindade.

A: - A senhora não quer ver tudo certinho?

S:- Está bem. Qualquer coisa eu volto a te ligar. Agora vai que eu tento... Mas se eu não tiver coragem, vai ficar lá... Vai fazer o que aí... Eu ligo para a Funabes.

A:-Qualquer coisa, pede para a gente ir no local. Vê se ele está passando mal e vê se ele quer vir para o hospital. Ai, eu mando a ambulância.

S: - Mas eu acho que ele não vai responder sinceramente... Mas em todo caso...

A: - Olha, faz o seguinte. Vê se tem alguém nesse bar, vê se tem alguma pessoa que pode ir lá mexer, vê se ele quer vir, vê se ele está passando mal. E se ele estiver passando mal, eu mando a ambulância. E a senhora me dá o retorno.

S: - Está bom, obrigada.

A: - De nada!

$(\mathrm{A}=$ Atendente $; \mathrm{S}=$ solicitante $)$

OBS: os nomes aqui utilizados são fictícios.

Essas conversas telefônicas mostram que, tanto para os atendentes quanto para os médicos e as recepcionistas do pronto-socorro, o tempo da manifestação do(s) sintoma(s) entra como um dado significativo na avaliação de urgência: "está com dores 
desde que horas?"; "ele está com falta de ar há quanto tempo?"; "está com esse problema há quanto tempo?"; "quando que começou?"; "ele tem sempre?"; "é a primeira vez?". Um problema encarado a priori como sério (desmaio, membro quebrado, febre alta, dores no peito) tende a ser considerado menos grave e urgente quando não acabou de surgir, ${ }^{8}$ sempre conforme o mesmo raciocínio: já que esperou até agora, pode esperar "mais um pouco".

Essas ligações também indicam a dificuldade de os atendentes obterem as informações, mesmo que mínimas, que precisam para avaliar o problema de saúde e mandar uma ambulância ao local. Raramente o solicitante é o paciente ou mesmo alguém de sua família. É um vizinho, ou ainda um desconhecido, que sabe pouco ou nada da pessoa para quem chama: nem de sua situação habitual de saúde - se está sofrendo de uma doença, seguindo um tratamento -, nem do problema que motiva a chamada de uma ambulância.

Várias razões ajudam a entender o porquê. Quem liga para a Central muitas vezes tem um telefone em casa: simples morador, dono de loja ou de bar, alguém chega de repente avisando-o que é para ligar urgente para a Central e vai embora sem deixar nenhuma outra informação. $\mathrm{O}$ mesmo acontece com o solicitante que liga de um orelhão: os familiares (ou conhecidos) do doente ou do acidentado, naquela hora, muito preocupados e nervosos, pedem que ele chame o socorro; ou ele mesmo, participando da cena ou passando por lá, toma a iniciativa de chamar a Central. Assim, muitas vezes quando liga, não só ignora em grande parte o que aconteceu - "caiu", "está com dor", "está desmaiado"-, mas nem viu a pessoa para quem está solicitando a ajuda. Não sabe seu nome, apenas a conhece pelo apelido ou nem isso: "a gente chama ele de..."; "é um velho que mora do lado"; "é um moço que trabalha na construção do lado". Também não conhece o endereço exato:"

Ás vezes tem pessoas que ligam aqui apavoradas, eu pergunto para a pessoa, 'eu sou o vizinho, não sei te responder o que está acontecendo'. Então, nesses casos, a gente tenta, da pessoa que é a vizinha, tenta... A pessoa tenta responder melhor o que está acontecendo com a pessoa, lá, na residência. Quando não tem jeito, eu falo, 'tudo bem senhor', eu anoto o endereço certinho, o nome do vizinho, às vezes, o vizinho não sabe do nome completo do seu vizinho, não sabe nem o que está acontecendo com ele. Só falou com um parente lá na casa dele. pediu para socorro... então, às vezes, eu anoto e mando a ambulância. Mas antigamente, quando não tinha rádio, ai ficava dificil. Mas como tem rádio agora, o motorista chegando no local, às vezes, eu pergunto para o motorista o que está acontecendo realmente. 'Será que é aquilo mesmo que estava acontecendo no telefone?'. Eu tento fazer o máximo para uma pessoa me responder realmente o que aconteceu... o tipo de caso clínico que ela tem ou o caso mais grave que aconteceu com ela. Agora quando é um parente, ai fica mais fácil, posso perguntar o que está acontecendo. Ai, a pessoa sabe te responder. A coisa mais dificil é quando é vizinho. (Atendente 1)

Pior ainda para os atendentes são as pessoas que solicitam uma ajuda para desconhecidos que descrevem, geralmente, como estando "deitados ("desmaiados", "caídos") na rua" e com quem não ousam entrar em contato (com a fala ou com o toque). 
Essas chamadas são numerosas, e o Exemplo 6 é representativo do comportamento comum dos solicitantes nesse tipo de situação:

Casos que eu pego mais, também, são os de alcoolizados que caem na rua. Às vezes eles falam, 'ah, está desmaiado!', 'bebeu bastante aqui, encheu a cara, está desmaiado'. Tento tirar mais do solicitante, se ele está meio desmaiado, se faz tempo que ele está caído. Porque, às vezes, a pessoa passa na rua, o primeiro passa, vê, 'ah, deixa lá, deve estar dormindo!', então não tem aquela solidariedade, vontade de ajudar a pessoa. E, às vezes, quando a outra passa, 'ah, não, vou ajudar, vou ligar!'. Ai você pergunta: 'você conhece?', 'ah, não, é um andarilho, anda na rua, não sei quem que é!'. 'O senhor sabe mais ou menos desde que horas ele está caído?'. 'Não, passei agora, estou vendo agora, então não sei desde que horas ele está caído lá'. Então eu pergunto para a pessoa: 'não tem condição de você chamar ela, para ver se ela está dormindo, ver se ela está descansando?'. Às vezes ela bebeu um pouquinho só, então deitou para dormir. 'Ah, moço! Estou com medo de chegar perto'. Isso que fica para a gente. Então você não sabe se está realmente desmaiado, se está em coma, se está apenas descansando. (Atendente 1)

Quando os solicitantes são familiares, os atendentes obtêm geralmente os dados dos quais precisam: endereço, identidade, problema do paciente, sua situação de saúde e histórico, tipos de remédios que eventualmente toma etc. Mesmo assim, não é sempre simples e nem rápido. Sendo os solicitantes emocionalmente envolvidos na situação, torna-se difícil conseguir deles a calma necessária para a obtenção das informações. Aflitos, pedem socorro de maneira reiterada sem responder às perguntas do atendente, repetindo sem parar as mesmas frases desesperadas como "vai morrer, venha pelo amor de Deus!"; "faça alguma coisa, que ele vai morrer. Ah, meu Deus!".

Além do mais, os familiares nem sempre revelam o verdadeiro laço que os une ao paciente: querendo ocultar sua verdadeira identidade, escondem-se atrás da figura de um vizinho ou de um conhecido hipotético. São pessoas que não querem que seu parente saiba de sua ligação ao 192, geralmente para não sofrer represálias quando este voltar. Acontece em famílias que querem se livrar temporariamente de um dos seus membros cuja presença e/ou comportamento perturbam ou ameaçam seriamente a vida dos outros: pode ser o filho que se droga; o marido que bebe; a filha que, por ter problemas psiquiátricos sérios, exige muita atenção; o sogro cujo estado de saúde necessita muitos cuidados e gastos, para citar alguns exemplos correntes.

Importa ressaltar que todos os solicitantes têm dificuldade de descrever o que está acontecendo com a pessoa para quem pedem a intervenção do 192; qualquer seja a natureza de seu laço com ela. Suas respostas são breves, suas descrições gerais e sumárias. "Tento tirar [os dados] do solicitante", dizem os atendentes que têm de insistir. A pobreza e a limitação das falas (em termos de vocabulário e de expressão) na descrição dos sintomas, das sensações, também foram apontadas nas conversas entre os usuários e as recepcionistas do pronto-socorro. 


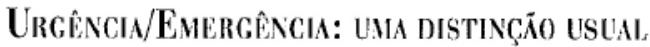

Os atendentes usam espontaneamente os termos 'urgência' e 'emergência', mas não discorrem sobre a distinção a ser feita entre as duas, nem sobre sua necessidade. Designam por 'urgência' os casos que, ao seu ver, 'podem esperar' e por 'emergência', os que consideram muito urgentes por serem graves (virem a se tornar se não forem atendidos com rapidez). Dito isto, a observação da rotina do 192 acaba revelando que, fora os casos severos que fazem entrar na categoria das ditas 'emergências', os atendentes consideram 'urgências' todos os problemas para os quais mandam uma ambulância, mesmo se não os acham graves, mas até corriqueiros:

Tudo que sai daqui, essas chamadas, para nós é uma urgência. A partir do momento que a ambulância chega no local, ela vai constatar se é uma urgência ou emergência. Ai, no caso, é quem está no local que comprova no local. Para mim, tudo é uma urgência. A partir do momento que sai daqui, é uma urgência. (...) Pelo que a pessoa me liga e fala, casos que você sabe que é urgente, o veiculo tem que sair mesmo, coisas assim graves, tipo enfarte, tipo parada cardiaca, hemorragia, coisas assim, que levam risco de vida da pessoa. Então, aí você manda assim rapidinho. Mas tudo é uma urgência! Uma vez lá é que a pessoa vai constatar se é emergência ou urgência. (...) Emergência mesmo, acho que são uns $30 \%$. O resto são coisas corriqueiras, bêbados ou dor de cabeça. Bêbados é direto. (Atendente 2)

Emergência para mim, é enfarte, quando a pessoa já está ou no principio de enfarte oujá está num estágio mais avançado. Ela está com cianótica, roxeando, ai é parte de emergência. Ai, na hora. Mando [a ambulância] na hora. E ai, enquanto eu mando a ambulância, a pessoa vai me dando os dados, ai vou anotando o resto. Quando a gestante também já está na parte... guase... dando a luz à criança, para mim já é uma emergência também. Todo caso grave mesmo que você vê por telefone com a pessoa, a pessoa conversando com você, vê que ela está assim apavorada, desesperada, você vê que é uma emergência, você manda na hora. Para mim, são uma emergência esses casos. Agora, urgência, urgência é mais assim... não é tão grave, dá para aguardar um pouco ainda, esperar a ambulância chegar, ou senão passar para o motorista do trânsito... Uma cólica de rim pode ser uma emergência quando a pessoa está, nâo está agïentando mais, quando já está desmaiando de dor. Ai, pode ser uma emergência também. Agora, uma cólica de rim que dá para agüentar mais que uma meiahora, já para mim, já é uma urgência. Emergência é mais aquele estado grave mesmo, que não tem... que a urgência não, a urgência é mais como... começou agora ou dá para agüentar mais um pouco, ai já é uma urgência (...) O certo disso daqui [a Central], era só emergência mesmo, só emergência... parto... só emergência. Não pegar esses casinhos de posto de saúde que não funciona. Eu peguei agora um posto de saúde aqui, do São Judas, que vai ter médico só às cinco da tarde. E a criança está com bronquite, eles não fazem inalação sem receita médica. Então fica dificil para a gente trabalhar aqui. A maioria dos casos clínicos que você pega é dor de cabę̧a, diarréia, vômito... Nesses casos, não precisa nem vir de ambulância, tinha que ir no posto de saúde, o médico consultar e mandar para a casa. Posto de saúde de Marília não funciona, então 
não tem como você fazer emergência com isso daqui. Às vezes, aparece uma emergência, mas às vezes não... às vezes não é nada. Emergência mesmo, depende, emergência, emergência, uns $10 \%$. O que dá mais é gestante, $50 \%$, metade, o que pego mais mesmo é gestante. É porque o hospital não tem leito, eles mandam embora, chegam em casa, a pessoa passa mal. (Atendente 1)

\section{Leque dos InfortúNIOS: AS URGÊNCLAS do 192}

Os discursos dos atendentes traduzem uma realidade: a Central atende numerosos casos que não têm muito a ver com sua função declarada, que é prestar socorro, por meio de suas ambulâncias e motoristas, a pessoas cujo estado de saúde justifica. Seus veículos servem para o transporte de muitos usuários que, se não fosse sua situação não tanto de saúde mas econômica - não recorreriam a eles. Da mesma maneira, se várias instituições - postos de saúde, serviço social, hospital público, entre outros cumprissem com eficiência suas funções declaradas, muitos dos pedidos recebidos pela Central deixariam de existir.

Os próprios atendentes da Central de chamadas dos bombeiros repassam para a Central de Ambulâncias os pedidos de ajuda relativos a 'casos clínicos' que, no seu ver, não exigem a intervenção do Resgate por não se tratarem de emergências. O 193 atua sobretudo em acidentes (de trânsito), e acabam caindo no 192 todas as outras solicitações que dizem respeito à esfera ampla dos problemas de saúde, muitas vezes entrelaçados a problemas e dificuldades de natureza social.

Da mesma maneira, a Central da Polícia, o 190, repassa para a Central de Ambulâncias, todas as chamadas relativas a situações de violência que envolvem pacientes ditos 'alcoolizados', 'drogados' e 'psiquiátricos'. Nesses casos, o 192 há de atuar primeiro no lugar, isto é, um de seus motoristas, às vezes acompanhado pelo chefe da Central. ${ }^{10} \mathrm{~A}$ polícia intervém em um segundo momento, se o motorista ligar pedindo sua ajuda. ${ }^{11}$ Esse esquema visa a proteger a polícia, cuja responsabilidade seria implicada se o paciente, indo com ela ao pronto-socorro, se machucasse durante seu transporte. Por isso, é levado de ambulância.

À diferença de seus colegas do 193 e do 190, os atendentes do 192 não têm como se livrar dos pedidos de ajuda relativos a problemas de saúde, que fogem de sua esfera declarada de competência (atender às urgências e às emergências), encaminhando-os para outros profissionais, ${ }^{12}$ pois não existe outra instância suscetivel de oferecer ou negar um atendimento, isto é, de tomar a decisão e de responder por ela. E como os atendentes da Central de Ambulâncias estão, ao mesmo tempo, preocupadíssimos com a implicação de sua responsabilidade nas decisões tomadas, e inseguros na triagem pela qual não se sentem muito qualificados, preferem atender aos pedidos mandando uma ambulância, do que arcar com as conseqüências de um possível erro. Temem que os pacientes ou sua familia entrem com processo por omissão de socorro e, para justificar sua postura, citam espontaneamente histórias de pessoas que, não atendidas porque seu caso não foi levado a sério, morreram, especialmente alcoólatras caídos na rua: 
Na divida, eu mando [a ambulância] do mesmo jeito. Pode estar dormindo, pode estar desmaiado... Porque se acontecer alguma coisa, quem tem que... a culpa vai vir do triador. Nunca se sabe. Igual esse paciente, ele é psiquiátrico, quer dizer, ele era..., ele tomava Aquineton, Aldose, aqueles remédios fortes e ele bebia por cima. E ele ia direto para o hospital, a gente pegava ele por dia... acho que eu pegava quatro vezes por dia. O médico vai lá, tenta segurar a pessoa, tipo... vai lá [para o pronto-socorro], vai embora, toma de novo. Então, esse paciente deu o maior... Porque ele estava caido de manhã na Vila Real. a gente foi buscar ele, ai levamos para o hospital. Só que acabou de sair do hospital, já vai andar para a rua e bebe de novo... pede esmola para as pessoas, vai beber de novo. Ele caiu mais uma vez, os colegas de bar não prestaram atenção, não chamaram a ambulância, ficou horas assim, e quando finalmente a ambulância chegou, estava morto desde várias horas. Os colegas disseram que tinham chamado a ambulância desde o início mas que não veio, o que é falso. (Atendente 1)

\section{E, mais adiante:}

Igual o tal do Resgate lá. Morreu um rapaz lá na... Salgueiro, a familia está.. Porque disse [o triador do Resgate quando ligou a familia] que não tinha ambulância dentro da hora, que ela estava em ocorrência, mas acho que não estava lá, acho que eles não mandaram porque acharam que não era grave. E a pessoa morreu... Eles estáo com medo mesmo de ter acontecido. (...) A família pode processar depois ou pedir indenização... Isso daqui [a triagem] é responsabilidade mesmo. (Atendente 1)

Afinal, o 192 aparenta-se mais a um serviço social, que, por oferecer atendimento à população $24 \mathrm{~h}$ por dia, acaba preenchendo, na precariedade, vácuos existentes no domínio da ajuda social, espaços deixados vazios por outros agentes e instituições de serviço público.

Pelo tipo de pedidos que recebe, pelas necessidades a ela expressas e pelas pessoas que solicitam suas ambulâncias, a Central reflete, ainda mais do que o prontosocorro, o desamparo e a carência de recursos das populações de baixa renda. Ela é o espelho do infortúnio social e individual, cujos problemas de saúde, entendidos no sentido estrito da saúde anatomofisiológica, só representam uma faceta. Na frente dessa demanda poliforma e dentro de um contexto de escassez, o 192 acaba atendendo quase todas as solicitações.

Como já foi indicado no Capítulo 3, a triagem na Central se realiza menos na seleção dos casos a serem atendidos do que no tempo que leva até ser prestado o atendimento: é mais pela inscrição, na dimensão do tempo, da ordem das prioridades, que ela se concretiza. 


\section{Notis}

1 Da mesma maneira que os seguranças, porteiros e recepcionistas do pronto-socorro.

2 Trata-se de pacientes cuja solicitação de ajuda foi feita por alguém da família, da vizinhança ou por um desconhecido, e que se recusam a ir para o pronto-socorro, uma vez a ambulância no lugar.

3 Do conjunto das ambulâncias, geralmente duas funcionam, às vezes só uma e nos melhores dias, três.

4 Como, por exemplo, retorno médico, transporte de um paciente ou/e do seu acompanhante do hospital para a casa. Como o Bem-Estar Social fecha às $17 \mathrm{~h}$ e que seu serviço de ambulância pára de funcionar às $19 \mathrm{~h}$, a partir desse horário e a noite toda, a Central de Ambulância passa a assumir a tarefa de transporte de pacientes (e acompanhantes). O mesmo acontece aos sábados e domingos, dias em que o BemEstar Social está fechado.

s Anotam esses elementos em uma ficha que o motorista pega no momento da saída, na qual ele inscreve seu nome, suas observações e assina uma vez de volta na Central onde a ficha fica arquivada.

6 A mesma constatação foi feita com os seguranças do pronto-socorro.

7 O paciente tem de ser acompanhado.

8 Exceto no caso de mulheres grávidas de 9 meses que se queixam de dores fortes há muitas horas.

9 Não conhece o nome da rua, ou o número, e indica um edifício que está do lado, um ponto que, para quem é do bairro, constitui uma referência visual.

10 Acontece quando a situação, tal como foi descrita no telefone, deixa supor que a intervenção de um motorista só não será suficiente (conter uma pessoa violenta e amarrá-la na maca para efetuar seu transporte até o pronto-socorro, por exemplo).

"I O documentário etnográfico Urgences (Giglio-Jacquemot, 2002) mostra esse procedimento em ação.

12 Como, por exemplo, na França, onde os atendentes das centrais de chamadas do Serviço Público de Ajuda Médica de Urgência (Samu-Centre 15) podem pedir, por exemplo, ao solicitante para ligar para médicos de plantão da cidade que atendem o paciente em seu domicílio, quando estimam que o caso não justifica sua intervenção. 


\section{7 \\ "Agora Não Tem Mais Condições,
Eu Não Agüento Mais!":
a perspectiva dos usuários}

E os usuários do sistema de atendimento às urgências e emergências? Será que para eles 'tudo é urgente', a menor 'febrezinha' ou 'dorzinha de cabeça', como costumam reclamar os diversos profissionais que, com ou sem formação médica, atuam na triagem das urgências?

As observações de campo mostram que, para apreender o que é urgente para eles, é preciso primeiro separar duas coisas que, por serem muitas vezes confundidas, desembocam nos julgamentos emitidos pelos agentes do sistema sobre o mau entendimento que os usuários têm do que é urgente no domínio da saúde. Faz-se necessário distinguir suas representações da urgência da utilização que fazem do sistema de atendimento às urgências. De um lado, temos uma percepção, do outro, o uso de um recurso. $O$ entendimento da primeira não se deixa necessariamente deduzir do segundo, conforme um raciocínio que é muito comum nos agentes da triagem.

Por exemplo, como é comum mulheres dos meios populares levarem suas crianças pequenas com febre, mesmo que pouco elevada, para o pronto-socorro infantil, infere-se que essas mães consideram qualquer 'febrezinha' uma urgência. Essa conclusão é equivocada, pois o raciocínio que a sustenta parte do pressuposto de que os usuários recorrem ao sistema de atendimento para o que acham 'urgente', como se suas motivações correspondessem obviamente às funções explícitas desse sistema. Daí presume-se que se não fossem tão ignorantes fariam um uso mais adequado do prontosocorro e da ajuda móvel, e defende-se a idéía de que campanhas de informação ao público ou programas de educação em saúde constituem a resposta apropriada para reverter a situação.

Ora não é tão simples. A realidade dos comportamentos é a resultante da combinação de lógicas múltiplas, e se os usuários recorrem ao pronto-socorro para problemas ou situações de saúde que, de fato, acham urgentes, também o procuram para problemas que, mesmo para eles, não apresentam um caráter de urgência. Entretanto, nem por isso, deixam de esperar a satisfação do que vieram buscar, a saber, um atendimento.

As conversas e reações dos pacientes a respeito da demora e da ordem de passagem na sala de espera desvendam a avaliação, em termos de urgência e gravidade, que fazem de seu próprio problema de saúde. Se eles, freqüentemente, resmungam e se 
queixam do tempo longo da espera, também manifestam comiseração pelos pacientes que, segundo eles, "não podem esperar" e admitem facilmente que passem na sua frente. Escuta-se, por exemplo, os comentários seguintes: "os médicos estão ocupados com uma urgência"; "chegou uma urgência, atrasou tudo"; "tem uma urgência dentro". Aliás, os pacientes resignam-se com a espera na medida em que consideram que, à diferença de outros, seu problema não é insuportável e nem coloca, de imediato, sua vida em perigo. $\mathrm{O}$ atendimento não precisa ser urgente, o que importa é ser atendido. Muitos depoimentos apontam para esse fato como, por exemplo, a fala de uma mulher que esperava um atendimento há mais de duas horas na sala de espera do prontosocorro infantil, para sua filha pequena que estava com febre:

\begin{abstract}
As vezes eu levo as crianças, às vezes é uma febre alta, às vezes é outra coisa, coisa que não acho assim urgente, se sabe que é um negócio assim controlável. Que dá para esperar um pouquinho. Então não estou agoniada que nem uma vez que quebrei o pé que eu vim para o PS. Ai, foi a única vez que eu fui assim pro PS, coisa que achei assim urgente. Que às vezes eu levo as crianças, vou no PS, mas não assim na urgência. Posso até esperar porque sei que vou ter um tratamento, não é? Então não é uma coisa assim... urgência... eu vou passar pelo PSe tal, no caso das crianças, mas o pé, não, o pé quebrado não dava para esperar.
\end{abstract}

As pessoas não recorrem sistematicamente à rede de atendimento às urgências para problemas de saúde que julgam urgentes. Esse fato merecia ser estabelecido antes de investigar o que é urgente para elas.

\title{
UrgênCIa/ EMERGênCIA: UMa distinģ̃̃o incomum
}

A palavra 'emergência' é pouco presente nas falas dos usuários, sendo as palavras 'urgência' e 'urgente' bem mais familiares. Para muitos, urgência e emergência "é a mesma coisa", eles não discriminam espontaneamente entre as duas. Quando usam a palavra 'emergência', geralmente é para designar as urgências que chegam ao prontosocorro de viatura de bombeiros, segundo uma assimilação forte da emergência com o Resgate. A essa também se sobrepõe outra, que, ligada à atuação visível dos bombeiros nos acidentes de trânsito, identifica 'caso muito sério' com 'intervenção do Resgate'. A emergência é, então, vista como uma urgência gravíssima, atendida rapidamente pelos bombeiros: "Quando vem de Resgate é emergência, se esperar morre" (trabalhadora doméstica, de uns 30 anos, que veio ao pronto-socorro de Rosália, de ambulância),"Quando você liga e é emergência, o Resgate vem em cinco minutos" (homem de uns 50 anos, que ligou para o 192 e conta que a ambulância demorou quatro horas até chegar).

Entretanto, as pessoas geralmente não estabelecem diferenças, em termos de graus de gravidade, entre urgência e emergência. Falam em urgência e quando querem significar que ela é grave dizem que "é muito urgente", que "é uma urgência mesmo". 


\section{Distanciar-se da Perspectiva Biomédica}

Para apreender o que os usuários consideram urgente no domínio da saúde, não se revela muito interessante nem pertinente ir à procura dos sinais fisicos que se constituiriam para eles em indícios de urgência, no intuito de repertoriá-los. Não é dessa maneira que se pode esperar alcançar sua percepção da urgência, e isso, por duas razões. Primeiro, porque esta não se limita, nem se deixa reduzir, a simples sinais de ordem orgânica/corporal. Veremos que a leitura de um sintoma e a percepção de um problema como sendo de urgência geralmente estão ligadas não estritamente ao sintoma ou problema em si, mas ao contexto geral no qual eles se manifestam. Segundo, porque seguir essa premissa consiste em adotar a categoria biomédica de 'urgência' seu conteúdo e seus critérios - como referência implícita na investigação do que é urgente para os usuários, o que representa uma abordagem muito equivocada do ponto de vista antropológico.

Para compreender o que constitui uma urgência para os usuários, é preciso se distanciar do que é 'uma urgência médica' para os profissionais da saúde e não abordála a priori como estes a definem e a identificam, a saber, como um estado ou uma situação de saúde que coloca a vida em risco, e cuja avaliação se dá graças à leitura de sinais que têm sua sede e sua expressão no corpo. Para os usuários, os sintomas corporais não são necessariamente mais pertinentes e mais decisivos do que outros indicadores de natureza diversa que não se restringem ao corpo. Não se deve ignorar que a urgência, enquanto categoria biomédica, está intimamente ligada a uma certa concepção da saúde entendida em sua dimensão anatomofisiológica. Pautadas nela, as urgências/emergências biomédicas são identificadas em alterações e problemas que dizem respeito estritamente a essa esfera.

Ora, os usuários não têm concepções da saúde que necessariamente coincidem com a da biomedicina, e inúmeras pesquisas em antropologia médica mostram, ao contrário, que "o contexto, seja das relações sociais, seja do ambiente natural, faz parte também de possíveis fontes de sinais a serem considerados na tentativa de identificar a doença, suas causas e seu significado" (Langdon, 2003: 97). Em conseqüência, as concepções e o vivido que os indivíduos têm do que ameaça perigosamente a sua saúde (ou a de outrem) podem vir a ser bem diferentes dos que decorrem da perspectiva biomédica.

\section{A Urgência: uma CONSTRUÇ̃̃o CONTEXTUAL}

Na sala de espera do pronto-socorro do Hospital das Clínicas, encontrei uma imensa quantidade de pessoas se queixando de uma variedade grande de sintomas, esperando um atendimento para um leque amplo de problemas que, tal como os formulavam, enquadravam-se dentro da saúde, entendida no seu sentido biomédico restrito: dor de cabeça, febre, fraqueza, pé torcido, cólica de rins, dor na coluna, na perna, tosse, falta de ar, tremedeira etc... Conversando ou caladas, esperavam a sua vez. Muitas não 
me pareciam estar ruins e a necessidade por elas manifestadas de um atendimento no pronto-socorro não ficava, de início, muito compreensível, sobretudo quando relacionada às suas desgastantes implicações: horas e horas de espera, perda de um dia de trabalho, obrigação de arrumar um esquema para a guarda das crianças deixadas em casa etc. Já me parecia muito mais óbvia a necessidade no caso das pessoas que expressavam muita dor ou que apresentavam problemas impressionantes.

Só entendi melhor quando o trabalho de campo se deslocou do pronto-socorro para a central de chamadas do 192, e que comecei a sair de ambulância em busca do atendimento solicitado. Porque então tive acesso a elementos de compreensão impossiveis de serem conseguidos a partir do pronto-socorro: com os motoristas, fui até onde moram os pacientes, descobri seus bairros, entrei em suas casas, vi e conheci os pacientes no meio de seus familiares, percebendo assim um pouco das relações existentes entre eles e interagindo também com todos. Em outros termos, recolhi dados relativos ao contexto no qual estão inseridos o paciente e seu problema, considerado e apresentado, por ele e/ou os seus familiares, como urgente. A partir da escuta, observação e vivência, compreendi que é a situação na qual se manifestam que, muitas vezes, confere a um sintoma - um estado de saúde - seu caráter urgente e, isso, à medida que eles também interferem e mexem com toda a situação. Assim, passei a entender como um problema sem caráter de gravidade para quem desconhece a situação pode ser lido como preocupante por quem está dentro dela; essa atribuição de gravidade só adquire sentido no seu contexto.

Para exemplificar, tomemos o caso de uma mulher idosa cuja filha ligou para a Central dizendo que sua mãe sofria de tuberculose, não parava de tossir e estava muito fraca. Depois da chegada da ambulância, deu para entender que a paciente, que de fato tossia muito e forte, morava com sua filha, genro e os três netos, e que, sendo a casa pequena, ela dormia no sofá da sala. As falas do casal revelaram que a mãe tossia, sobretudo à noite, e que seus acessos de tosse perturbavam o sono de toda a família, acordando as crianças e, príncipalmente, o marido que tinha de "levantar todo dia às $5 \mathrm{~h}$ da manhã" para trabalhar e acabava passando noites em claro. Dava para perceber, nas entrelinhas, que essa situação, que durava há dias, tinha-se tornado intolerável.

A tosse da mãe tinha acabado de criar uma situação de urgência: estava colocando em risco a sobrevivência e o equilíbrio dessa família pobre que dependia, em grande parte, da condição de trabalho do pai. Suportada por dias e noites sem sono, chegou a ser percebida como um problema grave: não só porque afetava a mãe, mas porque prejudicava fisica e moralmente toda a família; não em si, enquanto sintoma individualizado e isolado, mas enquanto manifestação criadora de uma situação que punha em perigo a vida da família. O problema da mãe constituía-se num problema para todos, urgente de ser resolvido. Para esse casal que queria, a todo custo, a internação da paciente no hospital, a solução passava aparentemente pelo afastamento imediato da mãe, já que os remédios (uma sacola plástica cheia) não tinham melhorado a tosse, apesar de "custarem muito caro".

É assim que uma tosse antiga e forte pode vir a ser considerada uma urgência. Dentro do pronto-socorro, separada de seu contexto, é pouco provável que ela seja 
vista dessa maneira.' Os médicos podem até pensar que, sendo antiga, ela não apresenta nenhum caráter de urgência e talvez façam a sempiterna pergunta: "mas por que a paciente não veio antes?". Da mesma maneira, num outro contexto, num outro momento (no início, por exemplo), numa outra família (menos pobre, com casa maior, quartos fechados), essa tosse pode não vir a se tornar urgente. Mas dentro de seu contexto, ela chegou a representar um problema muito sério. O conhecimento do contexto é fundamental para entender as urgências dos usuários. É a razão pela qual não se pode dizer que 'a tosse' - ou qualquer outro sintoma - é vista por eles como um sinal de urgência. Seria uma generalização não só abusiva, mas errada, tendo em vista que apaga a importância do contexto na atribuição do caráter de urgência.

Aliás, neste caso, como em numerosos outros, não é tanto o sintoma assinalado que necessita de uma intervenção urgente, mas o contexto geral no qual se manifesta e que perturba: muitos sinais de urgência não se encontram inscritos no corpo do doente, mas fora dele, na situação que o envolve. No exemplo anteriormente citado, eles não são apenas a tosse da mãe, mas a falta de sono do marido e o risco de ele perder o trabalho, o perigo de a família ficar sem recursos, sem falar do cansaço e do nervosismo das crianças e da mulher, para citar somente os elementos ameaçadores que foi possível identificar durante a passada por essa casa. É a conjunção de todos os fatores que desemboca numa situação vivida como urgente e é ela que procura ser tratada com rapidez.

\section{A URGÊnCIA: UMA CONSTRUÇ̃̃o COLETIVA}

Se a percepção da urgência é, então, uma construção contextual que envolve sinais heterogêneos de perigo, ela também é uma construção profundamente coletiva da qual todos participam, isto é, não somente o doente, mas membros de sua família e até vizinhos. Aliás, nem sempre o paciente participa dessa construção, e os exemplos mais flagrantes de sua dimensão coletiva são certamente os dessas pessoas cujo estado de saúde é designado e apresentado por suas famílias/vizinhança como grave, mas que dizem estar bem e que não querem a ajuda de urgência e, ainda menos, de um atendimento. Quando os motoristas de ambulância chegam à casa desses pacientes, muitas vezes, os encontram em situações e num estado aparente que contrastam bastante com os da descrição dramática feita por telefone.

No exemplo anterior, é o casal que parece ter avaliado o problema da mãe e acionado o meio para tratá-lo. Não dá para saber se a mãe tomou parte dessa apreciação e associou-se à decisão, pois não abriu a boca em nenhum momento. De qualquer maneira, concordando ou não, ela se deixou tranqüilamente levar para o pronto-socorro. Agora, há numerosos casos em que a discordância é manifestada com força pelo paciente que se rebela e recusa abertamente a apreciação e a decisão impostas por seus familiares. Aí, a avaliação não é consensual e revela que atrás dela, atrás do pretenso problema de saúde que precisa ser atendido com urgência, outras coisas estão em jogo, outros perigos estão ameaçando. O que mais uma vez aponta para o caráter totalizante, 
e não restritamente médico, da percepção da urgência que encontra em riscos de várias ordens seus sinais de perigo.

No intuito de aprofundar essas colocações, vamos examinar o caso bem representativo ${ }^{2}$ de um homem de 56 anos, cuja mulher ligou para a Central do 192 dizendo que o marido era alcoólatra e a agredia, que no momento estava passando muito mal, que precisava ser tratado com urgência, pois bebia sem parar há alguns dias, apesar de o médico ter dito que não podia, "de jeito nenhum", por causa de uma cirurgia feita há alguns meses atrás. Expressando muita inquietação pelo estado de seu companheiro que, segundo ela, se encontrava muito ruim na cama no momento da ligação, ela pediu para a ambulância vir depressa.

Chegando lá, encontramos a mulher no portão de entrada da casa. Repetiu o que tinha dito por telefone e acrescentou outras queixas, enumeradas uma após a outra, numa logorréia irreprimível: seu marido bebia muito ("não sai do bar"), estava devendo três aluguéis, "água, luz, tudo", não queria trabalhar, mijava na cama, batia nela (já tinha feito um boletim de ocorrência na Delegacia da Mulher), tinha acabado de ameaçá-la fisicamente, falando o seguinte: "vou fechar a casa e vou te arrebentar". Enquanto falava, seu comportamento indicava que o marido não sabia da chamada: segurandonos no portão, o tempo de contar o que ele não deveria escutar, ela virava a cabeça de vez em quando para a casa, atenta e inquieta. Para pôr fim na fala da mulher, o motorista falou: "deixa eu conversar com ele" e fez um movimento para entrar. Ela o deixou passar, declarando que ela "não tinha mais condição" e que o proprietário, "Seu Manoel", ia mandá-los "embora da casa". O motorista disse-lhe que seu marido provavelmente não ia querer ir ao hospital e the perguntou se ela concordava com o procedimento aplicado neste casos, a saber: "chamamos a polícia, nós amarramos ele na maca e vamos até o hospital". A sua pergunta - "certo? posso fazer isso?" - a mulher deu uma resposta que manifestava claramente sua vontade: "Pode, claro, não posso ficar...". Indo à direção da casa, ela ainda falou que dormia no sofá da sala com duas facas de cozinha, pois seu marido tinha dito que ia esfaqueá-la durante o sono, o que sua vizinha confirmaria se estivesse presente. Em alguns minutos, então, o declarado grave problema de saúde do marido tinha passado ao segundo plano: quem precisava de ajuda era a mulher, quem estava em risco de vida era ela. Nas entrelinhas, seu discurso visava a convencer o motorista da realidade e da proximidade do perigo que a estava ameaçando, a saber: seu marido; se a ambulância não o levasse agora para o hospital, ela podia morrer, pois ele ia matá-la.

Entramos na sala da casinha miserável onde morava o casal. A mulher abriu a porta do quarto escuro no qual se encontrava seu marido, deitado na cama. Parecia estar dormindo e levou um susto quando nos viu. Colocando-se de lado, apoiado em seu braço, ele perguntou: "o que está acontecendo?". E, em seguida: "você é da onde?". O motorista, para quem estava olhando, respondeu: "somos do Hospital das Clínicas", e o homem imediatamente se rebelou: "não, não vou para lá, não, não preciso ir para lá, não. Estou bom, estou tranqüilo". O motorista procurou apaziguá-lo, tentando convencêlo de que ir para o hospital era bom para ele e que logo estaria de volta em casa: "Vai medir a pressão, o médico vai receitar um remédio para você, no caso de você ficar nervoso, essas coisas todas, aí a ambulância pega você e traz você de volta. 
Rapidinho!". "Não!", falou o homem. Neste momento, a mulher entrou na conversa, enfatizando o problema do marido e sua gravidade:

\begin{abstract}
Moço, moço! Ele fez uma operação, os médicos aqui não quis operar ele porque não tinha os aparelhos aqui... Precisou ir em São José do Rio Preto. Ele não pode beber, esse homem não pode beber. Ele operou em São José do Rio Preto. Esse homem morreu e viveu de novo, certo? Eu tenho tudo ai, guardado, eu tenho testemunhas!
\end{abstract}

O estado de saúde do homem tinha voltado ao primeiro plano. O motorista reforçou a fala da mulher, dizendo: "é perigoso, vai ter que fazer outra cirurgia, vamos lá, fazer um check-up geral e aí volta para cá, numa boa. (...) Você vai lá para dar uma geral, para ver, você não pode beber, está bebendo, pode prejudicar, você pode ter que fazer outra cirurgia futuramente". "Não, não preciso ir lá, não!", insistiu o homem. "Então pode deitar e ficar calmo", falou o motorista que saiu do quarto com a mulher desesperada: "eu chamo vocês de novo, pelo amor de Deus! Porque eu não posso. Eu fico pousando na casa dos outros... por causa...". O motorista saiu do quarto e, com um gesto firme da mão, indicou a saída para ela. Andando de volta para o portão, ele disse: "é o que falei para a senhora (...). Eu não posso pegar ele dentro da casa pela força e levar. Se a senhora permitir, eu vou chamar a polícia, pegamos ele, colocamos na maca...". "Tem que levar, sim!", disse ela chorando. "Então, deixa ele quietinho!". Fora da casa, o problema da saúde do marido ficou relegado, de novo, em segundo plano.

O motorista precisava telefonar para a polícia. Fomos juntos até um orelhão e, depois da ligação, voltamos para a frente da casa onde esperamos um bom tempo, na calçada, a chegada de um carro da polícia. Durante este tempo, a mulher continuou expondo suas recriminações. Não parava de falar, dando cada vez mais informações sobre o marido e seu comportamento, sobre ela e seus problemas por causa dele, sobre a vida que estavam levando juntos. De maneira desordenada, contou que ele a tinha espancado fazia 15 dias, que não sabia onde ele bebia, comentou que ele não tinha "precisão de estar atrasando o aluguel para Seu Manoel", falou que tinha "dez anos de prefeitura" e que estava "aposentado por causa dessa operação". Mas, acrescentou ela, "ele recebe dinheiro. Ele fala para mim que não recebe e vai pagar o bar. Está devendo três aluguéis para o homem. Eu não posso mais ficar nessas condições!". Ainda falou que "o pior é que ele não endireita, então tem que tomar uma solução", e, sem transição, apontou para seu estado de saúde, muito ruim por causa dele: "tomo cinco tipo de remédio: eu fiquei doente, eu tenho problema de cabeça por causa desse homem. (...) Eu tomo Diazepam, eu tomo Trepitanol, eu tomo um remédio para úlcera....". Foi neste momento que o marido apareceu na porta da casa. Estava saindo e se dirigindo em nossa direção, andando de maneira insegura. "Olha, ele, ele!", avisou a mulher que já tinha manifestado, várias vezes, seu receio de ele fugir antes da chegada da polícia. "Deixa ele sair. Depois nós vamos atrás dele, nós pegamos ele. Fique sossegada", respondeu o motorista com firmeza. O que veio a seguir foi inacreditável: o homem passou nos ignorando ao mesmo tempo que o motorista e a mulher desconheceram sua passagem. Só olharam para ele quando havia se afastado bastante. 
O marido foi embora enquanto ficamos na calçada, à espera da polícia. A muit:er continuou falando e fornecendo elementos que davam para entender sempre melhe: $:$ que, na situação presente, a tinha levado a solicitar a Central e a pedir não somen: : : atendimento urgente, mas também a internação de seu marido. "Ele fez cirurgia iz quê?", perguntou o motorista. "Ele fez o tal de neurismo que se diz...", respondeu ela. acrescentando: "Sabe, tinha aparelho, se não ele morria... Agora ele vai querer mé matar? (...) Estou avisando faz tempo, desde que a gente veio aqui: você não pode beber!. Já deu convulsão duas vezes, ele já quase morreu, eu que corro com esse homem..." “A convulsão foi provocada pela bebida?", inquiriu o motorista. Ela respondeu:

É, por causa da bebida. Já ficou internado na Santa Casa uma semana, ficou no Hospital das Clínicas, sabe. (...) Esse homem não pára de beber e fica me agredindo desse jeito. $O$ pior é o aluguel com o homem aqui. $O$ dinheiro da aposentadoria dele está para chegar e ele disse que vai pegar esse dinheiro e vai sumir no mundo, não vai pagar o homem aqui, o que que eu vou fazer? Não tenho casa própria ainda. Eu que tenho que pegar esse dinheiro. Fui lá no meu sogro antes de ontem, pousei nele ontem. Porque toda vez que vou lá, eu conto, eles perguntam, 'está cada vez pior', conto tudo que ele faz comigo aqui

Para resumir o fim desse caso, a polícia acabou chegando e, acompanhada pela ambulância (a mulher sentada na parte traseira), foi à procura do homem nas ruas da cidade e o encontrou num bar. "Não tem problema comigo", afirmou imediatamente ele para os policiais que foram até o balcão. "Vai lá, no hospital", respondeu um deles. "Para quê? Para que eu vou lá? Eu não vou, não!", reagiu o homem. Depois de conversas tensas centradas na necessidade de ele cuidar de seu problema de saúde - "é o que falei para você, vai passar por um médico, ele vai ver como está, depois volta para a casa", insistiu o motorista - ele acabou subindo na ambulância, na condição de não ser amarrado na maca. Os policiais foram embora, e a mulher foi levada ao pronto-socorro de carro particular por um conhecido do marido que, na lanchonete, tinha presenciado a cena toda.

\section{A Urcência: uma constelaç̃o de sinais de PERIGo}

O que leva a apreciar um problema de saúde urgente não são sinais que só dizem respeito a ele, mas sim a um conjunto de sinais de perigo que, por se juntarem todos ao mesmo tempo, configuram uma situação de alto risco que torna esse problema grave e urgente. No caso citado, os sinais de risco não são percebidos ou considerados pelo marido, mas pela mulher. São de várias ordens. No nível mais explícito do discurso, parece que o alcoolismo do homem e seu estado de saúde ruim a preocupam: "ele já quase morreu". O fato de ele estar alcoolizado o tempo todo - "ele bebe todo dia!"pode ter aumentado sua inquietação no momento. Mas, considerando-se somente esses problemas, não dá muito para entender por que vieram a se tornar tão urgentes na percepção da mulher, pois, não são novidade. Há os sinais ligados ao risco de agressão 
física. Mas, aí também, esse perigo faz parte do cotidiano da mulher já faz tempo. Entretanto, as ameaças de pancada e de morte recentemente proferidas pelo marido talvez tenham exacerbado seu temor. Da mesma forma, as dívidas do casal constituem um perigo sério, já que vivem numa condição miserável. Porém, também não são novidade: deu para saber que o casal está devendo, pelo menos, o pagamento de contas de luz, de água e três aluguéis. Mas aí o fato novo, o grande perigo ao qual o casal está agora exposto é a perda da moradia. Ele aterroriza a mulher: a questão dos aluguéis não pagos volta de maneira reiterada em sua fala e, entre todos os problemas que indica, é este que parece central para ela. O proprietário - o "Seu Manoel", ao qual ela sempre se refere e que passou em casa pouco tempo antes de ela chamar a Central - deve ter ameaçado o casal de expulsão: "Seu Manoel vai mandar nós embora de casa", "o pior é o aluguel com o homem aqui", "não vai pagar o homem aqui, o que é que eu vou fazer?".

Parece, então, que é o surgimento dessa ameaça iminente que passou a transformar o vivido de uma situação difícil no vivido de uma situação grave, porque além dos vários riscos que já pesam na existência dessa mulher, o que se delineia no horizonte imediato são a miséria absoluta, a degradação e a morte social, entre outras consequêencias terríveis. Sem casa, sem dinheiro, com um marido doente e alcoólatra, essa mulher vai para o 'fundo do poço'. Será que ela tem uma percepção errada da urgência quando avalia que os problemas de saúde do marido precisam ser tratados com urgência? Relacionados com os perigos aos quais expõem, é de convir que são muito preocupantes. $\mathrm{Se}$, nesse contexto muito problemático e precário, os donos da casinha tivessem continuado compreensivos, pode ser que o alcoolismo do marido, apesar de inquietante $\mathrm{e}$ assolador, não tivesse chegado a ser considerado pela mulher como necessitando uma intervenção tão imediata. Mas, uma vez que surgiu a ameaça séria de expulsão da casa, ele passou a se tornar um problema seríssimo.

Conhecendo alguns dos elementos de contexto que envolve o problema de saúde do marido dá, então, para entender porque está percebido como urgente e porque é tão importante para a solicitante seu marido ser rapidamente levado ao pronto-socorro e internado no hospital para fazer uma cura de desintoxicação. Porque assim, quem sabe, a saúde dele melhore, não beba mais ou beba menos, tenha mais dinheiro, fique mais fácil de conviver, não bata mais nela, não desapareça etc. Também, enquanto ele está internado no hospital, ela respira e se recupera um pouco, vive mais tranqüila. E, sobretudo, a pensão do marido estando "para chegar", é bem provável que, enquanto ele estiver preso no hospital, ela saque o dinheiro, pague uma parte dos aluguéis atrasados e tire assim de sua frente, por algum tempo, o grande perigo da perda da moradia.

Neste caso, como em muitos outros, os riscos e danos vividos como os mais graves não são os que ameaçam diretamente a saúde da pessoa para quem está explicitadamente solicitada a intervenção urgente, mas os que ela faz pesar nas existências das pessoas próximas (família, vizinhos). Afinal, é ela mesma que se constitui num perigo para os outros, para sua saúde ("eu fiquei doente, tenho problema de cabeça por causa desse homem", fala a mulher) e até para sua vida. Por isso, ela precisa ser tratada com urgência, isto é, antes de tudo, afastada da casa e mantida no hospital o maior tempo possivel: a ajuda pedida e oferecida diz menos respeito ao doente designado do que a seus familiares. 


\section{Os Urgentes 'Pequenos Problemas'}

É importante assinalar, também, a existência de um outro tipo de situação em que o problema de saúde, embora não sendo considerado pelos pacientes como uma ameaça séria para sua vida biológica representa, no entanto, para eles (e seus familiares) um perigo. É o caso desses aparentes 'pequenos problemas', que não são considerados urgentes pelos profissionais da saúde, e cujo pronto-socorro está repleto: são as dores de cabeça, cortes, sensações de fraqueza, tonturas, membros torcidos, dores na coluna, nas costas etc... Apesar de não pôr a vida das pessoas em risco, no sentido biomédico, eles a ameaçam e a dificultam seriamente. Existem outras mortes e outros sofrimentos a serem temidos do que os do corpo físico.

Para a empregada doméstica, a balconista, o pedreiro, o motorista, o peão, a mulher sozinha que tem vários filhos para criar, um pé torcido, tonturas, enxaquecas, dores nas costas, não são 'pequenos problemas'. Talvez o sejam no início de suas manifestações, mas com o tempo, vêm a se tornar seríssimos: alterando a capacidade no desempenho das atividades diárias, eles podem trazer enormes conseqüências, entre as quais, a perda do emprego. Nesse ponto, a percepção da urgência dos usuários entra em choque frontal com a dos profissionais da saúde. Com efeito, o papel do tempo na construção do que vem a ser considerado urgente pelos primeiros é muito diferente do que desempenha nas concepções biomédicas da urgência (normativas ou não). Foi demonstrado que, quanto mais um problema (um sintoma) é antigo, menos tende a ser considerado pelos médicos como urgente: é o caráter repentino de sua manifestação que aponta para seu possível caráter de urgência. Ora, na percepção dos usuários, o tempo geralmente trabalha no sentido exatamente contrário. É por sua persistência, através do tempo, que um problema (sintoma) vem a ser considerado urgente: em si, pois sua duração não habitual e o fracasso dos recursos terapêuticos usualmente utilizados acabam tornando-o muito anormal e preocupante; e no contexto onde se manifesta, pois sua permanência tem incidências cada vez mais negativas e pesadas sobre a vida. Uma cefaléia passageira, mesmo forte, pode não ser lida como um sinal de urgência. Mas uma que não passa ou volta sempre, desde dias, sim. É sua duração excepcional que alerta e que acaba tornando-a intolerável, urgente de ser tratada: por causa dos sintomas penosos, para se livrar da dor, das náuseas, da sensibilidade e irritabilidade extremas; por causa das perturbaç̃es que estes sintomas provocam nas relações e em todas as áreas da existência da pessoa.

Os 'pequenos problemas' levam os usuários a consultar no pronto-socorro porque atrapalham gravemente a vida cotidiana: no domínio social, familiar, conjugal, profissional, econômico, eles ameaçam piorar desequilibrios existentes ou ainda romper equilibrios, já muito frágeis, dificilmente conseguidos e mantidos por parte dos que recorrem à rede pública de atendimento às urgências/emergências, a saber, na sua maioria, pessoas das camadas socioeconômicas mais baixas. Devido à precariedade de seus meios e condições de existência, muitas delas já vivem 'normalmente' numa situação de urgência permanente e com poucas garantias contra as ameaças de toda ordem que potencialmente as cercam. Sobrevivem mais do que vivem, e sua sobrevivência depen- 
de fundamentalmente de seu estado de saúde, ou melhor, de estarem em condição de poder cumprir, fisica e mentalmente, as tarefas do dia-a-dia. Em um contexto geral de urgência e insegurança, muitos 'pequenos' problemas de saúde podem vir a se tornar grandes.

Os dados de campo mostram que não existe, enquanto tal, uma nosografia popular da urgência médica: ao contrário, assinalam a importância fundamental do contexto na atribuição do caráter urgente e o caráter, muitas vezes, pluridimensional do objeto desta atribuição. Entretanto, uma generalidade, nada surpreendente, pode ser estabelecida, no que diz respeito aos sintomas considerados urgentes pelos usuários, no domínio da saúde estritamente anatomofisiológica. Tudo que é vivido como colocando em risco a capacidade de trabalhar (trabalho doméstico ou remunerado), tudo que a altera, a diminui, a impossibilita, constitui-se num perigo grave, num problema urgente a ser tratado: uma enxaqueca rebelde como uma perna quebrada, uma sensação durável de fraqueza como uma paralisia repentina.

\section{A SaÚde AdinTte}

Nas urgências dos usuários, tudo gira em torno do problema de saúde sem que este seja necessariamente, no fundo, o verdadeiro problema. Contudo, é interessante notar que é sempre dele que explicitamente se trata e a propósito do qual se fala, e isso mesmo quando está manifestadamente ocupando um lugar secundário: é ele que está evidenciado pelos usuários em seus pedidos de atendimento, quer seja pelos atendentes das centrais, quer seja pelo pessoal que atua no pronto-socorro; é a ele que os atendentes e motoristas também dirigem suas falas e perguntas nas interações com os pacientes e solicitantes.

É como se todos os atores implicados fizessem de conta, tacitamente, de que se trata, somente, ou antes de tudo, de cuidar de urgências que dizem respeito à vida biológica e que, por isso, exigem uma atuação médica. Mesmo quando os solicitantes, uma vez conseguida a chegada da ambulância, expressam e mesclam, em um discurso muitas vezes confuso - à imagem da mulher de nosso exemplo - todas suas queixas e motivos médicos e extramédicos, os motoristas continuam imperturbáveis a focalizar suas falas sobre o declarado problema de saúde e sobre o doente para os quais foram chamados. Todos desempenham o papel esperado e, sobretudo, formalmente previsto pelo dispositivo de atendimento às urgências e emergências médicas, pelo qual trabalham ou ao qual apelam. Somente o paciente (ou a vitima) designado é que, às vezes, se rebela, recusando a etiqueta de doente sério que lhe é imposta: mesmo assim, é tratado como se precisasse de um atendimento médico e levado para o pronto-socorro. Quaisquer que sejam as diversas razões que podem explicar esse consenso de todos em torno do caráter médico das urgências atendidas, ${ }^{3}$ o fato é que ele abandona logicamente à biomedicina e aos seus representantes o tratamento de problemas para os quais estes não constituem necessariamente a resposta apropriada ou única, isto é, que não podem resolver (curar) ou mesmo melhorar. 


\section{Not'As}

1 Aliás, a tosse é citada com freqüência pelos triadores do sistema como o exemplo, por excelência, do não urgente.

2 Este caso, que foi filmado, está apresentado no documentário etnográfico "Urgences" (Giglio-Jacquemot, 2002).

3 Cuja investigação e discussão deixamos para um outro trabalho. 


\section{Considerações Finais}

No hospital, os médicos somente percebem e consideram um aspecto das urgências dos usuários: a parte anatomofisiológica que aponta para um problema de saúde que, para eles, muitas vezes não justifica o recurso ao pronto-socorro e que, de fato, destacado da situação que o envolve, e do vivido do paciente como de seus familiares, pode não se configurar como urgência biomédica. Da urgência, os profissionais da saúde têm uma concepção especializada, 'singularizante' e 'autonomizada' em relação às outras esferas da vida que não a biológica, o que não significa que suas apreciações/avaliações apenas estão informadas por critérios técnicos: colocamos em evidência elementos que, antes e fora de qualquer exame (clínico e/ou por mediações instrumentais), influenciam significativamente suas apreciaçōes e participam, de antemão, tanto à valorização ou desvalorização dos estados/problemas de saúde como urgentes ou emergentes quanto ao desencadeamento de comportamentos de maior ou menor mobilização e consideração em relação aos pacientes. Vimos que a importância desses elementos não é pequena: diversamente presentes, combinados e atuantes segundo os momentos e as situaçôes, eles afetam positivamente ou negativamente o atendimento e o tratamento dados aos pacientes. Eles abrangem tanto sinais manifestos quanto representações e valores, que, proprios do grupo profissional médico e/ou difundidos na sociedade global, guiam a leitura dos sinais e decidem do significado $a$ priori que lhes é atribuido.

Não insistimos sobre a avaliação moral dos pacientes pelos médicos, cuja influência sobre a ordem de prioridade e a qualidade do atendimento, o diagnóstico, o tratamento e a orientação final foi observada, por exemplo, por Roth (1972) em prontossocorros dos Estados Unidos. Entretanto, notamos a existência de julgamentos e comportamentos em relaçăo a certas categorias de pacientes - mulheres, 'alcoólatras', 'drogados', 'pacientes psiquiátricos' - que atestam sua adesão a preconceitos decorrentes de concepções culturais do valor social (também compartilhados por outros profissionais do pronto-socorro). É de se perguntar se a forte desconfiança e o desprezo dos médicos pelos pacientes ("são ignorantes", "fingem", "mentem" etc.) não estão ligados, em grande parte, a preconceitos sociais, visto que a clientela é composta em quase totalidade por pacientes de baixa renda, e que os raros pacientes que aparentam um bom ou alto nível social são geralmente atendidos com mais consideração e rapidez, tanto por eles quanto pelo resto do pessoal que atua no pronto-socorro.

Da urgência, os usuários têm uma concepção cujo caráter 'globalizante' contrasta bastante com a concepção biomédica, pois aquela reúne o que esta dissocia e concebe separadamente. As urgências vividas por esses leigos são configurações ameaçadoras, formadas de fenômenos e acontecimentos heterogêneos, que não têm 
todos uma ancoragem fisiológica, mas que têm todos em comum de ser considerados e vivenciados como riscos que põem a vida em perigo. Suas urgências indicam suas necessidades, mas, sobretudo, os transtornos e sofrimentos que pesam no seu inseguro viver e sobreviver.

Entre as duas concepções, a biomédica e a leiga, existem poucos pontos de encontro, a não ser o do corpo material, como sede da vida biológica, e o do espaço físico do pronto-socorro, justamente onde se manifesta, de maneira gritante, o grande mal-entendido que nasce da confrontação entre concepções pouco conciliáveis da urgência. $\mathrm{O}$ encontro se dá sem atrito quando os pacientes sofrem de um problema que apresenta características que vão ao encontro daquilo que os profissionais da saúde atribuem e reconhecem como "verdadeiras urgências (emergências)". Neste caso, as duas partes se mostram satisfeitas: os usuários porque são atendidos com rapidez e têm sua percepção e vivência da urgência reconhecidas; os médicos porque fazem o que corresponde à sua função declarada e às suas expectativas, a saber, atender urgências e emergências.

O exame da percepção que os usuários têm da urgência responde, indireta $\mathrm{e}$ parcialmente, à questão das motivações de seu recurso ao pronto-socorro; especialmente no que diz respeito ao menos imediatamente inteligível, a saber, os problemas de saúde que não apresentam, medicamente, nenhum perigo imediato. Vimos que, à imagem dos profissionais da saúde que os atendem, os usuários nem sempre acham seus problemas graves e urgentes. Nesses casos, o motivo do recurso é bem prático: no pronto-socorro, eles sabem que vão ser atendidos, pelo menos no mesmo dia, e que será de graça assim como todos os procedimentos médicos necessários. A espera longa e desgastante não os desencoraja: estão acostumados a enfrentar no dia-a-dia outras filas intermináveis, e seus depoimentos testemunham a dificuldade e os sacrifícios ainda maiores, para conseguir atendimento na rede básica de saúde, por sinal bastante desacreditada. Para eles, como para as populações pobres de muitos países, o pronto-socorro representa a porta de entrada no hospital, ou melhor, a porta do acesso aparentemente mais fácil, prático e crível aos cuidados de saúde.

Vimos também que os usuários recorrem à rede de atendimento às urgências e às emergências para problemas que, para eles, necessitam uma intervenção rápida. A compreensão de sua concepção totalizante da urgência pode ajudar a entender os motivos de sua "insubordinada exigência de um atendimento urgente" (Deslandes, 2002: 175). Ela esclarece o 'por quê' e o 'como' - em contextos dominados pela insegurança, dificuldade e sofrimento - um problema de saúde pode vir a ser vivenciado como urgente e passar a cristalizar todos os perigos. Atrás da máscara da saúde e da urgência biomédicas, demandas ocultas de proteção e socorro são expressas e dirigidas pela população a um dispositivo cuja capacidade de resolutividade dos intricados problemas que estão na raiz de suas urgências é limitada ou nula. Entretanto, os serviços que oferecem esse dispositivo representam ajuda, atendimento e abrigo preciosos no momento da manifesta necessidade.

Entre os problemas de saúde urgentes dos usuários, há os que o pessoal médico, assim como todos os agentes da triagem, não reconhecem como urgentes: são geralmente os famosos 'probleminhas' que, para os primeiros, não são os menos graves, mas que 
representam, para os outros, os exemplos por excelência, de um uso desvirtuado do pronto-socorro e da ajuda móvel de urgência. Há também os problemas que todos, leigos e especialistas, acham a priori urgentes: estes sâo, geralmente, os mais impressionantes e espetaculares, tanto em suas manifestações exteriores, inscritas no corpo fisicamente machucado por fora, quanto nas situações que os provocam (acidentes). Há, por fim, os problemas que os profissionais da saúde não julgam (possivelmente) urgentes, mas que outros agentes da triagem, não médicos, sim, e inversamente.

As apreciações e práticas das várias categorias de agentes envolvidos na triagem das urgências/emergências têm suas especificidades e dentro de cada categoria ainda existem variações de um indivíduo para o outro. Contudo, constatamos o papel crucial que desempenham os primeiros profissionais pelos quais passam os usuários, pois sua avaliação e decorrente categorização dos pacientes em urgentes e não urgentes tendem geralmente a ser aceitas pelos agentes encarregados das etapas ulteriores do atendimento. Essa realidade múltipla da urgência leva a situações inesperadas (para não dizer, absurdas) nas quais não são somente os leigos que têm suas apreciações recusadas pelos especialistas médicos, mas estes também que vêem suas avaliações rejeitadas por outros profissionais, não médicos, da urgência/emergência. É assim, por exemplo, o caso de uma médica urgentista, que, tendo quebrado a perna no banheiro de um apartamento em São Paulo onde se encontrava sozinha, teve seu pedido de socorro não atendido pelo Resgate sob a alegação de que seu problema não era uma emergência. Para o bombeiro que atendeu sua chamada, estava faltando uma fratura exposta que, segundo a análise da própria médica, teria configurado, sem dúvida, a existência de uma "verdadeira emergência".

A noção de urgência assim como sua percepção e seus sinais são plurais, e seu entendimento não pode ser isolado dos diversos contextos e atores que lhes conferem seu sentido. Profundamente polissêmica e ancorada na complexidade do social, a urgência dificilmente se deixa encerrar dentro dos limites biológicos nos quais as ciências médicas tentam legitimamente circunscrevê-la, diante de sua perspectiva e de seus objetivos. $\mathrm{O}$ próprio sistema biomédico de atendimento às urgências e emergências fornece a prova mais convincente do caráter infrutífero da empresa: ele que abriga, acolhe e faz convergir em um mesmo dispositivo - declaradamente centrado nas acepções biomédicas da urgência e da emergência - as mais variadas representações, compreensões e vivências dessas noções; até mesmo nos próprios agentes a quem abandona a triagem, dos quais não exige ao menos o conhecimento teórico-técnico da concepção da urgência que estão a servir. 



\section{Referências Bibliográficas}

ALLUÉ, X. Urgências: abierto de 0 a 24 hora-factores socioculturales en la oferta y la demanda de las urgências pediátricas. Zaragoza: Mira Editores, 1999.

ARANHA, W. Emergência e urgência. Revista Paulista de Hospitais, 23(3): 25-27, 1969.

BEAUD, S. \& WEBER, F. Guide de L'enquête de Terrain. Paris: La Découverte, 1997.

BURNET, M. G. \& GROVER, S. A. Use of the emergency department for nonurgent care during regular business hours. Canadian Medical Association Journal, 154(9): 1345-1351, 1996.

CONSEIL DE L'EUROPE. Etude comparative sur l'organisation et le fonctionnement des services d'aide médicale urgente, Strasbourg, 1990.

DELLATORRE, M. C. C. Urgência e os Serviços de Saúde. In: III CONFERÊNCIA MUNICIPAL DE SAÚDE, 1992, Santos (Mimeo.)

DELLATORRE, M. C. C. Para que Servem as Ambulâncias? In: II CONFERÊNCIA MUNICIPAL DE SAÚDE, 1993, Marília (Mimeo.)

DESLANDES, S. F. Frágeis Deuses: profissionais da emergência entre os danos da violência e a recriação da vida. Rio de Janeiro: Editora Fiocruz, 2002.

DODIER, N. \& CAMUS, A. L'hospitalité de L'hôpital: l'accueil et le tri des patients aux urgences médicales. Communications, 65: 109-119, 1997a.

DODIER, N. \& CAMUS, A., L'admission des malades - histoire et pragmatique de l'accueil à l'hôpital. Annales HSS, 4: 733-763, 1997b.

DODIER, N. \& CAMUS, A. L'intérêt pour les patients à l'entrée de l'hôpital. Enquête sociologique dans un service d'urgences médicales. Paris: rapport CERMESCSPM, 1994.

EINSENBERG, L. Disease and illness: distinction between professional and popular ideas of sickness. Culture, Medicine and Psychiatry, 1: 9-23, 1977.

FABREGA, H. Medical anthropology. Biennal Review of Anthropology, p. 167-229, 1971.

FAINZANG, S. Pour une anthropologie de la maladie en France: un regard africaniste. Paris: Editions de l'Ecole des Hautes Etudes en Sciences Sociales, 1989.

FERreirA, A. B. H. Novo Dicionário Aurélio da Língua Portuguesa. 2.ed. Rio de Janeiro: Nova Fronteira, 1986. 
FOLDES, S. S.; FISHER, L. R. \& KAMINSKY, K. What is an emergency? The judgments of two physicians. Annals of Emergency Medicine, 23(4): 833-840, 1994.

GILL, J. M. \& RILEY,A. W. Nonurgent use of hospital emergency departments: urgency from the patient's perspective. Journal of Family Practice, 42(5): 491-495, 1996.

GRUMBACH, K. \& KEANE, D. \& BINDMAN, A. Primary care and public emergency department overcrowding. American Journal of Public Health, 83(3): 372-378, 1993.

JACQUEMOT, A. Qu'est-ce qu'une urgence? Quelques réflexions sur les définitions biomédicales de l'urgence médicale. In: BARNABE, J. et al. (Orgs.) Au Visiteur Lumineux: des îles créoles aux sociétés plurielles. Mélanges offerts à Jean Benoist. Petit-Bourg: Ibis Rouge Editions, 2000.

JOSEPH, I. La Ville sans Qualités. Paris: Editions de l'Aube, 1998.

LANGDON, E. J. Cultura e os processos de saúde e doença. In: SEMINÁRIO SOBRE CULTURA, SAÚDE E DOENÇA, Londrina, Anais..., 2003.p. 91-107.

LAPLANTINE, F. Anthropologie de la Maladie. Paris: Payot, 1992.

LOPEZ, M. O sistema de atendimento das emergências médicas. In: LOPEZ, M. Emergências Médicas. 2.ed. Rio de Janeiro: Guanabara Koogan S.A., 1979.

MAGALHÃES, A. M. M. et. al. Implantação de um sistema de triagem em Unidade de Emergência. Revista do Hospital de Clinicas de Porto Alegre, 9(3): 182-187, 1989.

MARTINEZ ALMOYNA, M. Qu'est-ce donc qu'une urgence médicale? In: III SIMPÓSIO INTERNACIONAL DE ATENÇÃO PRÉ-HOSPITALAR ÀS URGÊNCIAS E TRAUMAS, 1997, Campinas (Mimeo.)

PADGET, D. K. \& BRODSKY, B. Psychological factors influencing nonurgent use of the emergency room: a review of literature and recommendations for research and improved service delivery. Social Science \& Medicine, 35: 1189-1197, 1992.

PAIM, J. S. Organização da atenção à saúde para a urgência/emergência. In: SILVA, L. M. V. (Org.) Saúde Coletiva: textos didáticos. Salvador: Centro Editorial e Didático/ Universidade Federal da Bahia, 1994.

PENEFF, J. L'hôpital en Urgence: etude par observation participante. Paris: Métailié, 1992.

PENEFF, J. Les Malades des Urgences: une forme de consommation médicale. Paris: Métailié, 2000.

ROTH, J. Some contingencies of the moral evaluation and control of clientele: the case of the hospital emergency service. American Journal of Sociology, 77(5): 839-856, 1972.

WEINERMAN, E. R. et al. Determinants of use of hospital emergency services. American Journal of Public Health, 56(7): 1037-1056, 1966. 
YOUNG, A. The anthropology of illness and sickness. Anmual Review of Anthropology, 11:257-285, 1982.

\section{Filmocrafia}

GIGLIO-JACQUEMOT, A. Urgences. DV, em cor, $59 \mathrm{mn}$, versão original em português, legendada em francês, Coprodução CAVUL/ Université de Lille 3 e A. GiglioJacquemot, Lille, juin 2002. 

Anexo 



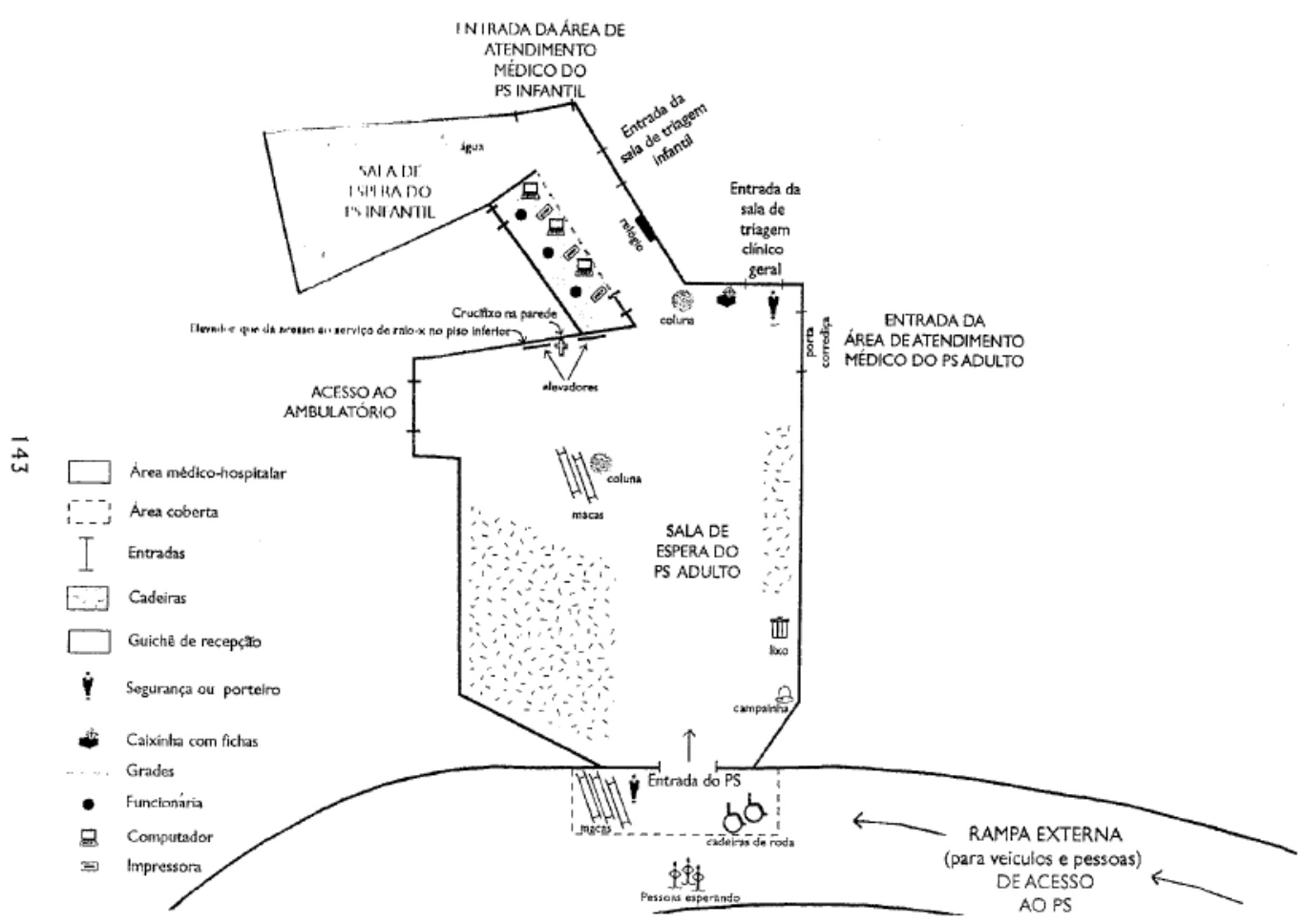

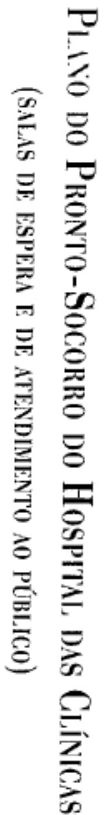


Formato: $16 \times 23 \mathrm{~cm}$

Tipologia: Times New Roman

Bauer Bodoni BT

Papel: Pólen Bold $70 \mathrm{~g} / \mathrm{m}^{2}$ (miolo)

Cartão Supremo $250 \mathrm{~g} / \mathrm{m}^{2}$ (capa)

Fotolitos: Laser vegetal (miolo)

Ace Digital Ltda. (capa)

Impressão e acabamento: Armazém das Letras Gráfica e Editora Ltda.

Rio de Janeiro, julho de 2005.

Não encontrando nossos títulos em livrarias, contactar a EDITORA FIOCRUZ:

Av. Brasil, $4036-1^{\mathrm{a}}$ andar - sala 112 - Manguinhos

21040-361 - Rio de Janeiro - RJ

Tel.: (21) 3882-9039 e 3882-9041

Telefax: (21) 3882-9006

e-mail: editora@fiocruz.br

http://www.fiocruz.br/editora 
O campo das investigaçôes antropológicas sobre a saúde e a doença tem mperimentado xápida expansão nos principais centros académicos internacionais. Liste crescimento aeontece também no Brasil, onde se verifica a consolidação de linhas de pesquisa representando as mais variadas vertentes teroricas da antropologia da saúde em programas de pós-graduação, tanto em saúde coletiva como cm antropologia. Com a coleçâo Antropologia e Saúde pretende-se contribuir para a disseminação da produçâo de alta qualidade, oriunda de centros de pesquisa e pós-graduação nacionais. Visa-se também a promover a divulgação de textos de autores estrangeiros considerados clássieos neste campo. Espera-se, com esta coleceāo, contribuir para o desenvolvimento e a divulgaçâo de referenciais teóricos e metodológicos que suscitem perspectivas inovadoras na abordagem interdisciplinar do processo saúdedoença. Fim longo prazo, Antropologia e Saíde deverá estimular um crescente diálogo entre as ciências sociais/antropologia e as eiências da saúde/saúde coletiva no Brasil. 